\title{
ECOSERV: AN EXAMINATION OF THE \\ SERVICE QUALITY EXPECTATIONS OF THE ECOTOURISTS
}

\author{
by \\ Maryam M. Khan \\ Dissertation submitted to the Faculty of the \\ Virginia Polytechnic Institute and State University \\ in partial fulfillment of the requirements for the degree of \\ DOCTOR OF PHILOSOPHY \\ in
}

Hospitality and Tourism Management

APPROVED:

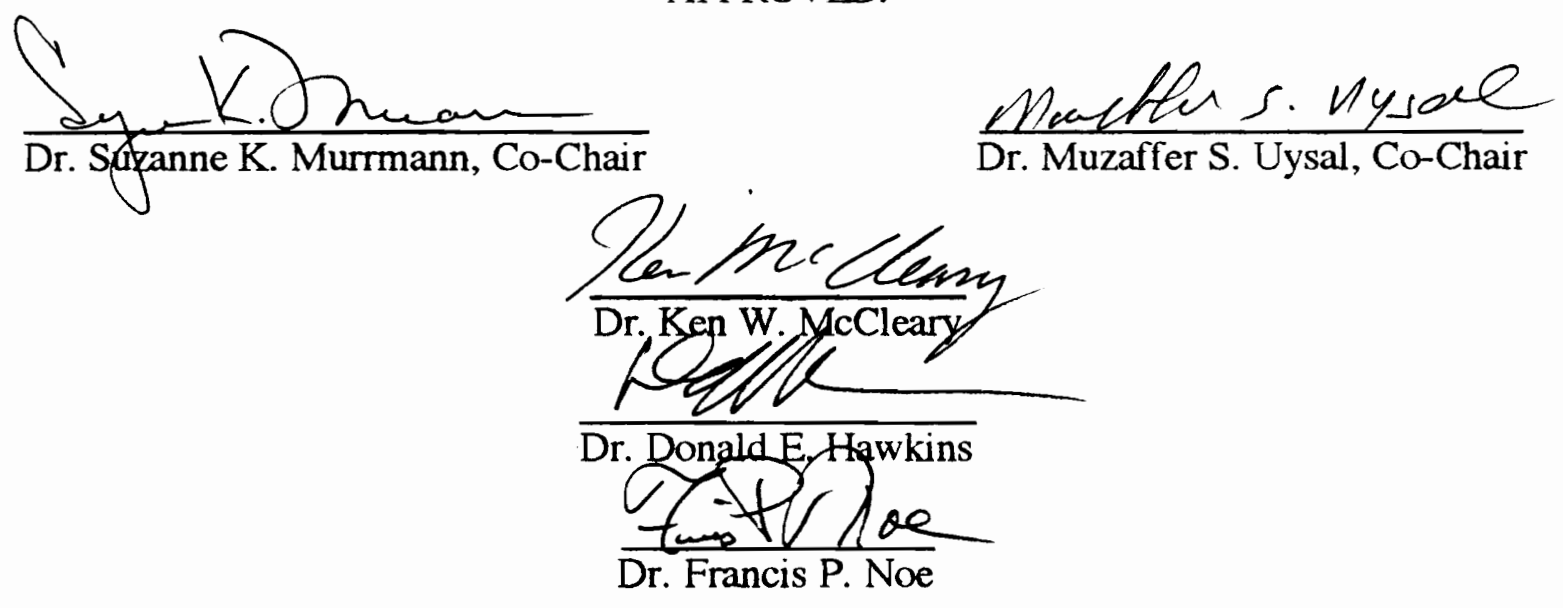

December, 1996

Blacksburg, Virginia

Keywords: Ecotourism, Service, Environment, Attitude, Behavior, Motivation 


\section{ECOSERV:}

\section{AN EXAMINATION OF SERVICE QUALITY EXPECTATIONS OF THE ECOTOURISTS}

A Ph.D. Dissertation

by

Maryam M. Khan

Hospitality and Tourism Management

Virginia Polytechnic Institute and State University December 1996 
ECOSERV: An Examination of Service Quality Expectations of the Ecotourists Maryam M. Khan

Co-Chair: Dr. Suzanne K. Murrmann Co-Chair: Dr. Muzaffer S. Uysal Hospitality and Tourism Management

(ABSTRACT)

The concept of service quality is gaining global importance in hospitality/ tourism industry, and ecotourism is regarded as one of its fastest growing segment. The main objective of this study was to examine the relationship between ecotourist's environmental attitude, environmental behavior, travel motivation, value dimension, and their service quality expectations. A conceptual model was developed to study these relationships. The service quality expectations of the ecotourists were measured by ECOSERV - an adapted version of SERVQUAL scale.

The results of the study suggest a significant relationship between service quality expectations of the ecotourists and their environmental and travel behavior. Pearson's correlation analysis revealed the direction of the relationship which supports the notion that those with positive attitude and behavior toward the environment most likely prefer services that are environmentally friendly. Also, it was evident that when reasons to travel are intercultural and social, services with local cultural influence were most likely to be expected from an ecotourist business.

Canonical correlation analysis revealed three significant variate pairs (functions). The interpretation of the first pair indicated that ecotourists who 
perceive the ecotourist business to help/benefit the community and who have an ecocentric attitude toward the environment, tend to expect more of those services that are courteous, informative, trustworthy, in addition to environmentally friendly facilities/equipment. The second pair revealed that when the attitude and behavior toward the environment is not positive, and reasons to travel are not intercultural, services are expected to be performed on promised time, with prompt personal and individual attention. The third pair suggested that when there is no interest in intercultural social interactions but there is an ecocentric attitude toward the environment, the service preference tend to be for facilities that are safe/appropriate to the environment, and equipment that minimize environmental degradation. Also, it was evident that service quality expectations of the ecotourists are somewhat influenced by their attitude toward the environment, their behavior patterns, reasons to travel, and emphasis on value.

The study contributed to the theoretical and methodological advancement of service quality and ecotourism literature by developing ECOSERV, a scale to measure the service quality expectations of the ecotourists. It provided practical and marketing implications for the ecotourist industry which can be useful to the ecotourist marketers, tour operators and destination promoters, to target specific markets, design products and services, plan communication strategies, and promote tourism that is sustainable. 


\section{ACKNOWLEDGMENT}

First of all I would like to express my humble gratitude to Almighty for providing me this opportunity to complete doctoral studies.

There are a number of people who I wish to acknowledge for their contribution to this study. I would like to express my sincere thanks to Dr. Suzanne Murrmann and Dr. Muzaffer Uysal for their guidance and support in completion of this dissertation. Also thanks to Dr. Ken McCleary for his advice and support throughout my studies. I am indebted to Dr. Don Hawkins for his continuos support and encouragement as well as for introducing me to the ecotourism industry. Thanks to Dr. Frank Noe for his advice and guidance.

Special thanks to Dean S. J. Ritchey for encouraging and providing me the opportunity to study at Virginia Tech. My sincere gratitude to seven tour operators who provided me with the mailing lists, without which this research would not have been possible. Also my appreciation to those companies who provided prizes for the lottery drawing. Thanks to Mr. Stanley Selangut for providing seven day stay at Maho Bay Resort for the lottery winners.

Last but not the least I would like to convey my love and wishes to my family especially my children, Samala, Feras, and Nufayl, for their patience, understanding, and continuos encouragement during this long ordeal. 


\section{TABLE OF CONTENTS}

\begin{tabular}{lccccccccr} 
& & & & & & & & & \multicolumn{2}{c}{ Page } \\
ABSTRACT $\ldots$ & $\ldots$ & $\ldots$ & $\ldots$ & $\ldots$ & $\ldots$ & $\ldots$ & $\ldots$ & $\ldots$ & ii \\
ACKNOWLEDGMENTS & $\ldots$ & $\ldots$ & $\ldots$ & $\ldots$ & $\ldots$ & $\ldots$ & $\ldots$ & iv \\
TABLE OF CONTENTS & $\ldots$ & $\ldots$ & $\ldots$ & $\ldots$ & $\ldots$ & $\ldots$ & $\ldots$ & v \\
LIST OF TABLES & $\ldots$ & $\ldots$ & $\ldots$ & $\ldots$ & $\ldots$ & $\ldots$ & $\ldots$ & $\ldots$ & viii \\
LIST OF FIGURE & $\ldots$ & $\ldots$ & $\ldots$ & $\ldots$ & $\ldots$ & $\ldots$ & $\ldots$ & $\ldots$ & x
\end{tabular}

\section{CHAPTER I. OVERVIEW OF THE STUDY}

Introduction ...

Tourism and Concerns for the Environment $\quad \ldots \quad$ f

$\begin{array}{llllllll}\text { Growth of Sustainable Tourism } & \ldots & \ldots & \ldots & \ldots & \ldots & 3\end{array}$

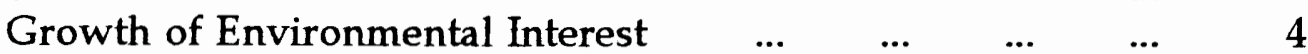

Growth of Ecotourism

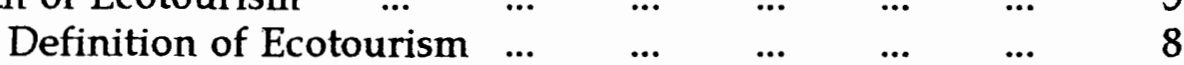

$\begin{array}{lllllll}\text { Studies of Ecotourism } & \ldots & \ldots & \ldots & \ldots & \ldots & 11\end{array}$

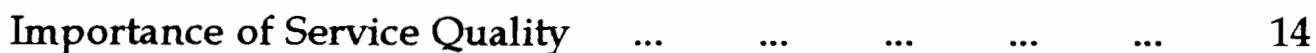

$\begin{array}{lllllllll}\text { Objective of the Study } & \ldots & \ldots & \ldots & \ldots & \ldots & \ldots & 17\end{array}$

$\begin{array}{llllllll}\text { Problem Statement } & \ldots & \ldots & \ldots & \ldots & \ldots & \ldots & 18\end{array}$

$\begin{array}{lllllllll}\text { Organization of the Study } \ldots & \ldots & \ldots & \ldots & \ldots & \ldots & 19\end{array}$

$\begin{array}{llllllllll}\text { Definitions } & \ldots & \ldots & \ldots & \ldots & \ldots & \ldots & \ldots & \ldots & 20\end{array}$

$\begin{array}{llllllllll}\text { Summary } & \ldots & \ldots & \ldots & \ldots & \ldots & \ldots & \ldots & \ldots & 22\end{array}$

\section{CHAPTER II. REVIEW OF RELATED LITERATURE}

$\begin{array}{lllllllll}\text { Introduction } \ldots & \ldots & \ldots & \ldots & \ldots & \ldots & \ldots & \ldots & 23\end{array}$

$\begin{array}{lllllllll}\text { Service Quality } & \ldots & \ldots & \ldots & \ldots & \ldots & \ldots & \ldots & 23\end{array}$

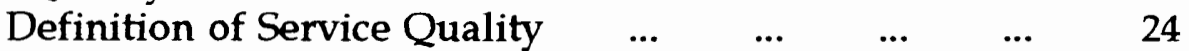

$\begin{array}{llllll}\text { SERVQUAL and its Application } & \ldots & \ldots & \ldots & \ldots & 26\end{array}$

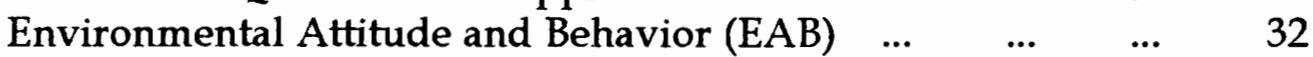

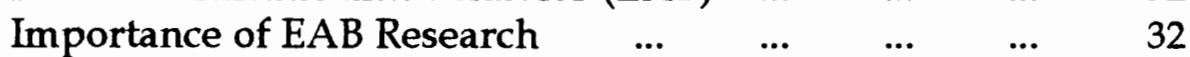

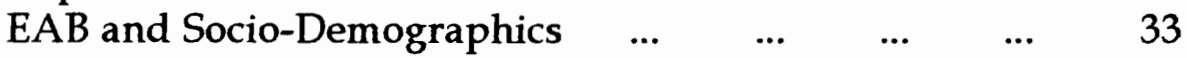

$\begin{array}{lllll}\text { Environmental Attitude and NEP } & \ldots & \ldots & \ldots & 37\end{array}$

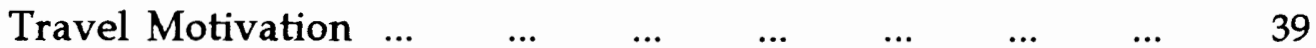

$\begin{array}{lllllll}\text { Definition of Motive } & \ldots & \ldots & \ldots & \ldots & \ldots & 39\end{array}$

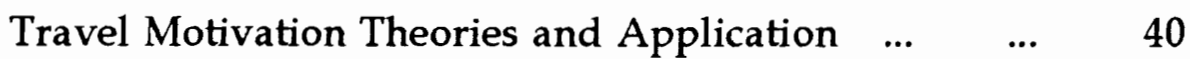

Social Psychological Motivation Theory $\quad$... $\quad \ldots . \quad 42$

Attraction and Social Motivation of Ecotourists $\quad \ldots \quad 45$

$\begin{array}{lllllllll}\text { Value Dimension } & \ldots & \ldots & \ldots & \ldots & \ldots & \ldots & \ldots & 47\end{array}$

$\begin{array}{llllllll}\text { Travel Characteristics } & \ldots & \ldots & \ldots & \ldots & \ldots & \ldots & 49\end{array}$

$\begin{array}{llllllllll}\text { Summary } & \ldots & \ldots & \ldots & \ldots & \ldots & \ldots & \ldots & \ldots & 50\end{array}$ 
$\begin{array}{lllllllll}\text { Introduction } \ldots & \ldots & \ldots & \ldots & \ldots & \ldots & \ldots & \ldots & 53\end{array}$

$\begin{array}{llllllll}\text { Research Framework } & \ldots & \ldots & \ldots & \ldots & \ldots & \ldots & 53\end{array}$

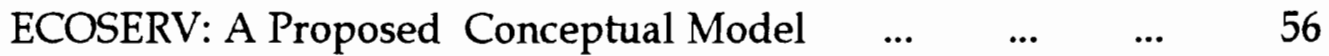

$\begin{array}{llllllll}\text { Research Hypotheses } & \ldots & \ldots & \ldots & \ldots & \ldots & \ldots & 61\end{array}$

$\begin{array}{llllllll}\text { Design of the Study ... } & \ldots & \ldots & \ldots & \ldots & \ldots & \ldots & 62\end{array}$

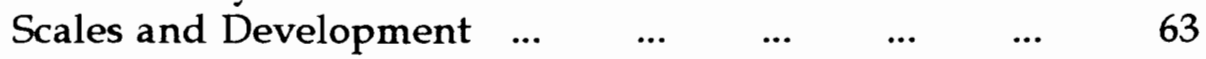

$\begin{array}{lllllllll}\text { Pilot Study } & \ldots & \ldots & \ldots & \ldots & \ldots & \ldots & \ldots & 78\end{array}$

$\begin{array}{lllllll}\text { Population and Sample } & \ldots & \ldots & \ldots & \ldots & \ldots & 80\end{array}$

$\begin{array}{lllllll}\text { Research Procedures } & \ldots & \ldots & \ldots & \ldots & \ldots & 81\end{array}$

$\begin{array}{llllllll}\text { Non-Response Bias ... } & \ldots & \ldots & \ldots & \ldots & \ldots & \ldots & 82\end{array}$

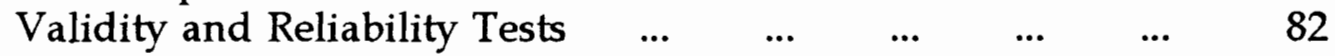

$\begin{array}{lllllllll}\text { Analyses of Data } & \ldots & \ldots & \ldots & \ldots & \ldots & \ldots & \ldots & 83\end{array}$

$\begin{array}{llllllllll}\text { Summary } & \ldots & \ldots & \ldots & \ldots & \ldots & \ldots & \ldots & \ldots & 88\end{array}$

CHAPTER IV. RESULTS AND DISCUSSION

$\begin{array}{lllllllll}\text { Introduction } \ldots & \ldots & \ldots & \ldots & \ldots & \ldots & \ldots & \ldots & 89\end{array}$

$\begin{array}{lllllllll}\text { Data Collected } & \ldots & \ldots & \ldots & \ldots & \ldots & \ldots & \ldots & 89\end{array}$

$\begin{array}{llllllll}\text { Profile of Respondents } & \ldots & \ldots & \ldots & \ldots & \ldots & \ldots & 90\end{array}$

$\begin{array}{llllllll}\text { Non-Response Bias ... } & \ldots & \ldots & \ldots & \ldots & \ldots & \ldots & 109\end{array}$

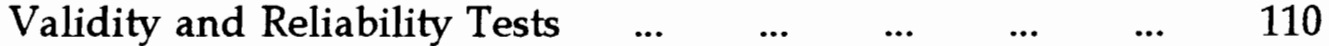

$\begin{array}{lllllllll}\text { Factor Analysis } & \ldots & \ldots & \ldots & \ldots & \ldots & \ldots & \ldots & 113\end{array}$

$\begin{array}{llllllll}\text { Hypotheses Testing... } & \ldots & \ldots & \ldots & \ldots & \ldots & \ldots & 124\end{array}$

$\begin{array}{llllllllll}\text { Summary } & \ldots & \ldots & \ldots & \ldots & \ldots & \ldots & \ldots & \ldots & 155\end{array}$

\section{CHAPTER V. SUMMARY AND CONCLUSION}

$\begin{array}{lllllllll}\text { Introduction } \ldots & \ldots & \ldots & \ldots & \ldots & \ldots & \ldots & \ldots & 156\end{array}$

$\begin{array}{llllllll}\text { Findings of the Study } & \ldots & \ldots & \ldots & \ldots & \ldots & \ldots & 156\end{array}$

$\begin{array}{llllllll}\text { Significant Findings } & \ldots & \ldots & \ldots & \ldots & \ldots & \ldots & 162\end{array}$

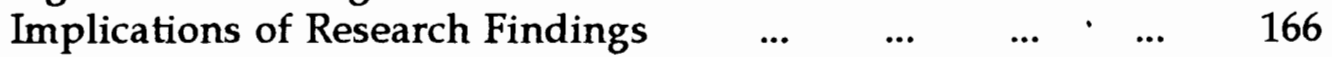

$\begin{array}{lllllll}\text { Contribution of the Study } \ldots & \ldots & \ldots & \ldots & \ldots & \ldots & 170\end{array}$

$\begin{array}{llllllll}\text { Limitations of the Study } & \ldots & \ldots & \ldots & \ldots & \ldots & \ldots & 176\end{array}$

$\begin{array}{llllll}\text { Recommendation for Future Research } & \ldots & \ldots & \ldots & \ldots & 177\end{array}$

$\begin{array}{llllllllll}\text { Conclusion } & \ldots & \ldots & \ldots & \ldots & \ldots & \ldots & \ldots & \ldots & 179\end{array}$

$\begin{array}{llllllllll}\text { BIBLIOGRAPHY } & \ldots & \ldots & \ldots & \ldots & \ldots & \ldots & \ldots & \ldots & 181\end{array}$ 


\section{APPENDICES}

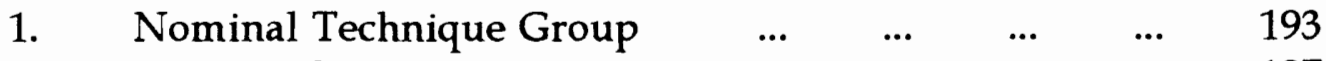

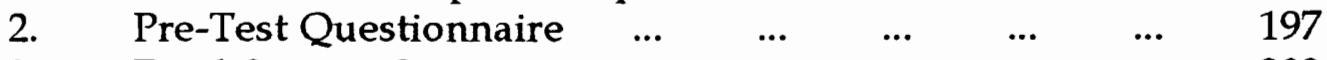

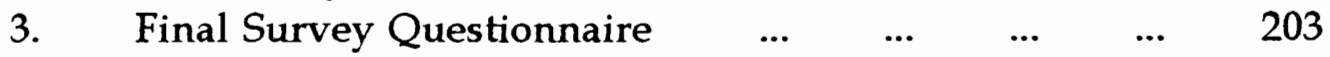

4. Cover Letter, Envelope and Lottery Coupons ... $\quad \ldots \quad 216$

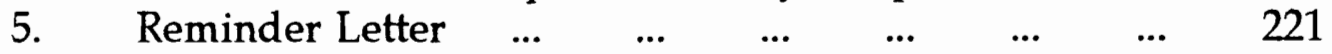

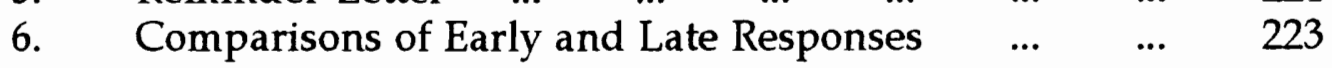

$\begin{array}{lllllllllll}\text { VITA } \ldots & \ldots & \ldots & \ldots & \ldots & \ldots & \ldots & \ldots & \ldots & \ldots & 225\end{array}$ 


\section{LIST OF TABLES}

Page

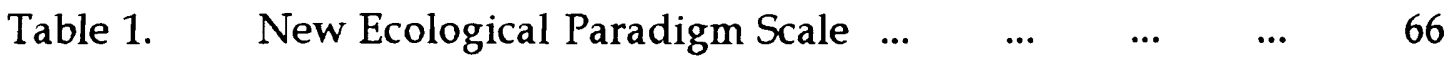

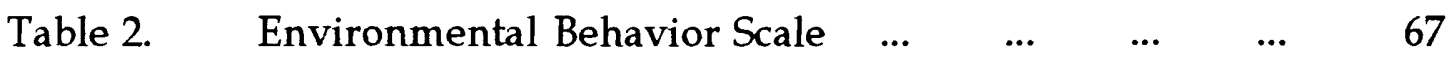

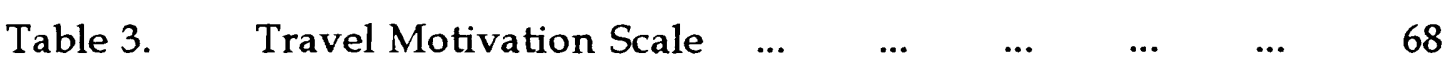

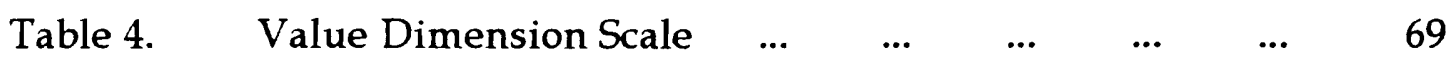

Table 5. Service Quality Expectation Scales:

$\begin{array}{lllllll}\text { A Comparison } & \ldots & \ldots & \ldots & \ldots & \ldots & 74\end{array}$

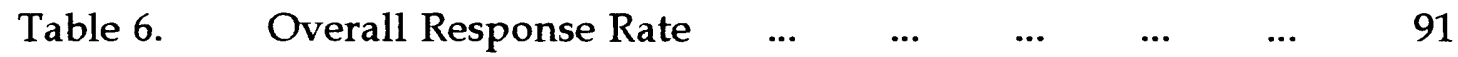

$\begin{array}{llllll}\text { Table 7. Demographic Profile of Ecotourists } & \ldots & \ldots & \ldots & 92\end{array}$

$\begin{array}{llllllll}\text { Table 8. Geographic Distribution } & \ldots & \ldots & \ldots & \ldots & \ldots & 96\end{array}$

$\begin{array}{llllllll}\text { Table 9. } & \text { Travel Characteristics } & \ldots & \ldots & \ldots & \ldots & \ldots & 98\end{array}$

Table 10. Descriptive Analysis of Environmental Attitude $\quad \ldots \quad 101$

Table 11. Descriptive Analysis of Environmental Behavior $\quad \ldots \quad 102$

Table 12. Descriptive Analysis of Travel Motivations $\quad \ldots \quad \ldots \quad 104$

$\begin{array}{lllll}\text { Table 13. Descriptive Analysis of Value Dimension } & \ldots & \ldots & 105\end{array}$

Table 14. Descriptive Analysis of ECOSERV:

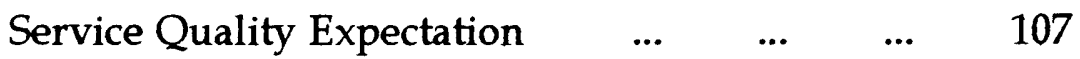

$\begin{array}{llllllll}\text { Table } 15 . & \text { Reliability Coefficient } & \ldots & \ldots & \ldots & \ldots & \ldots & 112\end{array}$

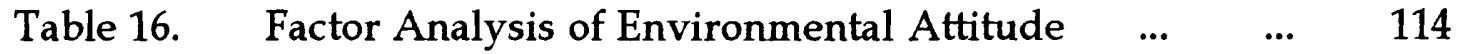

$\begin{array}{llllll}\text { Table 17. } & \text { Factor Analysis of Environmental Behavior } & \ldots & \ldots & 117\end{array}$

$\begin{array}{llllll}\text { Table 18. Factor Analysis of Travel Motivation } & \ldots & \ldots & \ldots & 118\end{array}$

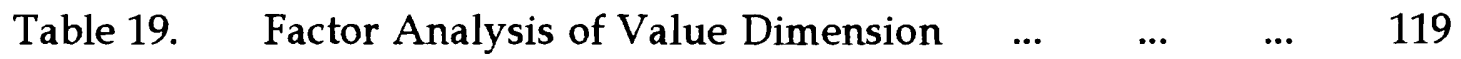

Table 20. Factor Analysis of ECOSERV:

$\begin{array}{llllll}\text { Service Quality Expectation } & \ldots & \ldots & \ldots & \ldots & 122\end{array}$

Table 21. Correlation Coefficient Analysis: Attitude $\quad \ldots \quad \ldots \quad \ldots \quad 126$

$\begin{array}{lllll}\text { Table 22. Correlation Coefficient Analysis: Behavior } & \ldots & \ldots & 129\end{array}$

Table 23. Correlation Coefficient Analysis: Motivation ... $\quad \ldots \quad 132$ 


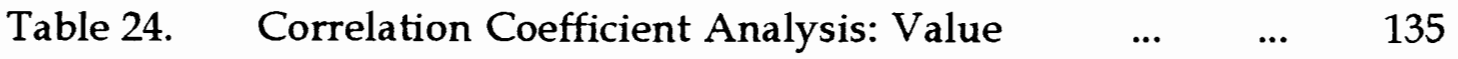

$\begin{array}{lllll}\text { Table 25. Canonical Correlation Analysis: results } & \ldots & \ldots & 141\end{array}$

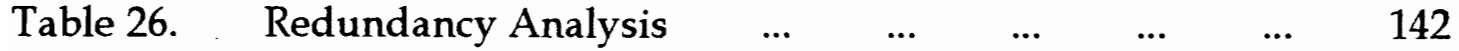

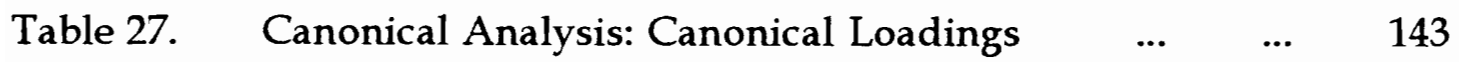

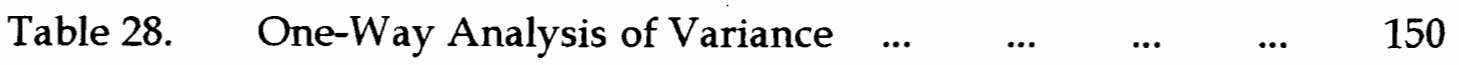

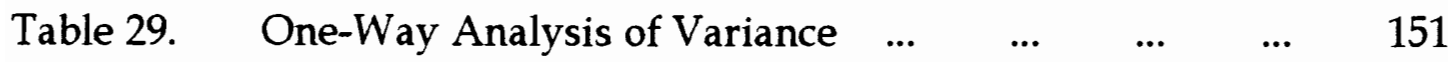

$\begin{array}{lllllllll}\text { Table 30. } & \text { T-Test Analysis } & \ldots & \ldots & \ldots & \ldots & \ldots & \ldots & 152\end{array}$ 


\section{LIST OF FIGURES}

Page

Figure 1. ECOSERV:

A Proposed Model for Service Quality expectations ...

57 


\section{CHAPTER ONE \\ OVERVIEW OF THE STUDY}

\section{INTRODUCTION}

The primary purpose of this study was to empirically determine the relationship between ecotourist's environmental attitude, environmental behavior, travel motivation, value dimension, travel characteristics and their service quality expectations. This chapter provides an introduction and justification for the research effort undertaken. It includes a brief discussion of the growing importance of ecotourism and service quality, followed by the problem statement and objectives of the study.

\section{TOURISM AND CONCERNS FOR THE ENVIRONMENT}

Global environmental concerns and interest in saving the planet have perhaps galvanized consumers, researchers, tourism planners, politicians and the general public to be increasingly sensitive to the environment. In the last two decades a wide range of literature relating to environmental impacts and tourism development has emerged. Tourism planners are looking toward new policies, new concepts, and new management principles that integrate sustainable development (Gunn, 1994). They are beginning to realise that the environment is a finite resource, and in order to provide high environmental quality to the tourists, sound planning is necessary (Inskeep, 1991). The 
tourism industry is under scrutiny both from public and internally, as to how it should address and meet the criteria of sustainable development. The need for sustainable tourism development is gaining popularity and well-planned "ecotourism" is being recognized by many as one of the tools for sustainable tourism development (Wight, 1993b; Boo, 1992; Whelan, 1991).

The tourism industry has become a global industry, serving over 500 million consumers per year, and this number is expected to reach 661 million by the year 2000 [World Travel and Tourism Council (WTTC), 1995]. It provides employment to over two hundred million workers worldwide - one in every nine workers - it contributes over ten percent of global investment and eleven percent of worldwide consumer spending. These economic figures place tourism as an international activity of importance and significance. For many countries tourism is the largest commodity in international trade, and for many others it ranks among the top three industries (McIntosh, Goeldner, and Ritchie, 1995). In addition to numerous benefits, tourism also generates noneconomic costs to host communities, such as inappropriate development creating environmental damage.

Associated with its economic benefits are the socio-cultural and environmental impacts of tourism. The most evident impact that has received considerable attention in the last decade is the negative environmental impact. 
According to Trigano (1984), tourism and the environment are often inseparable, since the environment is the raw material on which tourism depends. The relationship between tourism and the environment is complex giving rise to a wide range of environmental impacts (Pearce, 1985; Inskeep, 1991). Its effect on traffic, air, noise, water, congestion, depletion of natural resources and its impact on the environment have been reported quite extensively in the past few years by several researchers (Mathieson and Wall, 1982; Pearce, 1985 and 1981; Liu and Var, 1986; Farrell and McLelland, 1987; Milni, 1989; Long, Perdue and Allen, 1990; Milman and Pizam, 1988; Caneday and Zeiger, 1991; Dowling, 1994). The dilemma facing the tourism industry is that while it is hard to deny the economic benefits of tourism, it is becoming equally hard to ignore the need for protection and conservation of the natural resources which are essential for tourism to survive. According to McKercher (1993), the natural link between tourism and the environment provides an obvious self-interest for tourism to protect its environment.

\section{GROWTH OF SUSTAINABLE TOURISM}

In order to address the environmental issues and to set out a global strategy, the Brundtland Report (WTTC, 1987), defined sustainable development as "meeting the needs of the present without compromising the ability of future generations to meet their own needs." The Canadian government sponsored the "Globe 90 " conference that defined sustainable 
tourism development as "leading to management of all resources in such a way that we can fulfill economic, social, and aesthetic needs while maintaining cultural integrity, essential ecological processes, biological diversity, and life support systems." Ecotourism, as one of the current expressions of sustainable tourism implies that resource protection and tourism development can be compatible (Gunn, 1994; Khan and Hawkins, 1995). According to Lindberg and Huber (1993), ecotourism provides an impetus to expand both conservation and tourism development. While Budowski's (1976) “Tourism and conservation: conflict, coexistence or symbiosis," suggested it was possible to integrate the concept of tourism development and conservation.

\section{GROWTH OF ENVIRONMENTAL INTEREST}

The past two decades have demonstrated that the environmental movement has entered the mainstream of global lifestyle. According to Dunlap and Scarce (1991), the success of Earth Day 1990 indicates that the environmental movement is not only alive and well after two decades but is stronger than ever before. They further stated that a growing majority support government action to protect environmental quality and many prefer environmental protection over economic growth. The Earth Submit in Rio de Janeiro, further emphasized the importance of the environment which is evident from this concluding statement: "we have reached a critical moment in history where we must balance environment responsibility with economic 
viability if we are to sustain growth while maintaining a livable planet (Burr, 1991)." Eighty five percent of the industrialized world's citizens believe that environment is the number one public issue, while 76 percent of Americans consider themselves environmentalists (Carson and Moulden, 1991). The number of environmental groups as well as the number of dues paying environmentalists in the United States is at an all time high. In a 1990 report by the Roper Organization environmental issues were rated fourth on priority list after crime and drugs, AIDS, and health costs.

\section{GROWTH OF ECOTOURISM}

There is a growing interest in the environment as evident in the rapidly expanding literature on forms of tourism variously labeled "green" "eco" "nature" or "alternative" (Ziffer, 1989; Boo, 1990; Eagles, 1992). Nature-based tourists according to Vickerman (1988) spend $\$ 14$ billion annually. The World Tourism Organization reported that nature travel has increased 15 percent a year since 1990. And within the tourism industry there is a shift in the way people vacation (Boo, 1992). Demand for adventurous, participatory, and nature-oriented tourism is growing. Travelers are interested in learning firsthand about ecosystems, endangered species, and complex conservation issues such as deforestation. They are seeking experiences that are both educational and enjoyable. They are expecting and demanding a high level of environmental quality in tourism areas. They feel a need to "get back in touch 
with nature" before it is too late (Whelan, 1991). In a study conducted by the National Tour Association (1991), mature adults showed a strong concern for protecting the environment (94\%), and were asking the tour companies what they were doing to protect the environment. They were looking more toward environmentally sensitive and responsible travel experience.

In a study to evaluate consumer's intention to stay in a hotel, Gustin and Weaver (1996) reported that businesses today are operating in an environmental conscious society. Seventy-three percent of the respondents consider themselves to be environmentally-minded consumers. It was concluded that the consumers in general have a positive attitude toward the environment, and seventy-one percent of the respondents said they would be likely to stay in a hotel that implement environmentally friendly strategies. According to Khan (1995), in order to attract the environmentally conscious consumers, many lodging facilities are incorporating policies and procedures that are environmentally friendly. In this study thirteen measures were identified, which includes practices such as: energy and water conservation; recycling, reducing and reusing; educating hosts/guests about environmental issues; and marketing green meetings. It was concluded that after initial investment of time and resources, these practices give hotels a competitive edge and is beneficial in terms of returns. Interest in the environment has 
fostered an important market segment that is seeking facilities that are environmentally friendly .

Travelers from Australia, Japan, Europe and North America in particular are increasingly placing importance on the quality of the natural and cultural environment of their vacation destinations (Frangialli, 1992; Moore and Carter, 1993). Pearce and Wilson (1995), reported that international tourists to New Zealand are more interested in natural attractions and the environment. In a study conducted by Hui (1990), sixty percent of Australian travelers fall within an "anti-tourist" segment seeking natural and cultural areas. It is apparent that the travelers/consumers in general are seeking experience in the natural environment..

The above literature demonstrate that consumers in general are becoming environmentally conscious, looking for natural and educational experiences and seeking businesses that implement strategies that are environmentally positive. With the consumers going green (ecologically aware) combined with the need for sustainable tourism development it is not surprising that ecotourism is on the rise. It has been reported that 8 million adult US travelers have taken an ecotrip, and thirty five million are likely to take an ecotrip in the next three years. The potential ecotourism market is 43 million according to a study conducted by the United States Travel Data Center 
(1991). It is estimated that ecotourism arrivals will grow 10-15 percent annually.

The market segment for ecotourism is high social status. It involves mostly affluent and highly educated people traveling from developed countries to developing countries to seek natural and cultural/educational experience. Travel to the Galapagos islands increased by an average of 20 percent from 1987 to 1990; the number of trekkers to Nepalese Himalayas grew by 25 percent from 1985 to 1988; Belize experienced a 55 percent increase in tourists arrivals from 1980 to $1990 ; 60$ percent of visitors to Costa Rica are interested in visiting national areas; and Kenya and Maldives doubled their number of arrivals over the past decade (Cater, 1993; Boo, 1990).

\section{Definition of Ecotourism}

Ecotourism according to Wight (1993a) has become a topic of great interest in the tourism literature. To some it is nature tourism, alternative tourism, cultural tourism, soft tourism, adventure tourism, responsible tourism or green tourism. It is described as a product, a destination or an experience. There is not yet a consistently used definition of ecotourism, in part owing to the many stakeholders involved in ecotourism who bring their own perspectives and motivations. According to Boo (1992), ecotourism is a new idea that has captured the attention of many stakeholders including protected 
area managers, conservationists, rural development specialists, government officials, tourism planners, travel writers, and many more. Orams (1995) reviewed a wide variety of ecotourism definitions and presented them on a continuum. On one side the ecotourist experience shifts from simple enjoyment and satisfaction to greater understanding, attitudinal change and finally more environmentally responsible behavior. Ballantine and Eagles (1994), tried to define Canadian ecotourists by proposing a set of three criteria that can be used to define ecotourists namely: a social motive (traveling to learn about nature), a site attraction motive (visiting wilderness or undisturbed areas) and time commitment (at least $33 \%$ of the trip). A select list is reported to illustrste the various connotations of the term. As listed:

1. The Ecotourism Society (1992) defines ecotourism as "a purposeful travel to natural areas to understand the culture and natural history of the environment, taking care not to alter the integrity of the ecosystem, while producing economic opportunities that make the conservation of the natural resources beneficial to local people."

2. The Canadian Environmental Advisory Council (Wight, 1993a) defined ecotourism as "an enlightening nature travel experience that contributes to conservation of ecosystem, while respecting the integrity of the host communities." 
3. Ryel and Grasse (1991) define ecotourism as "a purposeful travel that creates an understanding of cultural and natural history, while safeguarding the integrity of ecosystem and producing economic benefits that encourages conservation."

4. According to Valentine (1993), "ecotourism is restricted to that kind of tourism which is :

* based on relatively undisturbed natural areas;

* non-damaging, non-degrading, and ecologically sustainable;

* a direct contributor to the continued protection and management of the natural areas used;

* subject to an adequate and appropriate management regime."

5. Boo (1992) defines "ecotourism as a nature travel that advances conservation and sustainable development."

Based on the various definitions of ecotourism it can be concluded that ecotourism is purposeful travel to a natural environment to interact, learn, and experience other cultures, and to economically help local communities that work toward conservation and preservation of the ecosystem. It should be noted that ecosystem includes the natural environment, the flora and fauna, the wildlife, and indigenous communities of an area. 


\section{Studies of Ecotourism}

Ecotourism is expected to intensify toward the year 2000 as issues related to the natural environment and ecologically conscious tourists continue to grow (Moore and Carter, 1993). Compared to the worldwide growth of ecotourism and its promising potential, there are limited number of studies that report empirical findings. Most of the studies about ecotourism are qualitative or descriptive in nature and are focused on the supply factors of ecotourism namely destinations and management practices, with limited emphasis on the demand factors of ecotourism, namely ecotourists.

Ruschmann (1992) reported on the ecological tourism in Brazil and emphasized the practice of monitoring the ecological tourism infrastructure to avoid environmental degradation. Hall and McArthur (1993), discussed the ecotourism activity in Antarctica and sub-Antarctica islands, and the development of an appropriate management regime for sustainable development. Ayala (1995) proposed planning, design, and management approaches for an international ecotourism destination in the archipelago of Fiji. Moore and Carter (1993), examined the tourism trends in Australia and concluded that growth of ecotourism requires necessary changes in priorities of natural resource management and ecotourism operators. Blangy and Nielsen (1993), while emphasizing ecotourism and minimum impact policy propose eight strategies for minimizing the impact of tourism on environment. Sanson 
(1994), analyzed the development of tourism policy and management to ensure the protection of natural conservation values in Sub-Antarctic islands. Lindberg and Hawkins (1993) edited "Ecotourism: A Guide for Planners and Managers," with state-of-the art planning and management approaches for effective ecotourism projects.

The limited number of ecotourist market studies that have been published relate to travelers visiting a specific destination from one country of origin (Boo, 1990; Fennell and Smale, 1992; Eagles, 1992; Ballantine and Eagles, 1994; Eagles and Cascagnette, 1995). Most of these studies are narrow and limited in scope, and not central to the basic purpose of ecotourism. Therefore, in order to fully understand and comprehend the ecotourism phenomenon, studies relating to the ecotourist market are very important. Studies investigating the demographic and psychographic characteristics, environmental attitude and behavior, and service needs of the ecotourist will help the tourism planner or marketer to better understand this growing market segment and plan effectively for future. Though the demand for natural area tourism is rising worldwide, few statistics exist on the profile of tourists traveling to natural environments, and there are gaps in the information necessary to manage (Boo, 1990) and promote ecotourism effectively. 
The tourists' market has been segmented on the demographic and pyschographic characteristics of tourists. Such a type of information about the ecotourists will provide a better insight as to why ecotourists do what they do and what they expect from the service provider. In addition, with consumers becoming increasingly ecologically conscious, it will be important to analyze the environmental attitude and behavior patterns of the ecotourists. However, with limited systematic analyses of ecotourism demand factors, marketing decisions are largely based on experience and intuitive judgment by those familiar with the industry (Lindberg and Huber, Jr. 1993; Ryel and Grasse, 1991).

The widespread growth of ecotourism is likely to continue, attracting travelers from around the globe. Ecotourists' service provider can no longer be able to successfully manage or attract the ecotourist based on experience or intuition. Ecotourists will seek and choose destinations and services that satisfy their expectations. In order to continually and fully satisfy the growing ecotourist market, an in-depth analysis into the demographic and the psychographic characteristics of ecotourists including their service quality expectations is important. 


\section{IMPORTANCE OF SERVICE QUALITY}

Tourism businesses are service-oriented, and service oriented businesses are different from product oriented businesses (Fridgen 1990). Tourism services are usually intangible and as such, difficult for the customer to recognize immediately. The customer usually comes to a location where the service is offered and instead of taking the product home he/she interacts with the service provider. Tourism is essentially service, success is based on the quality of the service (Calantone and Mazanec, 1991).

The concept of service and service quality is gaining attention in the marketing literature. The definition of service quality and its attributes might be "disputed," but its overall importance to market share and return on investment have been adequately documented (Anderson and Zeithaml, 1984). Service involves the consistent satisfaction of the needs and expectations of all customers. Service is a social experience that take place in a cultural context, it involves an encounter between the customer and the service providers. A level of satisfaction is supposedly achieved if the needs are met or exceeded by the providers (Shames and Glover, 1989).

Service is experienced by the customer psychologically as well as physically (Murrmann and Suttle, 1993). In order to fully comprehend service quality, service characteristics need to be analyzed. Intangibility, 
inseparability of production and consumption, heterogeneity, and perishability that are consistently cited in the service marketing literature (Rathmell, 1974; Shostack, 1977; Berry, 1980; Lovelock, 1981).

Most services are intangible (Bateson, 1977; Berry, 1980; Lovelock, 1981; Shostack, 1977). They cannot be seen, touched, or tasted since they are performances rather than objects. It is hard to count, measure, inventory, or test them because of intangibility. Since services are labor intensive, they are heterogeneous in nature. No two service experiences are exactly alike (Murrmann and Suttle, 1993), they often vary from customer to customer, place to place, provider to provider, and day to day. Although heterogeneity is not always negative it is unpredictable and limits the organization's ability to deliver a consistent service experience to the customer.

Service is also characterized by its simultaneous production and consumption, giving many services the attribute of inseparability. Since services are first sold, then produced and consumed, the customer and the service provider is often engaged in close, personal encounters. In many labor intensive services such as hospitality and tourism, the quality of service delivery occurs during such encounters. Service experience starts from the time the customer enters the facility to the time he/she departs. Hence the decor, the ambiance, the sound and smell, the timeliness of service delivery, the 
provider's attitude and other attributes accompanying service delivery will impact the overall evaluation of the service experience by the customer.

Services, due to their temporal nature are often perishable. The value of a room or a seat in a safari van is lost if not sold for that day. Like an object it cannot be stored and sold on another day as might be the case with a coat or a car. Finally, many services in some manner or the other, require customer participation. Food service operations such as fast foods and cafeterias; quick check outs at hotels; guest carrying their own luggage; and guests' participation in recycling efforts expect customers to perform "self service."

Intense global competition will require businesses to position themselves favorably to satisfy today's demanding customer. Providing high quality "world class" service has become a crucial factor in the success of any hospitality firm (Khan and Murrmann, 1995). To respond effectively, service providers must acquire more sophisticated methods of determining travelers' service expectations and design packages accordingly. One can no longer assume that all tourists (mass and eco) are the same and that their behavior, attitude, psychological needs, and expectations require no separate inquiry. However, with the growth and future potential of ecotourism little progress has been made to understand this growing market segment. According to Calantone and Mazanec (1991), a logical way for the tourism manager to 
improve his/her decision regarding consumers, is to investigate consumer needs, behavior and attitude.

\section{OBJECTIVE OF THE STUDY}

Considering the significance and growth of ecotourism and the importance given to service quality in todays' global market place, combined with the need for a demographic and pyschographic profile of ecotourists, this study was planned. The primary objective of this study sought to empirically determine the relationship between ecotourist's environmental attitude, environmental behavior, travel motivation, value dimension, travel characteristics and their service quality expectations. Specific objectives were:

1. To profile ecotourists' demographics (e.g. age, education, family status, income, etc.) and travel characteristics (trip type, travel group, accommodation, expenses, etc.)

2. To examine the relationship between ecotourists' environmental attitude, environmental behavior, travel motivation, value dimension and their service quality expectations. 
3. To examine the effects of selected travel characteristics on service quality expectations of the ecotourists by using one-way analysis of variance and t-tests.

\section{PROBLEM STATEMENT}

This section presents six problem statements to be tested in the study.

1. Is ecotourists' environmental attitude associated with ecotourists' service quality expectations?

2. Is ecotourists' environmental behavior associated with ecotourists' service quality expectations?

3. Are ecotourists' travel motivations associated with ecotourists' service quality expectations?

4. Is ecotourists' value dimension associated with ecotourists' service quality expectations?

5. Are ecotourists' environmental attitude, environmental behavior, travel motivation and value dimension collectively associated with ecotourists' service quality expectations? 
6. Are ecotourists' travel characteristics associated with ecotourists' service quality expectations?

\section{ORGANIZATION OF THE STUDY}

Chapter one presents the introduction and justification of the study followed by the objective of the study and problem statement. It emphasizes the growth and potential of ecotourism and the importance given to service quality in global competitive market place.

Chapter two provides the literature review related to service quality; environmental attitude, environmental behavior, travel motivations, value dimension and travel characteristics. Previous studies relevant to this study are reviewed.

Chapter three presents and discusses the proposed conceptual model that is used in the study. It also presents the research hypotheses, scale and development, survey instrument, population and sample, pilot study, and data of analysis.

Chapter four presents the results of hypotheses testing and provides a discussion of the results. 
Chapter five presents the findings from the data analyses and the recommendations emerging from this study. It also discusses the contribution of the study, its limitations, its implications and future research recommendation.

\section{DEFINITIONS}

Several terms were used in this study to describe and maximize the effectiveness of its outcomes. These terms are defined below based upon literature review or their operational value.

Anthropocentric: An attitude or view that believes that humans can control nature.

Attitude: The knowledge, feelings, and behavioral components individuals have as a disposition to act toward some object, person or activity.

Behavior: An action or reaction, or function in some specified way.

Ecocentric: An attitude or view that believes that humans should respect the laws of nature.

Ecologically/Environmentally friendly business: Business or firm that adapts policies and procedures that minimize the impact on the environment.

Eco-trip: A trip that involves travel to natural areas to interact, learn, and experience other cultures, and to economically help local communities that work toward conservation and preservation of the ecosystem. 
Ecotourism: A purposeful travel to natural environment to interact, learn, and experience other cultures, and to economically help local communities that work toward conservation and preservation of the ecosystem.

Ecotoruist: Someone who has taken a purposeful trip to interact with natural environment, to learn and experience other cultures, to economically help local communities that work towards conservation and preservation of ecosystem.

Expectation: To think or believe that it will happen.

Motivation: An internal force and external goals that guide, direct, and integrate a person's behavior for future potential satisfaction.

Service: An act of helpful activity from one person to another.

Tourist: Someone traveling at least 100 miles from home, staying overnight for pleasure or business and not staying more than a year.

Trip: Movement from point $A$ to point $B$ and back. 


\section{SUMMARY}

This chapter introduced the research topic by documenting the growth of ecotourism and identifying the need for a greater understanding of ecotourist's service quality expectations. The problem statement and research objectives were identified to provide the focus for the study. This study will enhance the concept of ecotourism and service quality, and provide a better understanding of the ecotourist market. The findings will be of use to the ecotourist marketers, tour operators and destination promoters to design effective marketing strategies. 


\section{CHAPTER TWO}

\section{REVIEW OF RELATED LITERATURE}

\section{INTRODUCTION}

The primary purpose of this study was to empirically determine the relationship between ecotourist's environmental attitude, environmental behavior, travel motivation, value dimension, travel characteristics and their service quality expectations. Due to the lack of published research in the area of ecotourism, relevant studies from other related fields will be used to substantiate the discussion. This review of literature has been organized into the following topics: Service Quality; Environmental Attitude and Behavior (EAB); Travel Motivation; Value Dimension and Travel Characteristics.

\section{SERVICE QUALITY}

Many service providers are increasingly using higher levels of service quality to position themselves favorably in the marketplace (Parasuraman, Zeithaml, and Berry, 1988; Cronin and Taylor, 1992). Also, it is becoming well established that effective investment in high service quality results in longterm benefits in customer loyalty, and this has proven to be more costeffective, profitable and attracts a bigger market share (Zeithaml et al., 1990). Good service not only enhances a company's ability to attract new customers, but also makes easier to do business with existing customers, and promotes 
cross-selling (Sonnenberg, 1989). This section on service quality is organized under following sub-headings: definition of service quality, and SERVQUAL Instrument and it's application.

\section{Definition of Service Quality}

Though the definition and attributes of service quality are under dispute its contribution to market share; return on investment (Anderson and Zeithaml, 1984); and cost effectiveness are well established. Service quality is an elusive and abstract construct that is hard to define and even harder to measure (Parasuraman, Zeithaml, and Berry, 1985; Carman, 1990; Rathmell 1974). Quality of service is described as the service firm's capacity to meet customers' expectation (Lewis and Booms, 1983;). Cronin and Taylor (1992), defined perceived service quality as an attitude and developed an instrument to measure perceived service quality based on attitude. On the other hand, according to Reeves and Bednar, (1995), among the various definitions proposed in the service literature, two definitions, conformance to specifications and meeting/exceeding expectations have been used most widely. The former is used typically to assess quality of products, and later to assess quality of services.

Service quality has also been described as customer satisfaction by Lewis and Booms (1983), and Parsuraman, Zeithaml, and Berry (1988). According to 
Parasuraman et al. $(1985,1986)$, service quality as perceived by the consumers, is a result of a comparison of expectations of the service they will receive with their perceptions of the service they did actually received. Perceived service quality results from the degree and direction of the discrepancy between customers' expectations or desires and their perceptions. In other words the higher the level of expectations, the lower the perceived service quality; and lower the expectations, the higher the perceived service quality. The degree of discrepancies between the expectations and perceptions is also important, modest or large differences will result in modest or extreme levels of perceived service quality. Since expectations are deemed to vary over time, Carman (1990) cautions that both expectations and performance cannot be measured in the same administration.

According to Parasuraman et al. $(1985,1986)$, service quality expectations of the customers are influenced by several key factors. First, what customers hear from others, word of mouth communications has a potential impact. What one's friends or relatives say has an impact on ones' expectations. Second, all customers have their own personal needs which in turn moderate their expectations to a certain degree. The needs of a young family will be different from needs of an older retired couple. Third, the extent of past service experience could also influence customers' expectation levels. A well traveled ecotourist's expectation will be at a different level from one who is traveling 
for the first time. Fourth, external communications from the service provider also play a key role in shaping the customers' expectations. Colorful brochures of Amazon rain forest imply a promise of adventure and close encounter with natural environment. It is demonstrated that customers' service quality expectations are not isolated but are rather a function of different factors.

Of the many attempts at achieving a better comprehension of service quality, SERVQUAL instrument is perhaps the most noteworthy measurement tool that has made an important contribution in the area of perceived service quality measurement (Day, 1992; Fick and Ritchie, 1991). It has received considerable recognition in the general service marketing literature due to the research work of its developers, Parasuraman, Zeithaml and Berry (1985, 1986, 1988, 1991).

\section{SERVQUAL and its Application}

SERVQUAL is a multiple-item instrument designed to measure customers' expectations and perceptions concerning a service encounter. It consists of five service quality dimensions with 22 items of expectation and perception measures. The numerical difference between the two sets of score for each dimension is considered as the perceived quality score for that dimension. The five dimensions and definitions according to Parasuraman et al. (1988) are: 
Tangibles:

Reliability:

Responsiveness:

Assurance:

Empathy:
Physical facilities, equipment, and appearance of personnel

Ability to perform the promised service dependably and accurately

Willingness to help customers and provide prompt service

Knowledge and courtesy of employees and their ability to convey trust and confidence

Caring, individualized attention the firm provides its customers

SERVQUAL instrument has been widely accepted and applied in numerous studies to measure the perceived service quality since it was developed and tested (Zeithaml, Parasuraman, and Berry, 1990). Results from these studies have shown reliability to be the most important dimension, and tangibles to be the least important. It should be noted that nonhospitality/tourism firms were used in the development of this instrument and it has been proposed as an instrument for measuring perceived service quality within a wide range of service categories. The review of literature shows that very few studies have applied the SERVQUAL instrument in hospitality and tourism research . Relevant published studies are discussed below.

Boulding, Kalra, and Zeithaml (1993), studied the distinction between two types of expectations: first is the prediction of future events or an expectation of what will happen; and second is a normative expectation or an expectation of what will happen. They concluded that perception is a result of 
1) expectations of both what will and what should happen and 2) the reality of the service encounter.

Bojanic and Rosen (1994), examined the nature of the association between service quality as perceived by consumers and its service determinants by applying SERVQUAL in a restaurant setting. They reported, that the general consumer expectations exceeded the actual level of service which resulted in a negative quality scores suggesting that there is always room for improvement. The service dimension that rated highly on expectation was assurance (6.40), followed by reliability (6.27), tangibles (6.17), access (5.81), knowing your customer (5.31), and responsiveness (5.17).

Fick and Ritchie (1991), examined the operation of the SERVQUAL instrument and its management implications in four major sectors of travel and tourism industry namely airline, hotel, restaurant, and ski area service. They found that the two most important expectations concerning service were reliability and assurance for all four sectors of tourism. They also identified several apparent problems with the instrument. Some of the problems or inadequacies identified were 1) problems with positively and negatively worded statements, 2) the inability of the seven-point Likert scale to distinguish subtle differences in expectations and perceptions, 3) its inability to take into account any relationship which might exist between the levels of 
expectations and performance and the cost of that service, and 4) its inadequate attempt to include those tangible factors which contribute to the overall quality of the service expectation. It should be noted that Parasuraman et al. (1991), have since addressed some of the problems in their modified version.

Wicks and Fesenmaier (1993), studied the comparison of visitor and vendor perception of service quality at a special event. They investigated the special event customers' expectations and how vendors or service providers perceived the expectations of the customers, and provided management implications. Dube, Renaghan, and Miller (1994), applied the generic five dimensions to measure the customer satisfaction related to food service. Perdue and Kang (1994) examined the relationship between elements of service quality and consumer satisfaction in a beach tourism settings. Both visitors and resident travelers found trip cost to be the most important satisfaction determinant, and resident travelers also found friendliness of the people, availability of various activities, and the quality of information services as important.

Knutson, Stevens, Wullaert, Patton, and Yokoyama (1990) and Stevens, Knutson, and Patton (1995) applied an adapted version of SERVQUAL instrument in lodging setting (LODGSERV) and restaurant setting (DINESERV) to measure consumers' expectations for service quality. Knutson study 
consisted of 26-items based on five service dimensions as original SERVQUAL scale but the items were worded to capture the consumers expectations of service quality in an hotel experience. Reliability scored highest mean score (mean $=6.63$ ) followed by assurance, responsiveness, tangibles, and empathy (mean=5.84). This study included only the set of items measuring the service quality expectations and set of items for perceptions were excluded.

Stevens et al. (1995), applied the adapted SERVQUAL instrument to the dining experience with statements consisting of what should happen. The instrument consisted of 29 items based on five service dimensions. The findings revealed that reliability (mean $=6.47$ ) once again ranked first followed by tangibles, assurance, responsiveness, and empathy (5.77). Both the lodging and restaurant customers rank reliability as first on the hierarchy, the only difference between the two were the tangibles which ranked second for the restaurant and fourth for the lodging customers.

Though SERVQUAL instrument has received considerable attention and has been widely accepted as a reliable perceived service quality measurement tool, it has been criticized and questioned by Carman (1990). According to Carman (1990), both expectations and performance cannot be measured in the same administration, since expectations are deemed to vary over time. And he further stated that it is hard to conceive that respondents 
can complete an expectations' questionnaire while arriving at the service firm and completing another before departing the service firm.

The above literature review demonstrates that providing service quality is becoming an important factor for businesses to compete in todays' global marketplace, however, inspite of the growth and potential of ecotourism there is little or none published research on the expectations of service quality of ecotourists. Although services such as hotel, restaurant, airlines, and resorts possesses some underlying similarities, significant differences do exist between these entities with respect to ecotourists as opposed to regular tourists. Ecotourists have been distinguished from other tourists, even if visiting the same area, in regard to their travel motivation, education, participation and behavior (Ingram and Durst, 1989; Ziffer, 1989; Fennell and Eagles, 1990;) Ecotourists and mass tourists sought different benefits, according to Crossley and Lee (1994). Since ecotourists were found to be different from mass tourists their service quality expectation deserve a separate inquiry.

Applying the findings of studies done on mass tourists would degrade the explanatory power and potential management recommendations for the ecotourist industry. There is a need to analyze the service quality expectations of the ecotourists so that planners and marketers can take advantage of the 
knowledge and set quality standards as well as maintain a satisfied customer base over a long period of time.

\section{ENVIRONMENTAL ATTITUDE AND BEHAVIOR}

A review of literature revealed several studies related to the environmental attitude and behavior of general public but none dealt with ecotourists. Findings from studies relating to general population or mass tourists are used to substantiate the discussion. This section on environmental attitude and behavior (EAB) is organized as follows: Importance of EAB research, EAB and socio-demographics, EAB and NEP scale.

\section{Importance of EAB Research}

The research on environmental attitude and behavior has received considerable attention in the past decade. Maloney and Ward (1973) characterized the severity of environmental crisis as a "crisis of maladaptive behavior." According to Schahn and Holzer (1990), individual environmental concerns and behavior are equally important factors, and one should not just assume that physical technology or political and economic factors are sufficient. Research has proved that knowledge about the environmental attitude and behavior of the consumers may be a better predictor of future activity preferences (Van Liere and Dunlap, 1980), especially if the general population is showing a trend toward increased environmental consciousness. 
A review of studies pertaining to environmental concerns and attitudes reveal that major emphases is placed on socio-demographic, political ideologies, environmental responsive behavior and recreational behavior relating to the general public (Mohai, 1992; Arcury 1990; Blocker and Eckberg, 1989; Samdahl and Robertson, 1989; Arcury, Johnson, and Scollay, 1986; Mohai and Twight, 1987; Uysal, Noe, and McDonald, 1994).

\section{EAB and Socio-Demographics}

Scott and Willitts (1994) reported that respondents who were younger, better educated, earning higher income and politically liberal were more likely to reject the idea that humans have a right to dominate other life forms. Sociodemographic variables age, education, urban residence, and political ideology were found to have moderate association with environmental attitude (Arcury, 1990). This study further concluded that younger, better educated urban liberal individuals are more concerned and have a positive attitude toward environmental movement. Gender, income, and occupational prestige were found to have weak or inconsistent relationship to environmental issues. In another study by Hines, Hungerford and Tomera, (1987), socio-demographic variables age, gender, and income were found to correlate with environmental concerns. 
Mohai (1992) examining the gender issue reported women to score somewhat higher than men regarding environmental concerns, though they were less environmentally active. Khan and Uysal (1995), found women to be more pro-environmental with regards to both attitude and behavior. Men demonstrated a more anthropocentric (a belief that nature exists primarily for humans to use and has no inherent value of its own) view of nature compared to females. This study also partly confirmed Mohai (1992) findings that women might be more sympathetic toward the environment but on the contrary they were also more proactive in relation to recycling and involvement in environmental activities. In another study female visitors to a national park were found to be pro-environmentalist, showing a stronger opposition to anthropocentric attitudes. However, this study concluded that demographic characteristics seems to play a minor role in identifying environmentally sensitive travelers (Uysal et al. 1994).

Van Liere and Dunlap (1980) reported limited success in proving the role of socio-demographic variables determining environmental concerns, though later Dunlap and Scarce (1991) found the contemporary American society to show widespread environmental concerns. Jackson (1987) found recreationists whose satisfaction depends on relatively unspoiled natural environment (self propelled appreciative activities such as hiking, biking, canoeing, etc.) prefer that natural environment be maintained in its unaltered state compared to 
mechanized recreationists (snow mobiling, motorboating, etc.) who supported development for recreational purposes even at the expense of sacrificing natural environmental quality.

Research relating to environmental behavior has revealed growing concern for environmental problems, the need for increased knowledge, and a general attitude to solve the environmental problems by becoming more involved. Williams (1991) reported that when asked as to whether they had a clear understanding and possessed knowledge about environmental issues, 81 percent responded positively, and 62 percent of the respondents reported to practice recycling regularly. Individuals who actively recycle were found to be both more familiar with recycling programs and more knowledgeable about locally recyclable materials (Vining and Ebreo, 1990).

Environmental attitude and behavior study conducted by Penka (1991), indicated moderate to high levels of environmental concerns and recycling behavior among young respondents. They indicated willingness to take action to reduce environmental harm in their purchases and disposal of waste. A vast majority indicated a desire to learn more about environmental issues, and over 60 percent reported that they practice recycling. 
In a telephone survey conducted by the National Wildlife Foundation (1989) on environmental issues the responses were mostly positive towards environmental protection. Nearly 75 percent of the respondents wanted legislation to mandate recycling of newspaper, glass, and cans in all communities. Ninety four percent agreed that students can have an impact on protecting the environment, but over 80 percent felt that in order to protect the environment the students should have more knowledge about environmental problems and solutions to reduce them. Sixty six percent of the students perceived that industry is more environmentally concerned now than in the past, and 94 percent indicated that they would pay more for environmentally safe packaging and products.

All the above studies were done on general population and there were none dealing with ecotourists' environmental attitude and behavior. In order for the tourism marketers to cater to the growing ecotourist market, a knowledge of their environmental attitude and behavior will be beneficial. Environmental concerns have been measured by various attitude scales, however the New Environmental Paradigm (NEP) scale developed by Dunlap and Van Liere (1978) has received wide attention and has been applied in several studies. 


\section{Environmental Attitude and NEP}

Many studies have used knowledge, beliefs, attitudes, and values as main cognitive variables to explore and analyze environment (Dunlap and Van Liere, 1978; Milbrath, 1984; Van Liere and Dunlap, 1980). Environmental concerns have been measured by various attitude scales developed by Albrecht, Bultena, Moilberg and Nowak, (1982), Dunlap and Van Liere (1978), Maloney and Ward (1973), and Maloney, Ward and Braucht (1975), to name a few. Of the various scales developed to explain the environmental attitude of the consumers, the New Environmental Paradigm (NEP) scale developed by Dunlap and Van Liere (1978) has been used in numerous studies to measure the ecological world view (Dunlap and Van Liere, 1984; Arcury et al. 1986; Arcury, 1990; Scott and Willits, 1994).

According to Dunlap and Van Liere (1978), American society is reflecting a shift in its attitude toward the natural environment, which is challenging the traditional anthropocentric view of nature that it exists primarily to cater to the needs of humans. The new shift reflects aspects of the emerging new environmental paradigm, such as a belief in limits to growth, the necessity of balancing economic growth, the need to preserve the balance of nature, and the need for humans to live in harmony with nature. 
The NEP scale developed by Dunlap and Van Liere (1978), is based on ecocentric views of nature. NEP scale has been used in several studies to compare the orientations of differing sets of interest groups, to compare ethnic groups with Caucasians, and other variables ranging from opposition to local growth to environmental knowledge (Dunlap, Van Liere, Mertig. Catton, and Howell, 1992). However, it was reported that some respondents had problem understanding the specialized terminology of the NEP scale (Noe and Snow, 1990).

In order to address the issues raised in the original scale and to broaden the scale content keeping with the growing salience of "ecological" problems facing the contemporary society, Dunlap et al. (1992) revised the scale and labeled it the "New Ecological Paradigm." Khan and Uysal (1995), applied the new revised New Ecological Paradigm (NEP) to study the environmental attitude and behavior of the university students. The findings revealed proenvironmental attitude groupings to be positively related to proenvironmental behavior groupings, and anti-environmental groupings to be negatively related to pro-environmental behavior groupings.

A vast majority of these studies were conducted on general population except for those done on outdoor recreation, and if ecotourists are looking for natural, more meaningful and educational experience then their environmental 
attitude and behavior patterns deserve a separate inquiry. Also, earlier findings have demonstrated that environmental attitude may be a better predictor of activity preferences compared to demographic characteristics (Uysal et al. 1994). With ecotourism on the rise such a knowledge would be helpful to a tourism marketer in designing marketing strategies for the ecotourists.

\section{TRAVEL MOTIVATION}

A majority of the time recreational travel deals with one fundamental question: "why do people travel?" (Iso-Ahola, 1982). Van Doren (1983), identified that the urge to travel for pleasure depends on individual motivations and cultural conditioning. In order to fully comprehend travel patterns and demand one must examine the travel motivations. Knowledge about travel motivations will help the tourism marketers to design tourism products/services to satisfy the needs and desires of the customers. This section is organized as follow: Definition of Motive, Travel Motivation Theories and Application, and Social Psychological Motivation Theory.

\section{Definition of Motive}

According to Murray (1964), "a motive is an internal force that arouses, directs, and integrates a person's behavior" for future potential satisfaction. Motivation is therefore an interpersonal phenomenon which have led theorists 
to examine pleasure and recreation travel as a psychological experience. It is difficult to examine the travel motivations because of conceptual and methodological issues (Uysal and Hagan, 1993). Different theorists have given different operational definitions to same motivational concepts, namely Lundberg (1971); McIntosh, Goeldner, and Ritchie (1995); Dann (1981); Iso-Ahola (1982); Crompton (1979); Hudman and Hawkins (1989); and Plog (1974). Since Iso-Ahola's motivational theory is used in this study, it will be discussed in more detail compared to other theories.

\section{Travel Motivation Theories and Application}

Lundberg's (1971) study, was probably one of the earliest to address as to why people travel. He identified 18 motivations based on review of literature, ranging from desire to engage in educational and cultural activities to the desire to have a change of weather (for example, getting away from cold weather) and participate in sports (for example, tennis, ski, or swim).

Crompton (1979), conducted 39 unstructured in-depth interviews with a convenience sample on "Motivation for Pleasure Vacation" and identified nine motives. Seven were located toward the socio-psychological end of the disequilibrium continuum and two toward the cultural end. The seven classified motivations are: escape from perceived mundane environment, exploration and evaluation of self, relaxation, prestige, regression, 
enhancement of kinship relationships, and facilitation of social interaction. Novelty and education are the other two on the cultural end. The study suggested that motives are not unidimensional, and one motive is not the reason to travel but rather motives operate in tandem or combination. $\mathrm{He}$ further suggested that tourist industry may pay greater attention to sociopsychological motives in developing product and promotional strategies.

Hudman and Hawkins (1989), identified nine travel motivators: health, curiosity, sports, pleasure, spiritual or religious, professional and business, family and friends, roots syndrome, and esteem. They view people's reasons for travel are wide and diverse, and most trips are motivated by more than one factor since people unconsciously tend to choose vacations that satisfy a combination of needs.

\section{Push and Pull Motivation}

A review of travel motivation literature reveals that travel as a concept of push and pull factors has been widely accepted (Dann, 1977; Crompton, 1979; Pyo, Mihalik and Uysal, 1989; Yuan and McDonald, 1990; Uysal and Hagan, 1993). The push factors for a vacation are regarded as socio-psychological motives and emerges within the traveler. They are origin related motivations and may refer to escape, relax, rest, prestige, adventure, and socio-cultural interactions. Push factors for the ecotourists could be the desire to interact and 
learn about natural environment and other cultures. Maslow's hierarchy of needs has been suggested as a basis for push factors and the six levels related to push factors are: need for self-actualization, self-esteem, recognition/status, belonging, safety/security, and physiological requirements (Uysal and Hagen, 1993). Push factors include "anomie" and "ego-enhancement." The former refers to a situation of perceived normlessness and meaninglessness in the origin society, and the later is usually associated with relative status deprivation in the individual (Dann, 1981).

The pull factors on the other hand are destination related, these motives reflect the influence of the destination in arousing them (Crompton, 1979). Pull factors respond and reinforce the push factors. Pull factors are the attractiveness of a destination whether it be natural or socio-cultural environment. Pyo et al. (1989), demonstrated that destination attractions (pull) can be combined with motivation to travel (push) for a better explanation of travel patterns and behavior.

\section{Social Psychological Motivation Theory}

A social psychological view of travel motivation with regards to tourist behavior was offered by Iso-Ahola (1982) and later by Mannell and Iso-Ahola (1987). They offered a theoretical framework for understanding the driving force behind tourist behavior. Motives are aroused when individuals are 
thinking of certain activities they could, should, or might participate in future that are potentially satisfaction-producing. Satisfaction that individuals are expecting to experience by participating in a leisure activity is linked to two motivational forces. These two motivation forces operate simultaneously to bring about tourist behavior: (1) the desire to leave the everyday environment behind one-self (i.e. escaping personal and/or interpersonal environments), and (2) the desire to obtain psychological (intrinsic) rewards through travel in a contrasting (new or old) environment (i.e. seeking personal and/or interpersonal rewards). In other words individuals perceive any leisure activity (eg. tourism behavior) to provide both the approach (escaping) and avoidance (seeking) components: it provides certain intrinsic rewards such as feelings of mastery and competence, and also helps them to get away from the routine mundane environment.

Tourism because of its characteristics, represents more of a escapeoriented behavior compared to approach-oriented behavior (Iso-Ahola, 1982). If the former is more important than the later, it does not mean that the later is of no consequence, but it can be a threshold factor for the other or it is necessary for achieving the mastery or competence. For instance, for many people visiting India alone may not be enough for them to feel "escape" from the routine unless they can perform certain activities (such as an elephant ride) that provide for the feelings of mastery and achievement. On the other hand if 
approach-oriented behavior is more important for some people, they might still need to escape from their every day environment to experience it. For example, ecotourists to interact and learn about the natural environment and different cultures in Costa Rica, they have to get away from their every day environment. All individual motives can be incorporated in Iso-Ahola's Seeking and Escaping framework that explains the social/psychological tourist motivation (Uysal and Hagan, 1993).

The social psychological theoretical framework of Mannell and IsoAhola (1987) has been applied and confirmed by Ratkai and Smale (1991), and Uysal, Gahan and Martin, (1993). Ratkai and Smale (1991), examined empirically the theoretical framework of tourist motivation to assess the stability of these motives across different groups of individuals. Factor analysis revealed both the escape desire ("get away" and "cultural novelty" ) and seeking desire ("personal" and "social"). The "Get away" dimension contributed the largest proportion of the explained variance. These results reflect empirical validation of the simultaneous operation of two desires (escape and seek) with escape still being the primary travel motive. In addition, the consistent showing of the "Get away" dimension integrating both escape and seeking desires into one dimension with escape being dominant further support Mannell and Iso-Ahola's tourist behavior. 
Uysal et al. (1993), utilized the theoretical framework of tourist motivation proposed by Mannell and Iso-Ahola (1987), to study the event motivation dimensions and to assess the stability and variability of these motives across different groups of individuals with respect to selected events and demographics. Twenty four motivational statements were factor analyzed to delineate the underlying motivational dimensions resulting in five factors labeled as "escape", "excitement/thrills", "event novelty", "socialization", and "family togetherness." "Escape" and "novelty" dimension reflect the escape desire and explained 47 percent of the total variance, and "excitement/thrills" and "socialization" dimension reflect the seek desire as proposed by Mannell and Iso-Ahola. These dimensions were also found to contain items that separate personal and interpersonal rewards. The delineated factor groupings were reasonably stable with respect to different respond categories. This study confirmed and supported the theoretical framework by Mannell and Iso-Ahola and also concurs with the findings of Ratkai and Smale study (1991).

\section{Attraction and Social Motivation of Ecotourists}

Though the tourism literature is replete with studies in the area of travel motivation, limited research has been conducted with regard to what motivates ecotourists. The majority of the studies dealing with the ecotourists are qualitative in nature, either based on observation of behaviors or based on intuition. 
Eagles (1992), studied the travel motivators (attraction and social) of Canadian ecotourists and compared them to mass tourists. Attraction motivations included items relating to important destination features, and social motivations included a set of opinions about personal goals and interaction with others. He used the Canadian Tourism Attitude and Motivational Study (CTAMS) data for mass tourists and the ecotourist data came from three Canadian ecotourist surveys. The three surveys dealt with ecotourists who had participated in trips to Costa Rica, Naturalists' program, and Canadian Nature Tours program respectively during 1985 to 1990 . The findings revealed that ecotourists have clear distinct motivations, and both attraction and social motivations of Canadian ecotourists were found to be substantially different from the average Canadian traveler. They were found to be motivated by wilderness, parks, water, mountain, and rural areas (attraction motivations), and their social motivation that ranked higher were physical activity, meeting people, adventure, and seeing maximum attractions in available time. By contrast, gambling, amusement park, nightlife, big cities, doing nothing, indoor sports, shopping, and resort areas motivations were found to be least descriptive of ecotourists.

The above study confirms Boo's (1990) statement about ecotourists that they are less demanding in terms of lodging, food, and nightlife, and are more willing to accept local conditions, customs and foods. Though the findings 
confirms Boo's statement, the methodology seems to raise questions. The other components of ecotourism besides physical environment and sociability, namely conservation and preservation of ecosystem and economic benefits to the local community were not included.

The above discussion points out that knowledge about travel motivations is important to help explain the travel patterns, however a separate inquiry relating to the travel motivations of the ecotourists is needed if ecotourism marketers and planners are to effectively design product/services to satisfy the needs of the eco-travelers. Since ecotourists were found to be different from mass regular tourists such information will help the providers of eco-services.

\section{VALUE DIMENSION}

Ecotourism is responsible travel to natural areas that conserve the environment and improves the welfare of the local community. According to Lindberg and Huber (1993), ecotourism is seen as a viable tool to promote tourism development along with conservation measures. While defining ecotourism, the benefits (direct or indirect) to the local community have been an important factor: The Ecotourism Society defines ecotourism as a purposeful travel to natural areas that produce economic opportunities to help local conservation efforts. According to Ryel and Grasse (1991), the prefix "eco" refer 
to economics as well as ecology. Economic benefits to the local community that in turn help in the conservation of natural resources and respect the integrity of the ecosystem. Ecotourism while minimizing the negative impact on the environment, should also educate the travelers and the local community about their role in the balance of nature. It is the emphasis on local resources and employment which makes it attractive to the developing countries. Ecotourists as consumers often support the importance of tourism benefitting the local residents (Western, 1993).

In a study conducted by US Travel Data Center (1991), ecotourists rated service and cost as most important factors in selecting travel suppliers. Though environmental responsibility ranked last, it was rated as an important factor by at least 30 percent of the respondents. According to Parasuraman et al. (1991), items about customers' perception of a service cost may be useful to include in the survey questionnaire. But they suggest that such items should be treated separately in analyzing the survey data since they do not fall under the conceptual domain of service quality. While examining the relationship between elements of service quality and consumer satisfaction in beach tourism settings, Perdue and Kang (1994) reported that both visitors and resident travelers found trip cost to be the most important satisfaction determinant. Since cost of services and benefits to the local community were considered important by the ecotourists, this study will group it under "value dimension." 


\section{TRAVEL CHARACTERISTICS}

The most common segmentation technique in use is demographic characteristics of the tourists. The ecotourism company will need to identify the demographic, psychographic and geographic characteristics of the desired group (Ryel and Grasse, 1991). Demographics includes characteristics such as age, education, household income, marital status, occupation, ethnic origin and family size. Though this information is easy to measure and is generally available, it lacks the in-depth analysis. It does not provide the richness needed to explain travel behavior. Psychographis are lifestyles, beliefs and other sociocultural variables. Information about how often ecotourists travel, with whom, where to, travel expenditure, and length of stay will not only give an insight as to what ecotourists do but also help the tourism planners and organizers to better package the tours for this market. Travel characteristics are the most fundamental findings of travel surveys (Chadwick, 1994). Earlier studies have used travel characteristics to determine if it has an impact on travel behavior. 


\section{SUMMARY}

The service literature reinforced the findings that a firm or business to stay competitive should deliver quality service. And in order to deliver service quality the firm or business should understand the service quality expectations of the customers to effectively design product and services. The literature also demonstrated that the SERVQUAL scale can be adapted to measure the service quality expectations of the ecotourists.

While the consumers in general are becoming more environmentally conscious, and ecotourists in particular are seeking natural and educational experience, knowledge about their environmental attitude and behavior patterns may help to understand their future product and service preferences. The revised NEP scale appear to be a reliable instrument to measure the environmental attitude of the ecotourists.

The motivation literature has revealed that knowledge about travel motivations is important to help explain the travel patterns. An inquiry relating to the travel motivations of the ecotourists is needed if ecotourism marketers are to effectively design products/services to satisfy the needs of the travelers. A social psychological framework proposed by Mannell and IsoAholla helps explain the driving force behind why people travel. It supports 
that motivational forces operate simultaneously to bring about tourists behavior, namely escaping and seeking.

An in-depth review of literature revealed that ecotourism as a topic has been scarcely researched. Most of the studies on ecotourism focus on the supply factors namely destination and management practices, with very limited empirical emphasis on the demand factor namely the ecotourist market. Marketers of ecotourism often rely on experience and intuition. Most of the service quality, $\mathrm{EAB}$, and travel motivation studies were done on general population or on mass regular tourists. Since ecotourists are different from mass tourists they deserve a separate inquiry into their service quality expectations, $\mathrm{EAB}$, travel motivation, and value dimension pattern for it might influence their travel patterns and preferences.

From the above review of literature it is evident that to fully and effectively satisfy ecotourists, the tourism marketer need to be aware of the service quality expectations of the ecotourists. The strategy of tailoring the product/service to specific consumer expectations has a potential for improving both market share and profitability. It was also demonstrated that customers' service expectations are influenced by various factors. Since ecotourists were found to be different from mass tourists, have different travel motivations, seek interaction in the natural environment, look for more 
educational experiences, it can be concluded that their service quality expectation is a function of these factors. An attempt was made in this study to empirically determine the relationship between ecotourist's environmental attitude, environmental behavior, travel motivation, value dimension, travel characteristics and their service quality expectations. A conceptual model is proposed to test such a relationship. Such knowledge will help the ecotourist service providers to effectively package products/services to best satisfy the needs of the ecotourists and to maintain a satisfied and long term customer base.

This chapter has focused on the review of literature in service quality, environmental attitude and behavior, travel motivations, value dimension and travel characteristics. The next chapter will discusses the methodology used for this study. 


\section{CHAPTER THREE}

\section{METHODOLOGY}

\section{INTRODUCTION}

The preceding chapters defined the research domain of this study as a relationship between environmental attitude; environmental behavior; travel motivation and value dimension; and service quality expectation of ecotourists. This chapter will present the research framework, proposed conceptual model; state the hypotheses which will be used to guide this empirical study; outline the research design and the instrument that will be used to collect and quantify the data; and finally discuss the analyses of data.

\section{RESEARCH FRAMEWORK}

The main objective of this study was to empirically determine the relationship between ecotourists' environmental attitude, environmental behavior, travel motivation, value dimension, and their service quality expectations. Therefore this study includes five sets of research constructs: service quality expectation, environmental attitude, environmental behavior, travel motivation, and value dimension.

Service quality expectation was the dependent variable in this study. Service expectation refers to the service level that customers believe they 
"should get" from the service provider. It is the service firm's capacity to meet customers expectations. The service attributes the customers might use as criteria in assesing service performance are the five dimensions that formed the basis of measuring service quality in the SERVQUAL scale developed by Parasuraman, Zeithmal, and Berry (1986, 1988 and 1991). The five dimensions were tangibility, reliability, responsiveness, assurance and empathy.

The independent variables in this study were the environmental attitude, environmental behavior, travel motivation and value dimension. Travel characteristics was also treated as an independent variable. The variables are described as follows.

Environmental attitude relates to ecotourists' views, feelings, and beliefs regarding the heightened interest in global environmental change. It reflects the American society's shift in its attitude toward the natural environment, which challenges the traditional anthropocentric view that nature exists primarily to cater to the needs of humans. It includes a belief in limits to growth, ecocentrism, fragile balance of nature, rejection of exemptionalism, and ecological catastrophe.

Environmental behavior focuses on the habits and practices of the ecotourists in relation to environmental issues. The past two decades have 
demonstrated that the environmental movement has entered the mainstream of global lifestyle. Consumers, in general, are increasingly adapting behavior patterns that spell environmental consciousness. Several studies have reported that practice of recycling, involvement in environmental issues, ecologically conscious buying habits and environmental concerns are gaining importance (Khan and Uysal, 1995; Penka, 1991; Vining and Ebreo, 1990).

Travel motivation basically deals with the question as to why people travel and what motives them to travel or partcipate in leisure activity. Satisfaction that individuals are expecting to experience by participating in a leisure activity is linked to two motivational forces which operate simultaneously to bring about tourist behavior: (1) the desire to leave the everyday environment behind one-self (i.e. escaping personal and/or interpersonal environment), and (2) the desire to obtain psychological (intrinsic) rewards through travel in a contrasting (new or old) environment (i.e. seeking personal and/or interpersonal rewards). Mannell and Iso-Ahola (1987), offered a theoretical framework for understanding the driving force behind tourist behavior.

The value dimension relates to price or cost of services and the economical and social benefits of tourism to the local community. Cost of services is indicative of a willingness on the part of the customer to purchase a 
product or service, while the benefits indicate a willingness on the part of the service provider to use part of its profits to help the local community. Earlier findings have reported that ecotourists are willing to pay more to those businesses that are environmentally friendly and help in community programs. Therefore the cost and benefit issues important to the ecotourists were included in the value dimension.

Demographic and travel characteristics of the tourists help in better understanding the behavior of the travelers.

The relationship between the variables discussed above are presented in a proposed model, which is derived from literature review of service quality expectation and ecotourism.

\section{ECOSERV: A Proposed Conceptual Model}

The proposed conceptual ECOSERV model (Figure 1) looks at the relationship between the independent variables (environmental attitude, behavior, travel motivation, value dimension and travel characteristics) and the dependent variable (service quality expectation). This relationship between the two sets of variables is exploratory in nature and does not assume any causal relationships. 


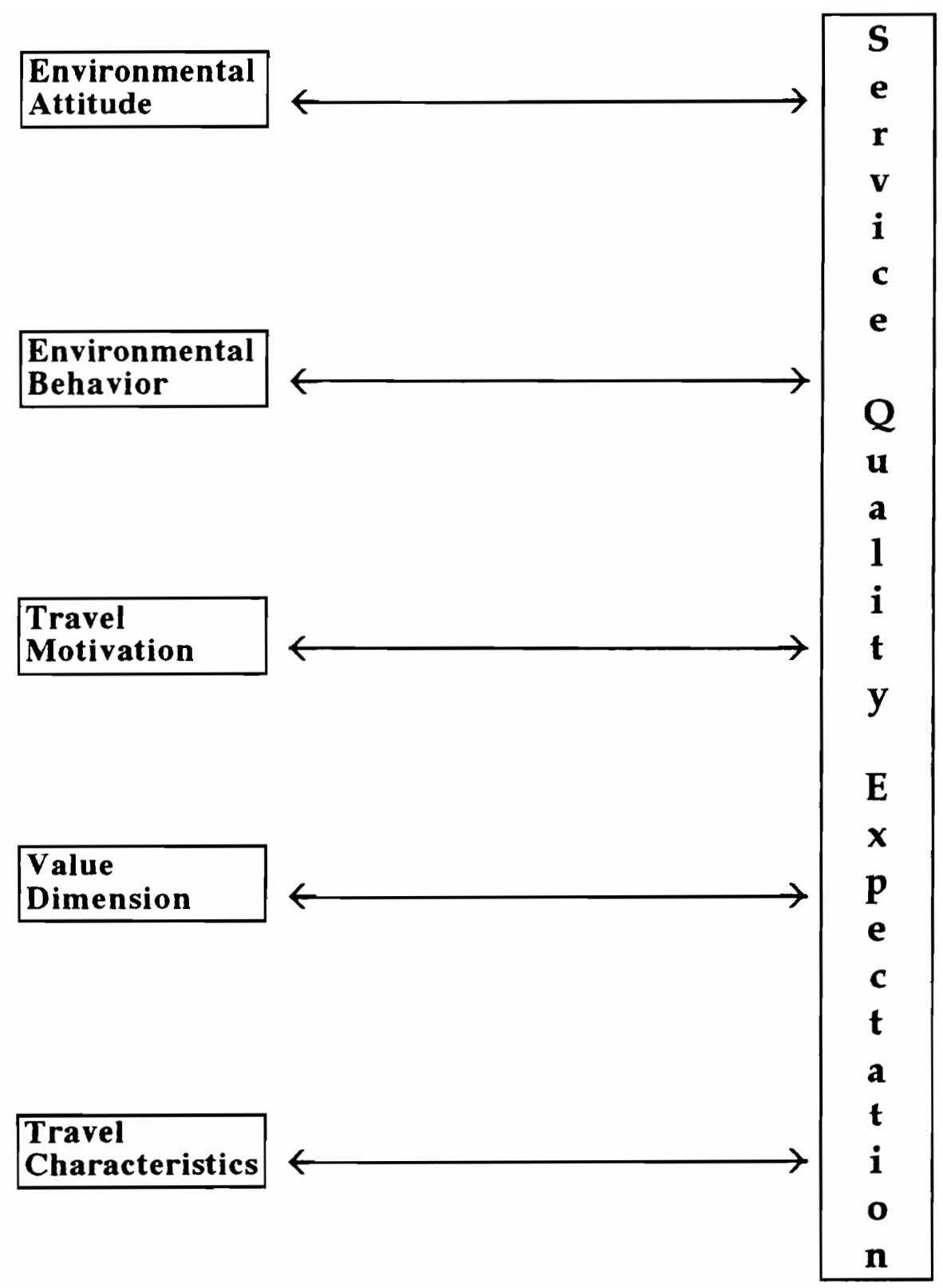

Figure 1 ECOSERV:

Proposed Conceptual Model for Service Quality Expectations 
The literature review demonstrates that providing service quality is becoming an important factor for businesses to compete in the global marketplace. A knowledge of ecotourists' service quality expectation can help an ecotourist business to effectively cater to this growing market segment. According to Parasuraman et al. (1988), several key factors might shape customers' expectations. All customers have their own personal needs which in turn moderate their expectations to a certain degree. Individual characteristics and circumstances moderate customers' expectations. For example, a customers' attitude and behavior toward the environment might be related to service expectations about an ecotourist business. If a customer's beliefs regarding the environment is oriented toward ecocentric (man has no right to rule over nature), then his/her service expectations might differ from a customer whose beliefs are more anthropocentric (man has a right to rule over nature). Also, if a customer is concerned about the environment and strongly believes that there is a limit to growth on this earth, then that customers' service quality expectation might be environmentally friendly.

The extent of past experience in using a service could also be related to customers' expectation levels. A nature enthusiast, for instance, might demand services that are more ecologically friendly. A person who is pro-environment or practices environmentally friendly habits might expect businesses to minimize the negative impact on environment. External communications from 
service providers play a key role in shaping customers' expectations. External communications, direct or indirect messages conveyed by an ecotourist business regarding natural experience or indigenous culture implies a promise of a certain service. If an ecotourist is traveling for educational purposes, such as seeking knowledge about the environment or cultural interaction, then that ecotourist might expect services to be informative about the environment and indigenous culture. Price or cost of services part of external communications play an important role in shaping customers' expectations. Although cost of service may be included in the survey questionnaire, it does not fall under the domain of service quality and as such should be treated separately (Parasuraman et al. 1991).

The travel motivation of escaping and seeking might be related to the service quality expectation of an ecotourist. The socio-psychological factors that are unique to each tourist, such as the urge to get away from daily routine or a need to seek self-gratification, might influence service quality expectations. Ecotourists were found to be motivated by natural and educational experience whereas least descriptive motivations were doing nothing, gambling, amusement park, nightlife, shopping and visiting big cities (Eagles, 1992). Since ecotourists are seeking educational and natural experiences their service quality expectation might be related to their motivations to travel. 
Ecotourists' willingness to pay more for services and businesses that are environmentally friendly might influence their service expectations. Since ecotourist businesses are expected to economically benefit the local community and help in conservation efforts, in this study the independent variable 'value' includes both the cost of services and benefits to the local community.

As the literature review from previous studies suggest, ecotourists are travelers who are interested in nature-oriented, educational, and active/participatory experiences. They are environmentally friendly travelers who emphasize seeing and saving natural habitat and archeological treasures. They are interested in learning first-hand about the ecosystem, endangered species, and complex issues such as deforestation. They visit natural areas to observe and study the natural features. They prefer experiencing natural environment within a contest of wilderness and undisturbed areas. They prefer facilities that are environmentally friendly and minimize the use of natural resources. They are more willing to accept and appreciate local conditions, customs, and foods. Though cost and service were rated as important by the ecotourists, they are willing to pay more for travel services and products provided by environmentally responsible suppliers (Ceballos-Lascurain, 1994; Eagles, 1992; Ryel and Grasse, 1991; Kutay, 1991; Whelan, 1991; and Boo, 1990; Ingram and Durst, 1989). 
Based on the characteristics of the ecotourists some factors that might influence the service quality expectations of the ecotourists can be their attitude towards environment, their behavior towards environmental concerns, their motivation to seek natural experience and their emphasis on value dimension. Therefore, an attempt was made in this study to propose a conceptual model ECOSERV - that can determine the relationship between environmental attitude; environmental behavior; travel motivation and value dimension; and service quality expectations of the ecotourists.

\section{RESEARCH HYPOTHESES}

A proposed conceptual model of ecotourists' service quality expectation was developed to evaluate and test the primary research hypotheses which state:

H1: There is no significant relationship between environmental attitude and service quality expectations of the ecotourists.

H2: There is no significant relationship between environmental behavior and service quality expectations of the ecotourists.

H3: There is no significant relationship between travel motivations and service quality expectations of the ecotourists. 
H4: There is no significant relationship between value dimension and service quality expectations of the ecotourists.

H5: There is no significant relationship between environmental attitude; environmental behavior; travel motivation and value dimension collectively; and service quality expectations of the ecotourists.

H6: There is no significant difference between travel characteristics and service quality expectations of the ecotourists.

\section{DESIGN OF THE STUDY}

This research focused on a relatively unexplored area of tourism phenomenon and was conducted using survey methodology. The relevant unit of analysis for this study was the ecotourist. The design of this study was correlational and the hypotheses were advanced to test possible relationships between the independent and dependent variables in the proposed conceptual model.

In order to measure environmental behavior, travel motivation, value dimension and service quality expectations of the ecotouirsts, various scales were developed based on relevent literature review. A nominal group 
technique approach followed by three-step pilot study was used to check the wording, layout and comprehension of the items used in the survey.

\section{Nominal Group Technique}

A nominal group technique is a systematic approach, and one of its output is to provide a list of ideas relevent to a topic in question. A nominal group was held during an ecotourism workshop in St. John, US Virgin Islands during summer of 1995 to generate relevent ideas relating to service expectations of the ecotourits. The group consisted of nine participants who were attending the ecotourism workshop. Appendix (1) includes a listing of service features expected from ecotourist service providers to meet customers' expectations. Information provided by the group was included in environmental behavior, travel motivation, value dimension and service quality expectation measurement scales.

\section{SCALES AND DEVELOPMENT}

Different scales were used to measure environmental attitude, environmental behavior, travel motivations and service quality expectations of the ecotourists. The scales developed and used in the study are as follows: 


\section{Environmental Attitude (NEP) Scale}

The environmental attitude of the ecotourist was measured by utilizing the revised New Ecological Paradigm (NEP) scale developed by Dunlap et al. (1992). The revised scale was used instead of the original scale, which was also developed by Dunlap and Van Liere (1978). The new and revised scale offered an improved coverage of key ecological aspects, has slightly more internal consistency, and has three more items than the original scale. Also, the original scale was coming under a great deal of criticism as to its relevance to the changing views relating to environmental issues.

The revised NEP scale was used in a mail survey of a representative sample of Washington State residents (Dunlap et al., 1992). Principle component analysis was performed to assess the internal consistency of the measures. Varimax rotation resulted in four factors, however it was reported that there was a substantial degree of cross-loading present, as seven of the 15 items load at least .3 on two factors. It was concluded that the revised set of 15 items can legitimately be treated as a "New Ecological Paradigm Scale," since a good deal of internal consistency was evident. Future research on differing samples was recommended to confirm the appropriateness of treating the new set of 15 items as a single measure of endorsement of an ecological worldview. 
The present study utilized all 15 items of the NEP scale which explains the ecological worldview namely: the reality of limits to growth, antianthropocentrism, the fragility of nature's balance, and the possibility of ecological catastrophe (Table 1). Attitude construct was measured on a five point Likert-type scale ranging from 1 "strongly agree" to 5 "strongly disagree."

\section{Environmental Behavior Scale}

The environmental behavior scale used in this study to measure the behavioral pattern of the ecotourists was adapted from the original set of behavior items developed by Khan and Uysal (1995). They initially used 15 behavior items which resulted in three factor groups explaining $55.5 \%$ of total variance. The reliability coefficients for these delineated factor groups were: (1) Practice of recycling (.79), (2) Involvement in environmental issues (.78), and (3) Buying habits (.76).

The present study utilized the original 15 behavior items. Five more behavior items were included based on the ecotourism literature and information provided by the nominal group technique. Table 2 shows the environmental behavior items and corresponding factors used in this study. The 20 behavior items were measured on a Likert-type scale ranging from 1 "always" to 4 "never." 
Factors and Items

\section{Limits to Growth}

1. We are approaching the limit of the number of people the earth can support

2. The earth has plenty of natural resources if we just learn how to develop them

3. The earth is like a space ship with very limited room and resources

\section{Anti-anthropocentrism}

4. Humans have the right to modify the natural environment to suit their needs

5. Plants and animals have as much right as humans to exists

6. Humans were meant to rule over rest of nature

\section{Balance of Nature is Fragile}

7. When humans interfere with nature it often produces disastrous consequences

8. The balance of nature is strong enough to cope with the impacts of modern industrial nations

9. The balance of nature is very delicate and easily upset

\section{Rejection of Exemptionalism}

10. Human ingenuity will insure that we do NOT make the earth unlivable

11. Despite our special abilities humans are still subject to the laws of nature

12. Humans will eventually learn enough about how nature works to be able to control it

\section{Ecological Catastrophe}

13. Humans are severely abusing the environment

14. The so-called "ecological crisis" facing humankind has been greatly exaggerated

15. If things continue on their present course, we will experience a mojor ecological catastrophe

*Source: Dunlap, Van Liere, Mertig, Catton, and Howell, 1992 


\section{TABLE 2 ENVIRONMENTAL BEHAVIOR SCALE}

\begin{tabular}{|c|c|c|}
\hline & Factors and Items & $* a, b$ \\
\hline 1. & $\begin{array}{l}\text { Practice of Recycling } \\
\text { Do you practice recycling of cans }\end{array}$ & \\
\hline 2. & Do you practice recycling of paper & \\
\hline 3. & Do you practice recycling of glass & \\
\hline 4. & Do you practice recycling of plastic & \\
\hline 5. & Do you practice recycling of oil & \\
\hline 6. & $\begin{array}{l}\text { Involvement in Environmental Issues } \\
\text { Do you consider participation in environmental related protests }\end{array}$ & \\
\hline 7. & Do you consider giving money to environmental organizations & \\
\hline 8. & Do you consider doing volunteer work for environmental groups & \\
\hline 9. & $\begin{array}{l}\text { Do you consider writing letters to officials regarding } \\
\text { environmental issues }\end{array}$ & \\
\hline 10. & $\begin{array}{l}\text { Environmentally Friendly Buying Habits } \\
\text { Do you consider being more environmentally friendly if you were } \\
\text { the one incharge of policies and procedures }\end{array}$ & $\mathbf{a}$ \\
\hline 11. & $\begin{array}{l}\text { Do you avoid purchasing products from companies that pollute } \\
\text { environment }\end{array}$ & \\
\hline 12. & $\begin{array}{l}\text { Do you avoid purchasing of certain foods because of the chemicals } \\
\text { used }\end{array}$ & \\
\hline 13. & Do you buy reduced packaging products & \\
\hline 14. & Do you buy products made of recycled materials whenever possible & \\
\hline 15. & Do you avoid using aerosol spray cans & \\
\hline 16. & $\begin{array}{l}\text { Concerns for the Environment } \\
\text { Do you have concerns for the environment }\end{array}$ & a \\
\hline 17. & $\begin{array}{l}\text { Do you patronize businesses that have environmentally friendly } \\
\text { practices }\end{array}$ & $\mathbf{b}$ \\
\hline 18. & $\begin{array}{l}\text { Do you think businesses are more environmentally friendly than } \\
\text { ten years back }\end{array}$ & $\mathbf{a}$ \\
\hline 19. & Do you want to know more about the environment & $\mathbf{b}$ \\
\hline 20. & $\begin{array}{l}\text { Do you think environmental issues should be given number one } \\
\text { priority }\end{array}$ & $\mathbf{a}$ \\
\hline
\end{tabular}

\footnotetext{
* Note: a Ecotourism literature (Whelan 1991, and Boo 1990)

b Nominal Group Technique
} 


\section{TABLE 3 TRAVEL MOTIVATION SCALE}

\begin{tabular}{|l|l|c|c|c|c|}
\hline & Items & $\mathbf{a}^{*}$ & $\mathbf{b}^{*}$ & $\mathbf{c}^{*}$ & $\mathbf{d}^{*}$ \\
\hline 1. & To get away from the demands of life & $\mathrm{x}$ & $\mathrm{x}$ & $\mathrm{x}$ & \\
\hline 2. & To relax and do nothing & $\mathrm{x}$ & & $\mathrm{x}$ & \\
\hline 3. & To get away from crowds & & & & \\
\hline 4. & To have a change from the routine & & $\mathrm{x}$ & & \\
\hline 5. & For a change of pace from every day life & & $\mathrm{x}$ & & \\
\hline 6. & To get away from commercial tourists spots & & & & \\
\hline 7. & To enjoy purposeful travel & & & $\mathrm{x}$ & \\
\hline 8. & To try new foods & $\mathrm{x}$ & & $\mathrm{x}$ & \\
\hline 9. & Because I am curious & & $\mathrm{x}$ & & \\
\hline 10. & To rediscover myself & $\mathrm{x}$ & & $\mathrm{x}$ & \\
\hline 11. & To be daring and adventuresome & $\mathrm{x}$ & & $\mathrm{x}$ & \\
\hline 12. & To participate in outdoor activities & & & $\mathrm{x}$ & $\mathrm{x}$ \\
\hline 13. & To know more about the environment & & & $\mathrm{x}$ & $\mathrm{x}$ \\
\hline 14. & To learn about the flora / the fauna & & & $\mathrm{x}$ & $\mathrm{x}$ \\
\hline 15. & To learn more about nature & & & $\mathrm{x}$ & $\mathrm{x}$ \\
\hline 16. & To learn about other cultures & & & $\mathrm{x}$ & $\mathrm{x}$ \\
\hline 17. & To learn about local lifestyles & & & $\mathrm{x}$ & $\mathrm{x}$ \\
\hline 18. & To experience unpolluted natural settings & & & $\mathrm{x}$ & $\mathrm{x}$ \\
\hline 19. & To visit historical and cultural sites & & & & \\
\hline & /monuments & $\mathrm{x}$ & & $\mathrm{x}$ & \\
\hline 20. & To be with my family & $\mathrm{x}$ & & $\mathrm{x}$ & \\
\hline 21. & To be with my friends & & & & \\
\hline 22. & To meet people from different cultures & & & $\mathrm{x}$ & \\
\hline 23. & To learn host country language & & & $\mathrm{x}$ & \\
\hline 24. & To be with people of similar interests & $\mathrm{x}$ & $\mathrm{x}$ & $\mathrm{x}$ & \\
\hline 25. & Ilike to participate in local entertainment & $\mathrm{x}$ & & & $\mathrm{x}$ \\
\hline 26. & To be by myself & & & & \\
\hline & & & & \\
\hline
\end{tabular}

* Sources:

a Ratkai and Smale, 1991

b Uysal, Gahan, and Martin, 1993

c Ecotourism literature (Eagles, 1992, Whelan 1991, and Boo 1990)

d Nominal Group Technique 
Table 4 VALUE DIMENSION SCALE

\begin{tabular}{|l|c|}
\hline Value items & ${ }^{*} \mathrm{a}, \mathrm{b}$ \\
\hline $\begin{array}{l}\text { Ecotourist services costs more than regular tourist } \\
\text { services }\end{array}$ & $\mathrm{x}$ \\
\hline $\begin{array}{l}\text { Customers do not expect to pay more than regular } \\
\text { tourism services }\end{array}$ & $\mathrm{x}$ \\
\hline $\begin{array}{l}\text { Use part of the profits to educate the } \\
\text { customers/locals about environmental issues }\end{array}$ & $\mathrm{x}$ \\
\hline $\begin{array}{l}\text { Provide environmentally friendly services at a } \\
\text { reasonable cost }\end{array}$ & $\mathrm{x}$ \\
\hline $\begin{array}{l}\text { Use part of the profits to benefit community } \\
\text { projects }\end{array}$ & $\mathrm{x}$ \\
\hline
\end{tabular}

* Note: a Ecotourism literature (Boo 1990, Ryel and Grasse 1991, and Western, 1993)

b Nominal Group Technique 


\section{Travel Motivation Scale}

The travel motivation scale utilized the theoretical framework of leisure motivation based on escape and seek dimensions as proposed by Mannell and Iso-Ahola (1987). Ratkai and Smale (1991) applied factor analysis to empirically validate the theoretical framework of travel motivation, by revealing underlying dimensions quite consistent with the escaping and seeking desires. Uysal et al., (1993) studied the travel motivations of the event and festival goers and further validated the findings of escape and seek desires. Three dimensions (excitement/thrills, socialization, and family togetherness) reflected the seeking desires and two dimensions (escape and event novelty) reflected the escaping desires.

Table 3 presents the 26 items used in this study to measure travel motivations of the ecotourists, that reflects both escaping and seeking dimensions of travel motivation. The items selected are based on earlier travel motivation studies (Ratkai and Smale, 1991; Eagles, 1992; Uysal, Gahan, and Martin, 1993), ecotourism literature, and information provided by the nominal group technique. These items were measured on a five point Likert-type scale ranging from 1 "very important" to 5 "not-at-all important." 


\section{Value Scale}

The five items used to measure the value dimension are presented in Table 4. It includes items pertaining to service costs and the benefits to the community by an ecotourist business. A seven point Likert-type scale was used to measure these items. The items were selected on the basis of ecotourism literature and nominal group technique suggestions.

Earlier findings have reported that ecotourists were willing to pay more to those businesses that are environmentally friendly. One way the businesses can show they are environmentally friendly is by using part of their profits to educate the host/guests about environmental issues and also by investing in conservation efforts locally. The nominal technique group also emphasized that there should be some sort of an accountability on the part of the ecotourist service providers. Since ecotourists were willing to pay more to businesses that are environmentally friendly and they prefer businesses to help in community projects, these items were included in the value dimension scale.

\section{ECOSERV an adapted version of SERVQUAL}

The service quality expectation of the ecotourists was measured by an adapted version of SERVQUAL scale, which was developed by Parasuraman et al. $(1986,1988$, and 1991). The adapted version was labelled as ECOSERV. 
SERVQUAL is a multiple-item instrument designed to measure customers' expectations and perceptions concerning a service encounter. It is a part of a longitudinal study that involves series of interviews with consumer focus groups, consumer surveys, and scale refinement procedures. Initially 97 items representing 10 determinants of service namely, tangibles, reliability, responsiveness, competence, courtesy, credibility, security, access, communication, and understanding the customer were included. Due to overlapping found between dimensions during analysis, the original 10 dimensions were combined into five new dimensions. Therefore, the final SERVQUAL instrument consists of 22 items of expectations and perceptions each based on five service quality dimensions. The scores for each statement were recorded on a seven-point Likert type scale from one to seven, one being "strongly disagree" and seven being "strongly agree." The five dimensions and definitions according to Parasuraman et al. (1988) are:

Tangibles: Physical facilities, equipment, and appearance of personnel

Reliability: Ability to perform the promised service dependably and accurately

Responsiveness: Willingness to help customers and provide prompt service

Assurance: $\quad$ Knowledge and courtesy of employees and their ability to convey trust and confidence

Empathy: Caring, individualized attention the firm provides its customers 
SERVQUAL instrument is a useful measurement tool that has made an important and valuable contribution in the area of perceived service quality measurement (Day, 1992; Fick and Ritchie, 1991). But it has also raised questions about the validity and reliability of the original scale, the authors since then have addressed these concerns or presented counter arguments. According Parasuraman et al. (1991), it is a generic instrument with good reliability and validity and broad applicability. Though it has received considerable recognition in the general service marketing literature, its application in the area of hospitality and tourism has been very limited. Knutson et al. (1990) and Stevens et al. (1995) applied an adapted version of SERVQUAL instrument in lodging setting (LODGSERV) and restaurant setting (DINESERV), to measure consumers' expectations for service quality.

The present study used an adapted version of SERVQUAL scale to measure the service quality expectations of the ecotourists. Table 5 gives a comparison of SERVQUAL items with the items used in this study for ECOSERV (proposed). The items were measured on a seven point Likert-type scale, ranging from 1 "strongly disagree" to 7 "strongly agree."

Environmental issues and information provided by the ecotourist business were the two most important features of services desired by the participants of the nominal group technique. Most of the services relating to 
TABLE 5 SERVICE QUALITY EXPECTATION SCALES: A Comparison

\begin{tabular}{|c|c|c|c|}
\hline & SERVQUAL SCALE & ECOSERV SCALE (proposed) & * \\
\hline 1. & $\begin{array}{l}\text { Tangibles } \\
\text { Excellent companies will have } \\
\text { modern -looking equipment }\end{array}$ & $\begin{array}{l}\text { Tangibles } \\
\text { Excellent ecotourist businesses will } \\
\text { have equipment that minimizes } \\
\text { environmental degradation }\end{array}$ & $x x$ \\
\hline 2. & & $\begin{array}{l}\text { The facilities at excellent ecotourist } \\
\text { businesses will be appropriate to the } \\
\text { environment }\end{array}$ & $\mathbf{a}$ \\
\hline 3. & & $\begin{array}{l}\text { The facilities at excellent ecotourist } \\
\text { businesses will be environmentally } \\
\text { safe }\end{array}$ & a \\
\hline 4. & $\begin{array}{l}\text { The physical facilities at } \\
\text { excellent companies will be } \\
\text { visually appealing }\end{array}$ & $\begin{array}{l}\text { The physical facilities at excellent } \\
\text { ecotourist businesses will be visually } \\
\text { appealing }\end{array}$ & s \\
\hline 5. & & $\begin{array}{l}\text { The facilities at excellent ecotourist } \\
\text { businesses will be located in an } \\
\text { unpolluted environment. }\end{array}$ & $\mathbf{a}$ \\
\hline 6. & & $\begin{array}{l}\text { The physical facilities at excellent } \\
\text { ecotourist businesses will reflect } \\
\text { local influence }\end{array}$ & a \\
\hline 7. & & $\begin{array}{l}\text { The facilities at excellent ecotourist } \\
\text { businesses will provide local } \\
\text { entertainment }\end{array}$ & a \\
\hline 8. & $\begin{array}{l}\text { Employees at excellent } \\
\text { companies will be neat- } \\
\text { appearing }\end{array}$ & $\begin{array}{l}\text { Employees at ecotourist businesses } \\
\text { will be neat-appearing in local attire }\end{array}$ & $x x$ \\
\hline 9. & & $\begin{array}{l}\text { Employees of excellent ecotourist } \\
\text { businesses will be neat-looking in } \\
\text { comfortable attire. }\end{array}$ & a \\
\hline 10. & $\begin{array}{l}\text { Materials associated with the } \\
\text { service (such as pamphlets or } \\
\text { statements) will be visually } \\
\text { appealing in an excellent } \\
\text { companies }\end{array}$ & $\begin{array}{l}\text { Materials associated with the service } \\
\text { (such as pamphlets or statements) } \\
\text { will be visually appealing with local } \\
\text { taste in an excellent ecotourist } \\
\text { business }\end{array}$ & $x x$ \\
\hline 11. & & $\begin{array}{l}\text { Materials associated with the service } \\
\text { (such as pamphlets or statements) } \\
\text { will reflect local influence in } \\
\text { excellent ecotourist businesses }\end{array}$ & $\mathbf{a}$ \\
\hline
\end{tabular}

* Note: $x x$ - adapted; a - added; $s$ - original SERVQUAL items. 
TABLE 5 SERVICE QUALITY EXPECTATION SCALES: A Comparison

\begin{tabular}{|c|c|c|c|}
\hline & SERVQUAL Scale & ECOSERV Scale (proposed) & * \\
\hline 12. & $\begin{array}{l}\text { Reliability } \\
\text { When excellent companies } \\
\text { promise to do something by } \\
\text { certain time, they will do so }\end{array}$ & $\begin{array}{l}\text { Reliability } \\
\text { When ecotourists businesses } \\
\text { promise to do something by certain } \\
\text { time, they will do so }\end{array}$ & s \\
\hline 13. & $\begin{array}{l}\text { When a customer has a } \\
\text { problem, excellent companies } \\
\text { will show a sincere interest in } \\
\text { solving it }\end{array}$ & $\begin{array}{l}\text { When a customer has a problem, } \\
\text { excellent ecotourist business will } \\
\text { show a sincere interest in solving it }\end{array}$ & $\mathbf{s}$ \\
\hline 14. & $\begin{array}{l}\text { Excellent companies will } \\
\text { perform the service right the } \\
\text { first time }\end{array}$ & $\begin{array}{l}\text { Excellent ecotourist businesses will } \\
\text { perform the service right the first } \\
\text { time }\end{array}$ & $s$ \\
\hline 15. & $\begin{array}{l}\text { Excellent companies will } \\
\text { provide their services at the } \\
\text { time they promise to do so }\end{array}$ & $\begin{array}{l}\text { Excellent ecotourist businesses will } \\
\text { provide their services at the time } \\
\text { they promise to do so }\end{array}$ & $\mathbf{s}$ \\
\hline 16. & $\begin{array}{l}\text { Excellent companies will insist } \\
\text { on error-free records }\end{array}$ & $\begin{array}{l}\text { Excellent ecotourist businesses will } \\
\text { insist on error-free records }\end{array}$ & $\mathbf{s}$ \\
\hline 17. & $\begin{array}{l}\text { Responsiveness } \\
\text { Employees in excellent } \\
\text { companies will tell customers } \\
\text { exactly when services will be } \\
\text { performed }\end{array}$ & $\begin{array}{l}\text { Responsiveness } \\
\text { Employees in excellent ecotourist } \\
\text { businesses will tell customers } \\
\text { exactly when services will be } \\
\text { performed }\end{array}$ & $s$ \\
\hline 18. & $\begin{array}{l}\text { Employees in excellent } \\
\text { companies will give prompt } \\
\text { service to the customers }\end{array}$ & $\begin{array}{l}\text { Employees in excellent ecotourist } \\
\text { businesses will give prompt service } \\
\text { to the customers }\end{array}$ & s \\
\hline 19. & $\begin{array}{l}\text { Employees in excellent } \\
\text { companies will always be } \\
\text { willing to help customers }\end{array}$ & $\begin{array}{l}\text { Employees in excellent ecotourist } \\
\text { businesses will always be willing to } \\
\text { help customers }\end{array}$ & $\mathbf{s}$ \\
\hline 20. & $\begin{array}{l}\text { Employees in excellent } \\
\text { companies will never be too } \\
\text { busy to respond to customers' } \\
\text { requests }\end{array}$ & $\begin{array}{l}\text { Employees in excellent companies } \\
\text { will never be too busy to respond to } \\
\text { customers' requests }\end{array}$ & $\mathbf{s}$ \\
\hline
\end{tabular}

* Note: $x x$ - adapted; a - added; $s$ - original SERVQUAL items. 
TABLE 5 SERVICE QUALITY EXPECTATION SCALES: A comparison

\begin{tabular}{|c|c|c|c|}
\hline & SERVQUAL Scale & ECOSERV Scale (proposed) & * \\
\hline 21. & $\begin{array}{l}\text { Assurance } \\
\text { Behavior of employees in } \\
\text { excellent companies will instill } \\
\text { confidence in customers }\end{array}$ & $\begin{array}{l}\text { Assurance } \\
\text { Behavior of employees in excellent } \\
\text { ecotourist businesses will instill } \\
\text { confidence in customers }\end{array}$ & $\mathbf{s}$ \\
\hline 22. & $\begin{array}{l}\text { Customers of excelent } \\
\text { companies will feel safe in } \\
\text { their transactions }\end{array}$ & $\begin{array}{l}\text { Customers of excellent ecotourist } \\
\text { businesses will feel safe in their } \\
\text { transactions }\end{array}$ & s \\
\hline 23. & $\begin{array}{l}\text { Employees in excellent } \\
\text { companies will be consistently } \\
\text { courteous with customers }\end{array}$ & $\begin{array}{l}\text { Employees in excellent ecotourist } \\
\text { businesses will be consistently } \\
\text { courteous with customers }\end{array}$ & $s$ \\
\hline 24. & $\begin{array}{l}\text { Employees in excellent } \\
\text { companies will have the } \\
\text { knowledge to answer } \\
\text { customers' questions }\end{array}$ & $\begin{array}{l}\text { Employees in excellent ecotourist } \\
\text { businesses will have the knowledge } \\
\text { to answer customers' questions }\end{array}$ & $s$ \\
\hline 25. & $\begin{array}{l}\text { Empathy } \\
\text { Excellent companies will give } \\
\text { customers individual attention. }\end{array}$ & $\begin{array}{l}\text { Empathy } \\
\text { Excellent ecotourist businesses will } \\
\text { give customers individual attention. }\end{array}$ & s \\
\hline 26. & $\begin{array}{l}\text { Excellent companies will have } \\
\text { operating hours convenient to } \\
\text { all their customers }\end{array}$ & $\begin{array}{l}\text { Excellent ecotourists businesses will } \\
\text { have operating hours convenient to } \\
\text { all their customers }\end{array}$ & s \\
\hline 27. & $\begin{array}{l}\text { Excellent companies will have } \\
\text { employees who give customers } \\
\text { personal attention }\end{array}$ & $\begin{array}{l}\text { Excellent ecotourists businesses will } \\
\text { have employees who give } \\
\text { customers personal attention }\end{array}$ & s \\
\hline 28. & $\begin{array}{l}\text { Excellent companies will have } \\
\text { customer's best interest at heart }\end{array}$ & $\begin{array}{l}\text { Excellent ecotouristbusinesses will } \\
\text { have customer's best interest at } \\
\text { heart }\end{array}$ & s \\
\hline 29. & $\begin{array}{l}\text { Employees of excellent } \\
\text { companies will understand the } \\
\text { specific needs of their } \\
\text { customers }\end{array}$ & $\begin{array}{l}\text { Employees of excellent ecotourist } \\
\text { businesses will understand the } \\
\text { specific needs of their customers }\end{array}$ & $s$ \\
\hline 30. & & $\begin{array}{l}\text { Excellent ecotourists businesses will } \\
\text { provide necessary information to } \\
\text { customers }\end{array}$ & a \\
\hline
\end{tabular}

* Note: $x x$ - adapted; a - added; $s$ - original SERVQUAL items. 
environmental issues were added on to the tangibles service dimension. The SERVQUAL scale used four items to measure the tangible dimension of service, whereas the proposed ECOSERV scale had eleven items emphasizing the environmental and cultural issues. These items were either adapted or added based on the information provided by the nominal group technique and ecotourism literature. According to the Ecotourism Society (1992), ecotourism is "a purposeful travel to natural areas to understand the culture and natural history of the environment, taking care not to alter the integrity of the ecosystem, while producing economic opportunities that make the conservation of the natural resources beneficial to localpeople."

Information about trips, trails, weather, interpretive channels, and events was regarded as an important part of service by the nominal group technique. Therefore an item named "provide necessary information" was added to the list. A closer examination of the comparison between SERVQUAL and proposed ECOSERV items reveals that most of the items that were used in measuring the four service dimensions (reliability, responsiveness, assurance and empathy), were mostly identical except for the use of "excellent ecotourist business" instead of " excellent companies."

One of the guidelines in ensuring the most appropriate and effective use of SERVQUAL is to use it in its entirety as much as possible. While minor 
modifications in wording of the items to adapt them to a specific setting are appropriate, deletion of items could affect the integrity of the scale and cast doubt on whether the reduced scale fully captures service quality (Parasuraman et al. 1991). ECOSERV scale used 19 of the original 22 items mentioned in the SERVQUAL scale, adapted 3, and added 8 items, for a total of 30 items to measure the service quality expectations of the ecotourists. The ECOSERV scale was sent to one of the developers (Parasuraman) of the original SERVQUAL scale for evaluation of its wording, layout, and comprehension before it was used in the pilot study for further validation.

\section{Pilot Study}

A pilot study was conducted in three steps to test and revise the environmental behavior, travel motivation, value dimension and service quality expectation scales. First, a draft of ECOSERV (adapted SERVQUAL) scale and travel motivation scale, was administered to twenty selected faculty and graduate students (Appendix 2). The scales were revised based on their recommendation and feedback.

Next, the whole questionnaire was circulated to twenty selected faculty and graduate students at Virginia Polytechnic Institute and State University for feedback regarding wording, layout, and comprehension of the items. Again based on their feedback and recommendations the questionnaire was revised. 
Lastly, the revised questionnaire was mailed to fifty ecotourists, whose names were provided by the tour operators. This was done to pretest the questionnaire as well as to see if the names provided by the tour operators were usable. Out of fifty, 17 responses were received. The adapted ECOSERV and travel motivation dimensions were tested for reliability. The responses were found to be satisfactory and the revised survey instrument was considered ready to be administered to the final sample.

\section{Survey Instrument}

Scales developed (as mentioned above) were complied into a selfreported survey questionnaire. The final survey instrument consisted of the following major sections (Appendix 3).

1. Section One was designed to measure the travel characteristics of the ecotourists. Items included were based on earlier studies, for example, travel group, accommodation preference, number of nights stayed, travel expenditure, and trip planning.

2. Section Two included 15 items of environmental attitude (NEP).

3. Section Three included 20 environmental behavior items.

4. Section Four included 26 travel motivation items.

5. Section Five included 30 items of service quality expectation (ECOSERV). 
6. Section Six was designed to measure the demographic characteristics of the ecotourists, for example, age, gender, income, marital status, education, community, occupation and ethnic background.

\section{Population and Sample}

The population for this study consisted of ecotourists. Sample for this study came from the mailing list of ecotourists provided by the tour operators who specialize in ecotourism. Fifty one tour operators in North America were contacted to provide the mailing list of ecotourists who have utilized their services and have taken a trip in the past year. First, request letters were mailed in November of 1995 to the tour operators followed by fax or phone calls when necessary. A total of 1400 names and addresses were received from seven tour operators to create a sampling frame. In an earlier study conducted by Crossley and Lee (1994) to assess the differences in benefits sought by ecotourists compared to mass tourists, the list of participants was obtained from two tour companies, one specializing in ecotours and the other offering traditional tours.

Sample selection is a very important part of a research, so steps were taken to generate a sample that represented the ecotourist market. The tour operators selected were not only members of the Ecotourism Society (a reputed international agency based in the USA that is fully devoted to ecotourism), but 
were also representatives of the ecotourist industry. These tour operators offer variety of destinations covering geographically diverse areas from Alaska to South America, Asia and Africa. An ecotourist sample of 1200 was drawn at random from the names provided by the seven tour operators. The sample size selected was based on budgetary restrictions. Names with incomplete or duplicate addresses were omitted, which resulted in a final sample size of 1051 . The primary method of data collection was the mail survey questionnaire. A self-administered questionnaire was distributed to 1051 ecotourists who have used the services of the tour operators specializing in eco-trips to natural areas that provide opportunities for interacting, learning, and educating oneself about nature and its environment.

\section{Research Procedures}

A cover letter (Appendix 4) on the letterhead of the Department of Hospitality and Tourism Management at Virginia Tech was used. It included information about the purpose of the study, requested voluntary participation, and assured confidentiality of their responses. The questionnaires were mailed on May 29, 1996. A follow-up letter was used to increase the response rate as suggested by Dillman (1978). Three weeks later a follow-up letter was mailed to half of the original sample. Since the responses were steadily arriving, the remaining follow-up letters were not sent. A response rate of 30-35 percent was considered sufficient to analyze the data. 
As an incentive to increase the response rate, a lottery drawing was promised to all respondents who returned a coupon included in the survey. Two prizes were offered, one included a seven night stay for two at a highly popular ecotourist destination in St. John's, the US Virgin Islands, and the second prize was a day trip in the island of Hawaii. Both prizes were sponsored by respective corporations.

\section{NON-RESPONSE BIAS}

Possible non-response biases were addressed by comparing the responses of the early respondents to those of the late respondents. This is one method by which such biases can be addressed. According to Armstrong and Overton (1977), such comparisons are often similar and are commonly used for testing the non-response bias. Early responses $(n=35)$ were received on June 9 and June 10, 1996. Late responses were received between August 10 and August 30, 1996. Chi-square and t-tests were performed between the two groups on selected variables to reveal if there was any significant difference. The findings are discussed in the following chapter.

\section{VALIDITY AND RELIABILITY TESTS}

Validity refers to the degree to which the instrument is measuring what it purports to measure. Reliability on the other hand refers to the degree to which observations are consistent and stable (Rosenthal and Rosnow, 1984). 
The NEP, environmental behavior, and SERVQUAL scales have all been previously applied and tested, and their reliability coefficients are well established. However, in the context of this study (except NEP scale) other scales were adapted based on ecotourism literature and recommendations of the focus group. In order to detect any possible variations, reliability coefficients were calculated. The reliability results are discussed in the following chapter.

The face or content validity of the instrument was checked by conducting a three-step pilot study. As mentioned earlier the face validity of the proposed ECOSERV scale was further checked by having Parasuraman (one of the developer of SERVQUAL scale) evaluate it for its layout, wording and comprehensibility. Factor analysis and inter-item correlation measures were also conducted to further check the reliability.

\section{ANALYSES OF DATA}

All data were coded and analyzed using the Statistical Package for Social Sciences (SPSS) version 4.0. Pearson's correlation coefficient analysis was used to test hypothesis 1 to hypothesis 4 , and the canonical correlation analysis to test hypothesis 5 using SAS statistical package (release 6.07). The analysis of the study consisted of three steps: (1) Descriptive statistics that included frequency descriptions and measures of central tendency; (2) Data reduction analysis: 
factor analysis; and (3) Inferential statistics that included analysis of variance, t-test, Duncan's multiple range test, Pearson's correlation coefficient and canonical correlation analysis. Statistical analyses in order they where applied are listed as follows:

1. Initial analyses included the calculation of frequencies on all variables. Descriptive statistics: mean, median, and standard deviation, were performed.

2. The 15 NEP items were factor analyzed to delineate and confirm the underlying dimensions of environmental attitudes relating to the ecotourists.

3. The 20 environmental behavior items were factor analyzed to delineate and confirm the underlying dimensions of environmental behavior patterns relating to the ecotourists.

4. The 26 travel motivation items were factor analyzed to delineate and confirm the underlying dimensions of travel motivation patterns relating to the ecotourists.

5. The $\mathbf{5}$ value dimension items were factor analyzed to delineate and confirm the underlying dimensions of value patterns relating to the ecotourists. 
6. The 30 ECOSERV items were factor analyzed to delineate and confirm the underlying dimensions of service quality expectations relating to the ecotourists.

7. Cronbach alpha correlation coefficient, a measure of internal consistency, was conducted for the reliability of (a) ECOSERV (proposed) - service quality expectation dimension measures;

b) NEP - environmental attitude dimension measures;

c) environmental behavior dimension measures; d) travel motivation dimension measures and e) value dimension measures.

Testing of Research Hypotheses:

8. H1: There is no significant relationship between environmental attitude and service quality expectations of the ecotourists. Pearson correlation coefficient was performed to quantify the strength of the linear relationship between environmental attitude and ECOSERV. 
9. H2: There is no significant relationship between environmental behavior and service quality expectations of the ecotourists.

Pearson correlation coefficient was performed to quantify the strength of the linear relationship between environmental behavior and ECOSERV.

10. H3: There is no significant relationship between travel motivations and service quality expectations of the ecotourists.

Pearson correlation coefficient was performed to quantify the strength of the linear relationship between travel motivations and ECOSERV.

11. H4: There is no significant relationship between value dimension characteristics and service quality expectations of the ecotourists.

Pearson correlation coefficient was performed to quantify the strength of the linear relationship between value dimension and ECOSERV. 
12. H5: There is no significant relationship between environmental attitude, environmental behavior, travel motivation and value dimension collectively, and seroice quality expectations of the ecotourists.

Canonical correlation analysis was used to investigate the relationship between two sets of variables: environmental attitude, environmental behavior, travel motivation and value dimension collectively, and ECOSERV.

13. H6: There is no significant relationship between travel characteristics and service quality expectations of the ecotourists.

Delineated ECOSERV factors were compared across selected travel characteristics. One-way analyses of variance and t-tests were used to examine variation among ECOSERV factors. 


\section{SUMMARY}

In this chapter the the research framework, proposed conceptual model and specific research hypotheses were stated. Further, the research design, population, sample, scale and development, validity and reliability tests, and method of data analyses were discussed. The results are presented in the following chapter. 


\section{CHAPTER FOUR}

\section{RESULTS AND DISCUSSION}

\section{INTRODUCTION}

Chapter three elaborated on the research methods that were used to investigate the research question. It included research design, development of the survey instrument and statistical procedures selected to examine the relationship between the research constructs: environmental attitude, environmental behavior, travel motivation, value dimension and service quality expectation as the dependent variable. The preceding chapter also described the research hypotheses that were derived from the theoretical propositions.

This chapter will include discussion and interpretation of the data collected, validity and reliability tests, a profile of the respondents, and hypotheses testing. Through the utilization of select statistical techniques, this chapter presents the results of the proposed research questions.

\section{DATA COLLECTED}

The sample population in this study was composed of ecotourists who have taken an eco-trip in the past eighteen months. A total of 1051 questionnaires were mailed on May 29 1996, out of which 39 questionnaire 
were returned due to change of address or incomplete address. The final sample consisted of 1012 ecotourists.

Summary of the response rate is presented in Table 6. By August 30, 1996, a total of 331 surveys were returned for an approximate response of 32.7 percent. Of those received 7 surveys were not usable because of excessive missing data. After eliminating the unusable responses, 324 responses were coded for data analyses. This resulted in a response rate of 32 percent.

\section{PROFILE OF RESPONDENTS}

\section{Demographic Characteristics of Ecotourists}

The demographic data collected from section six of the survey questionnaire are presented in Table 7 . The majority of the respondents were from $45-54$ year old group (32.2\%), followed by $35-44$ year old group (23.5\%), 55-64 year old group (21.1\%), 65-74 year old group (9.9\%), 25-34 year old group (6.8\%), over 75 year old group (2.5\%), 20-24 year old group (22\%) and under 20

year old group (1.9\%). Respondents between 35 to 64 years old comprised $76.8 \%$ of the total population. The respondents were $43.7 \%$ male and $55.4 \%$ female. Approximately $55.7 \%$ of the respondents attended graduate school, $38.1 \%$ attended four year college and $6.1 \%$ attended high school. 
Table 6 OVERALL RESPONSE RATE

\begin{tabular}{|l|r|c|}
\hline & $\begin{array}{c}\text { Number } \\
(\mathrm{N})\end{array}$ & $\begin{array}{c}\text { Percent } \\
\%\end{array}$ \\
\hline $\begin{array}{l}\text { Total target population } \\
\text { (mailed on May 29, 1996) } \\
\text { Less non-delivered }\end{array}$ & 1,051 & 100 \\
\hline Total population & 39 & 3.7 \\
Total responses & 1012 & 100 \\
Less usable & 331 & 32.7 \\
\hline $\begin{array}{l}\text { Total usable responses } \\
\text { (recieved by August 30, 1996) }\end{array}$ & 324 & 32.00 \\
\hline
\end{tabular}




\begin{tabular}{|c|c|c|}
\hline Variables & $\begin{array}{c}\text { Frequency } \\
(\mathrm{N}=324)\end{array}$ & $\begin{array}{c}\text { Percent } \\
(\%)\end{array}$ \\
\hline \multicolumn{3}{|l|}{ Age (vears) } \\
\hline Under 20 & 6 & 1.9 \\
\hline $20-24$ & 7 & 2.2 \\
\hline $25-34$ & 22 & 6.8 \\
\hline $35-44$ & 76 & 23.5 \\
\hline $45-54$ & 104 & 32.2 \\
\hline $55-64$ & 68 & 21.1 \\
\hline $65-74$ & 32 & 9.9 \\
\hline Over 75 & 8 & 2.5 \\
\hline \multicolumn{3}{|l|}{ Gender } \\
\hline$\overline{\text { Male }}$ & 141 & 43.7 \\
\hline Female & 179 & 55.4 \\
\hline \multicolumn{3}{|l|}{ Education } \\
\hline High school & 20 & 6.1 \\
\hline Four year college & 123 & 38.1 \\
\hline Graduate school & 180 & 55.7 \\
\hline \multicolumn{3}{|l|}{ Marital Status } \\
\hline Never Married & 71 & 22.0 \\
\hline Married & 175 & 54.2 \\
\hline Divorced/Separated & 47 & 14.6 \\
\hline Widowed & 21 & 6.5 \\
\hline \multicolumn{3}{|l|}{ Household } \\
\hline Single living alone & 95 & 29.4 \\
\hline Married couple $w / o$ children & 67 & 20.7 \\
\hline Married couple w children & 43 & 13.3 \\
\hline Middle-aged couple w all children elsewhere & 36 & 11.1 \\
\hline Single with children & 12 & 3.7 \\
\hline Retired couple (at least one spouse retired) & 34 & 10.5 \\
\hline \multicolumn{3}{|l|}{ Community } \\
\hline Rural & 43 & 13.3 \\
\hline Small town & 62 & 19.2 \\
\hline City & 91 & 28.2 \\
\hline Suburban & 108 & 33.4 \\
\hline Other & 4 & 1.2 \\
\hline
\end{tabular}


Table 7 DEMOGRAPHIC PROFILE OF ECOTOURISTS (Contd.)

\begin{tabular}{|c|c|c|}
\hline Variables & $\begin{array}{r}\text { Frequency } \\
\qquad(\mathbf{N}=324)\end{array}$ & $\begin{array}{c}\text { Percent } \\
(\%)\end{array}$ \\
\hline \multicolumn{3}{|l|}{ Household Income } \\
\hline Under $\$ 19,000$ & 4 & 1.2 \\
\hline$\$ 20,000-\$ 29,000$ & 21 & 6.5 \\
\hline$\$ 30,000-\$ 39,000$ & 16 & 5.0 \\
\hline$\$ 40,000-\$ 49,000$ & 23 & 7.1 \\
\hline$\$ 50,000-\$ 59,000$ & 36 & 11.1 \\
\hline$\$ 60,000-\$ 69,000$ & 30 & 9.3 \\
\hline$\$ 70,000-\$ 79,000$ & 30 & 9.3 \\
\hline$\$ 80,000-\$ 89,000$ & 22 & 6.8 \\
\hline$\$ 90,000-\$ 99,000$ & 17 & 5.3 \\
\hline Over $\$ 100,000$ & 79 & 24.5 \\
\hline \multicolumn{3}{|l|}{ Occupation } \\
\hline Homemaker & 14 & 4.3 \\
\hline Professional-Technical & 111 & 34.4 \\
\hline Executive-Administration & 19 & 5.9 \\
\hline Middles management & 14 & 4.3 \\
\hline Sales-Marketing & 15 & 4.6 \\
\hline Clerical & 5 & 1.5 \\
\hline Laborer-Worker & 4 & 1.2 \\
\hline Student & 7 & 2.2 \\
\hline Self-employed & 33 & 10.2 \\
\hline Teacher & 18 & 5.6 \\
\hline Retired & 57 & 17.6 \\
\hline Other & 5 & 1.5 \\
\hline \multicolumn{3}{|l|}{ Spouse Occupation } \\
\hline Homemaker & 13 & 4.0 \\
\hline Professional-Technical & 55 & 17.0 \\
\hline Executive-Administration & 19 & 5.9 \\
\hline Middles management & 8 & 2.5 \\
\hline Sales-Marketing & 9 & 2.8 \\
\hline Clerical & 7 & 2.2 \\
\hline Laborer-Worker & 1 & 0.3 \\
\hline Student & 2 & 0.6 \\
\hline Self-employed & 17 & 5.3 \\
\hline Teacher & 5 & 1.5 \\
\hline Retired & 44 & 13.6 \\
\hline Other & 5 & 1.5 \\
\hline
\end{tabular}


Table 7 DEMOGRAPHIC PROFILE OF ECOTOURISTS (Contd.)

\begin{tabular}{lrr}
\hline Variables & $\begin{array}{c}\text { Frequency } \\
(\mathbf{N = 3 2 4 )}\end{array}$ & $\begin{array}{c}\text { Percent } \\
(\%)\end{array}$ \\
\hline Race & & \\
African American & 9 & 2.8 \\
White & 284 & 87.9 \\
Asian & 6 & 1.9 \\
Native American & 2 & 0.6 \\
Other & 10 & 3.1 \\
\hline
\end{tabular}


Majority of the respondents were married $(54.2 \%)$, followed by never married group (22.0\%), divorced/separated group (14.6\%) and widowed group (6.5\%). Majority of the households comprised of married couples $(55 \%)$, out of which $20.7 \%$ were married couple without children, $13.3 \%$ were married couple with children group, $11.1 \%$ were middle-aged couple with children living elsewhere group, and retired couple with at least one spouse retired group (10.5\%). Other groups were single living alone group (29.4\%) and single with children group (3.7\%). Income levels revealed that $24.5 \%$ had an income of over $\$ 100,000$ and only $1.2 \%$ had income under $\$ 19,000$. Approximately $66.3 \%$ had income between $\$ 50,000$ to over $\$ 100,000$.

Respondents living in suburban areas comprised of $33.4 \%$, followed by city dwellers (28.2\%), small town (19.2\%) and rural household(13.3\%). Majority of the respondents were employed as professional/technical (34.4\%), followed by retired group (17.6\%). Also approximately $10.2 \%$ were self-employed. As far as race was concerned a large majority identified themselves as White (87.9\%), followed by African American (2.8\%), Asian (1.9\%), and Native American $(0.6 \%)$. The other group comprised of $3.1 \%$, among which majority identified themselves as Hispanic.

Table 8 shows the geographical distribution of residence (state). A total of $17 \%$ of the respondents lived in California, followed by New York $(9.0 \%)$, 
Table 8 GEOGRAPHIC DISTRIBUTION OF RESPONDENTS

\begin{tabular}{lrc}
\hline State & Frequency & Percent \\
\hline Alabama & 2 & 0.6 \\
Alaska & 2 & 0.6 \\
Arizona & 6 & 1.9 \\
California & 55 & 17.0 \\
Colorado & 8 & 2.5 \\
Connecticut & 10 & 3.1 \\
Florida & 23 & 7.1 \\
Georgia & 2 & 0.6 \\
Hawaii & 3 & 0.9 \\
Ilinois & 14 & 4.3 \\
Indiana & 5 & 1.5 \\
Iowa & 2 & 0.6 \\
Maine & 5 & 1.5 \\
Maryland & 8 & 2.5 \\
Massachusetts & 12 & 3.7 \\
Michigan & 17 & 5.3 \\
Minnesota & 3 & 0.9 \\
Mississippi & 1 & 0.3 \\
Missouri & 1 & 0.3 \\
Nevada & 1 & 0.3 \\
New Hampshire & 1 & 0.3 \\
New Jersey & 1 & 4.0 \\
New Mexico & 13 & 0.3 \\
New York & 1 & 9.0 \\
North Carolina & 29 & 3.1 \\
North Dakota & 10 & 0.3 \\
Ohio & 1 & 4.0 \\
Oklahoma & 13 & 0.3 \\
Oregon & 1 & 2.2 \\
Pennsylvania & 7 & 4.0 \\
Rhode Island & 13 & 0.6 \\
South Carolina & 2 & 0.9 \\
South Dakota & 3 & 0.6 \\
Tennessee & 2 & 0.3 \\
Texas & 1 & 1.9 \\
Utah & 6 & 0.3 \\
Vermont & 1 & 1.5 \\
Virginia & 1 & 2.5 \\
Washington & 5 & 0.6 \\
West Virginia & 8 & 0.3 \\
Wisconsin & 2 & \\
\hline & & \\
\hline & 1.2 \\
\hline
\end{tabular}


Florida (7.1\%) and Michigan (5.3\%). Illinois, Pennsylvania and New Jersey each had $4.0 \%$ of the respondents.

\section{Travel Characteristics of Ecotourists}

Travel characteristics of the ecotourists are presented in Table 9. The findings revealed that majority of the ecotourists took overseas trips (59\%) compared to $41 \%$ whose trips were not overseas. Majority of the ecotourists traveled with organized groups $(33.7 \%)$ or with family $(32.5 \%)$, followed by friends $(18.6 \%)$, alone $(9.9 \%)$ or other $(4 \%)$. Number of nights stayed on the trip was an open ended question and average nights spent were 13 nights. It revealed four groups, ecotourists who stayed one week $(20.4 \%)$, two weeks $(52.6 \%)$, three weeks $(18.0 \%)$ and over three weeks $(8.0 \%)$. More than $50 \%$ of the respondents stayed two weeks.

Responses for lodging type information showed that majority stayed at hotel/motel (29.7\%), followed by cabins $(26.3 \%)$ and tents $(13.8 \%)$. Approximately $40 \%$ of the respondents stayed in cabins and tents. Majority of the respondents used air travel (75.5\%) as a primary mode of transportation to arrive at the destination, and only $2.2 \%$ used cruise ship. Total expenditure for the trip was solicited by an open ended question. It revealed three groups, ecotourists who spend under $\$ 2000(29.4 \%)$, between $\$ 2100$ to $\$ 5000$ (51.8\%) and over $\$ 5000(18.8 \%)$. The mean total expenditure was $\$ 3714$. Majority of the 


\begin{tabular}{|c|c|c|}
\hline & $\begin{array}{c}\text { Frequency } \\
(\mathrm{N}=324)\end{array}$ & $\begin{array}{c}\text { Percent } \\
(\%)\end{array}$ \\
\hline \multicolumn{3}{|l|}{ Overseas Trip } \\
\hline Yes & 185 & 58.9 \\
\hline No & 129 & 41.1 \\
\hline \multicolumn{3}{|l|}{ Travel Group } \\
\hline Alone & 32 & 9.9 \\
\hline Friends & 60 & 18.6 \\
\hline Family & 105 & 32.5 \\
\hline Organized group & 109 & 33.7 \\
\hline Other & 13 & 4.0 \\
\hline \multicolumn{3}{|l|}{ Number of Nights } \\
\hline one week & 66 & 20.4 \\
\hline two weeks & 170 & 52.6 \\
\hline 3 weeks & 58 & 18.0 \\
\hline 3 weeks \& more & 26 & 8.0 \\
\hline \multicolumn{3}{|l|}{ Lodging Type } \\
\hline Hotel-Motel & 96 & 29.7 \\
\hline Bed/Breakfast & 9 & 2.8 \\
\hline Huts & 8 & 2.5 \\
\hline Friends/Relatives & 7 & 2.2 \\
\hline Campgrounds & 9 & 28 \\
\hline Tents & 45 & 13.8 \\
\hline Cabins & 85 & 26.3 \\
\hline Ranch & 6 & 1.9 \\
\hline Other & 57 & 17.6 \\
\hline \multicolumn{3}{|l|}{ Mode of } \\
\hline \multicolumn{3}{|l|}{ Transportation } \\
\hline Personal auto & 15 & 4.6 \\
\hline Rental auto & 10 & 3.1 \\
\hline Air travel & 244 & 75.5 \\
\hline Tour Bus & 18 & 5.6 \\
\hline Cruise ship & 7 & 2.2 \\
\hline Other & 19 & 5.9 \\
\hline
\end{tabular}


Table 9 TRAVEL CHARACTERISTICS (contd.)

\begin{tabular}{lrc}
\hline & $\begin{array}{c}\text { Frequency } \\
(\mathrm{N}=324)\end{array}$ & $\begin{array}{c}\text { Percent } \\
(\%)\end{array}$ \\
\hline Total Expenditure & & \\
\hline under $\$ 2000$ & 92 & 29.4 \\
$\$ 2100-\$ 5000$ & 162 & 51.8 \\
\$5000 and above & 59 & 18.8 \\
& & \\
Trip Planning & 2 & .6 \\
\hline Less than 2 weeks & 11 & 3.4 \\
3-4 weeks & 76 & 13.0 \\
1-3 months & 42 & 20.4 \\
3-4 months & 66 & 36.8 \\
$5-6$ months & 119 & \\
More than 6 months & & \\
\hline
\end{tabular}


respondents took more than six months $(36.8 \%)$ to plan the trip followed by one to three months $(23.5 \%)$ and five to six months $(20.4 \%)$. Only 0.6 percent took less than two weeks to plan the trip.

\section{Environmental Attitude of Ecotourists}

Table 10 shows the environmental attitude of the ecotourists. NEP scale used to measure the attitude consisted of 15 items explaining the ecological worldview namely: the reality of limits to growth, anti-anthropocentrism, the fragility of nature's balance, and the possibility of ecological catastrophe. Agreement with eight of the 15 statements is interpreted as agreement with the ecological worldview, while disagreement with the other seven statements reflects anti-anthropocentric view. Eight statements with mean scores of 1.91 , $2.16,1.69,1.72,1.76,1.40,1.68$, and 2.16 were interpreted as agreement with ecological worldview, whereas seven statements with mean scores $\left(^{*}\right)$ of 3.11 , $3.80,3.95,4.21,3.71,3.74$ and 4.01 were interpreted as anti-anthropocentric worldview (Table 10). This rejection of anthropocentrism showed that ecotourists are challenging the traditional anthropocentric view of nature that it exists primarily to cater to the needs of humans.

\section{Environmental Behavior of Ecotourists}

Statistics of environmental behavior characteristics relating to the practice of recycling, concerns for the environment, involvement in 
Table 10 DESCRIPTIVE ANALYSIS OF ENVIRONMENTAL ATTITUDE

\begin{tabular}{|c|c|c|c|}
\hline Environmental Attitude Items & Mean & SD & $\begin{array}{l}\text { No. of } \\
\text { resp. }\end{array}$ \\
\hline $\begin{array}{l}\text { We are approaching the limit of the number of } \\
\text { people the earth can support } \\
\text { The earth has plenty of natural resources if we just }\end{array}$ & 1.91 & 1.02 & 311 \\
\hline learn how to develop them & $3.11^{*}$ & 1.34 & 310 \\
\hline $\begin{array}{l}\text { The earth is like a space ship with very limited } \\
\text { room and resources }\end{array}$ & 2.16 & 1.2 & 310 \\
\hline $\begin{array}{l}\text { Humans have the right to modify the natural } \\
\text { environment to suit their needs }\end{array}$ & $3.80^{*}$ & 1.10 & 306 \\
\hline $\begin{array}{l}\text { Plants and animals have as much right as humans } \\
\text { to exists }\end{array}$ & 1.69 & 1.04 & 302 \\
\hline Humans were meant to rule over rest of nature & $3.95^{*}$ & 1.21 & 304 \\
\hline $\begin{array}{l}\text { When humans interfere with nature it often } \\
\text { produces disastrous consequences }\end{array}$ & 1.72 & 1.00 & 311 \\
\hline $\begin{array}{l}\text { The balance of nature is strong enough to cope with } \\
\text { the impacts of modern industrial nations }\end{array}$ & $4.21^{*}$ & .96 & 308 \\
\hline $\begin{array}{l}\text { The balance of nature is very delicate and easily } \\
\text { upset }\end{array}$ & 1.76 & 1.06 & 302 \\
\hline $\begin{array}{l}\text { Human ingenuity will insure that we do NOT make } \\
\text { the earth unlivable }\end{array}$ & $3.71^{*}$ & 1.15 & 307 \\
\hline $\begin{array}{l}\text { Despite our special abilities humans are still } \\
\text { subject to the laws of nature }\end{array}$ & 1.40 & .72 & 304 \\
\hline $\begin{array}{l}\text { Humans will eventually learn enough about how } \\
\text { nature works to be able to control it } \\
\text { Humans are severely abusing the environment }\end{array}$ & $3.74^{*}$ & 1.11 & 306 \\
\hline & 1.68 & 1.04 & 303 \\
\hline $\begin{array}{l}\text { The so-called "ecological crisis" facing humankind } \\
\text { has been greatly exaggerated } \\
\text { If things continue on their present course, we will }\end{array}$ & $4.01 *$ & 1.14 & 305 \\
\hline experience a major ecological catastrophe & 2.16 & 1.15 & 304 \\
\hline
\end{tabular}

Likert-type scale was used to measure each item: 1 = strongly agree;

2 = somewhat agree; $3=$ neutral; $4=$ somewhat disagree; and $5=$ strongly disagree. 


\begin{tabular}{|c|c|c|c|}
\hline Environmental Behavior Items & Mean & SD & $\begin{array}{l}\text { No. of } \\
\text { resp. }\end{array}$ \\
\hline \multicolumn{4}{|l|}{ Practice recycling of cans } \\
\hline & 1.21 & .51 & 300 \\
\hline Practice recycling of paper & & & \\
\hline Practice recycling of glass & 1.20 & .57 & 300 \\
\hline & 1.33 & .72 & 297 \\
\hline Practice recycling of plastic & 1.41 & .75 & 295 \\
\hline Practice recycling of oil & 1.77 & 1.08 & 273 \\
\hline $\begin{array}{l}\text { Consider participation in environmental related } \\
\text { protests }\end{array}$ & 2.72 & .95 & 299 \\
\hline $\begin{array}{l}\text { Consider giving money to environmental } \\
\text { organizations }\end{array}$ & 2.01 & .85 & 300 \\
\hline $\begin{array}{l}\text { Consider doing volunteer work for environmental } \\
\text { groups } \\
\text { Consider writing letters to officials regarding }\end{array}$ & 2.36 & .87 & 302 \\
\hline environmental issues & 2.40 & .86 & 297 \\
\hline $\begin{array}{l}\text { Consider being more environmentally friendly if } \\
\text { you were in charge of policies }\end{array}$ & 1.89 & .91 & 287 \\
\hline $\begin{array}{l}\text { Avoid purchasing products from companies that } \\
\text { pollute environment }\end{array}$ & 2.01 & .68 & 298 \\
\hline $\begin{array}{l}\text { Avoid purchasing of certain foods because of the } \\
\text { chemicals used }\end{array}$ & 1.99 & .75 & 295 \\
\hline Buy reduced packaging products & 1.87 & .58 & 288 \\
\hline $\begin{array}{l}\text { Buy products made of recycled materials } \\
\text { whenever possible }\end{array}$ & 1.65 & .62 & 296 \\
\hline Avoid using aerosol spray cans & 1.76 & .75 & 295 \\
\hline Concern for the environment & 1.25 & .45 & 290 \\
\hline $\begin{array}{l}\text { Patronize businesses that have environmentally } \\
\text { friendly practices }\end{array}$ & 1.69 & .61 & 289 \\
\hline $\begin{array}{l}\text { Think businesses are more environmentally } \\
\text { friendly than ten years back }\end{array}$ & 1.90 & .57 & 289 \\
\hline Want to know more about the environment & 1.56 & .63 & 286 \\
\hline $\begin{array}{l}\text { Environmental issues should be given number one } \\
\text { priority }\end{array}$ & 1.70 & .61 & 291 \\
\hline
\end{tabular}

Likert-type scale was used: $1=$ always; $2=$ sometime; $3=$ rarely; and $4=$ never. 
environmental issues, environmentally friendly buying habits, etc. are presented in Table 11. The mean rating on each of the twenty behavior items showed an overwhelming majority of the respondents practiced environmentally positive behavior pattern. The mean rating for recycling ranged from 1.20 (practice to recycle paper) to 1.77 (practice to recycle oil). Buying patterns were found to be environmentally friendly, with respondents buying products made from recycled materials $(\bar{x}=1.65)$, buy reduced packaging products $(\bar{x}=$ 1.87), and avoid purchase of aerosol spray cans $(\bar{x}=1.76)$. A strong concern for the environment was evident $(\bar{x}=1.25)$. An overwhelming majority also supported that environmental issues should be given priority and showed preference for patronizing business that have environmentally friendly practices. Participatory behavior like protests $(\bar{x}=2.72)$, writing letters $(\bar{x}=2.40)$ and volunteer work $(\overline{\mathrm{x}}=$ 2.36), were found to be practiced sometimes.

\section{Travel Motivation}

The responses of travel motivations based on seek and escape dimensions are shown in Table 12. A strong inclination for educational, natural and participatory experiences was evident from participation in outdoor activities $(\bar{x}=1.51)$, experience unpolluted natural settings $(\bar{x}=1.65)$, enjoy purposeful travel $(\bar{x}=1.64)$, learn more about nature $(\bar{x}=1.70)$, learn about the flora and fauna $(\bar{x}=1.75)$, learn about other cultures $(\bar{x}=2.06)$ and learn about local lifestyles $(\bar{x}=2.12)$. Escape motivations were evident from responses to change 
Table 12 DESCRIPTIVE ANALYSIS OF TRAVEL MOTIVATION

\begin{tabular}{lrrr}
\hline Travel Motivation Items & Mean & SD & $\begin{array}{c}\text { No. of } \\
\text { responses }\end{array}$ \\
\hline Get away from the demands of life & 2.10 & 1.31 & 307 \\
Relax and do nothing & 3.39 & 1.35 & 311 \\
Get away from crowds & 2.35 & 1.33 & 307 \\
Change from the routine & 1.80 & 1.07 & 304 \\
Change of pace from every day life & 1.74 & 1.04 & 306 \\
Get away from commercial tourists spots & 1.85 & 1.12 & 305 \\
Enjoy purposeful travel & 1.64 & .97 & 308 \\
Try new foods & 2.83 & 1.45 & 309 \\
I am curious & 1.65 & 1.04 & 302 \\
Rediscover myself & 3.15 & 1.36 & 309 \\
Daring and adventuresome & 2.27 & 1.26 & 305 \\
Participate in outdoor activities & 1.51 & .88 & 305 \\
Know more about the environment & 1.86 & .93 & 317 \\
Learn about the flora / the fauna & 1.75 & .94 & 315 \\
Learn more about nature & 1.70 & .90 & 316 \\
Learn about other cultures & 2.06 & 1.10 & 313 \\
Learn about local lifestyles & 2.12 & 1.80 & 313 \\
Experience unpolluted natural settings & 1.65 & .98 & 310 \\
Visit historical/cultural sites /monuments & 2.30 & 1.24 & 310 \\
Enjoy with my family & 2.83 & 1.65 & 306 \\
Be with my friends & 3.08 & 1.49 & 306 \\
Meet people from different cultures & 2.28 & 1.18 & 313 \\
Learn host country language & 3.51 & 1.34 & 308 \\
Be with people of similar interests & 2.43 & 1.27 & 308 \\
Participate in local entertainment & 3.35 & 1.35 & 307 \\
Be by myself & 3.50 & 1.47 & 312 \\
& & & \\
\hline & & &
\end{tabular}

Likert-type scale was used to measure each item: 1 = very important; 2 = somewhat important; $3=$ unsure; $4=$ not very important; and $5=$ not-at-all important. 
Table 13 DESCRIPTIVE ANALYSIS OF VALUE DIMENSION

\begin{tabular}{lccc}
\hline Value items & Mean & SD & $\begin{array}{c}\text { No. of } \\
\text { responses }\end{array}$ \\
\hline $\begin{array}{l}\text { Ecotourist services costs more than } \\
\text { regular tourist services }\end{array}$ & 4.15 & 1.67 & 314 \\
$\begin{array}{l}\text { Customers do not expect to pay more } \\
\text { than regular tourism services }\end{array}$ & 3.98 & 1.59 & 313 \\
$\begin{array}{l}\text { Use part of the profits to educate the } \\
\text { customers/locals about environmental } \\
\text { issues }\end{array}$ & 5.43 & 1.40 & 312 \\
$\begin{array}{l}\text { Provide environmentally friendly services } \\
\text { at a reasonable cost }\end{array}$ & 5.53 & 1.29 & 310 \\
$\begin{array}{l}\text { Use part of the profits to benefit } \\
\text { community projects }\end{array}$ & 5.26 & 1.48 & 312 \\
\hline
\end{tabular}


from routine $(\overline{\mathrm{x}}=1.80)$, change of pace from every day life, and get away from commercial tourists spots $(\bar{x}=1.85)$. Whereas, to be by myself $(\bar{x}=3.50)$ and relax and do nothing $(\bar{x}=3$. 39) were not very important motivations to travel for these ecotourists.

\section{Value Dimension}

Descriptive analysis for value dimension are presented in Table 13. It included both the cost of services and educate/benefits to the host community attributes. Education/Benefits to the community attributes each had a mean score of above 5.26. Ecotourists' somewhat agreed to cost of ecotourist services being more than regular tourist services with a mean score of 4.15 , and were somewhat undecided about customers do not expect to pay more than regular tourist service which had a mean score of 3.98 .

\section{Service Quality Expectation}

Table 14 shows the statistics of the service quality expectation construct. It consisted of 30 items reflecting the tangibility, responsiveness, reliability, assurance and empathy dimensions. It was measured on a seven point Likerttype scale, ranging from 1 "strongly disagree" to 7 "strongly agree." The first three service expectation statements, equipment that minimize environmental degradation $(\overline{\mathrm{x}}=6.30)$, facilities appropriate to the environment $(\overline{\mathrm{x}}=6.30)$ and facilities environmentally safe $(\bar{x}=6.29)$ had the highest mean score indicating a strong 
Table 14 DESCRIPTIVE ANALYSIS OF ECOSERV (Service Quality Expectation)

\begin{tabular}{llll}
\hline Service Quality Expectation Items & Mean & $\begin{array}{c}\text { No. of } \\
\text { resp. }\end{array}$ \\
\hline
\end{tabular}

Equipment that minimizes environmental degradation

$6.30 \quad 1.36 \quad 319$

Facilities will be appropriate to the environment.

$6.30 \quad 1.36 \quad 318$

Facilities will be environmentally safe

$\begin{array}{lll}6.29 & 1.31 \quad 317\end{array}$

Facilities will be visually appealing

Facilities will be located in an unpolluted environment

Facilities will reflect local influence

Facilities will provide local entertainment

Employees will be neat-appearing in local attire

Employees will be neat-looking in comfortable attire

Materials (pamphlets or statements) will be visually appealing

Materials (pamphlets or statements) will reflect local influence

Employees will tell you exactly when services will be performed.

Employees will give prompt service to customers

Employees will always be willing to help customers

Employees will never be too busy to respond to customers' requests

When promise to do something by certain time, they will do so

$\begin{array}{lll}5.10 & 1.39 & 317\end{array}$

$5.34 \quad 1.45 \quad 315$

$\begin{array}{lll}5.58 & 1.35 \quad 316\end{array}$

$\begin{array}{lll}4.51 & 1.56 \quad 318\end{array}$

$4.50 \quad 1.46 \quad 316$

$\begin{array}{lll}5.17 & 1.28 & 317\end{array}$

$\begin{array}{lll}4.93 & 1.33 \quad 316\end{array}$

$\begin{array}{lll}5.06 & 1.36 \quad 315\end{array}$

$5.34 \quad 1.44 \quad 313$

$\begin{array}{lll}5.57 & 1.34 & 314\end{array}$

$\begin{array}{lll}5.82 & 1.43 \quad 313\end{array}$

$\begin{array}{lll}5.50 & 1.39 & 311\end{array}$

$\begin{array}{lll}5.64 & 1.40 \quad 308\end{array}$

Likert-type scale was used to measure items:

1 -Strongly disagree to 7 - Strongly agree 
Table 14 DESCRIPTIVE ANALYSIS OF ECOSERV (Contd.)

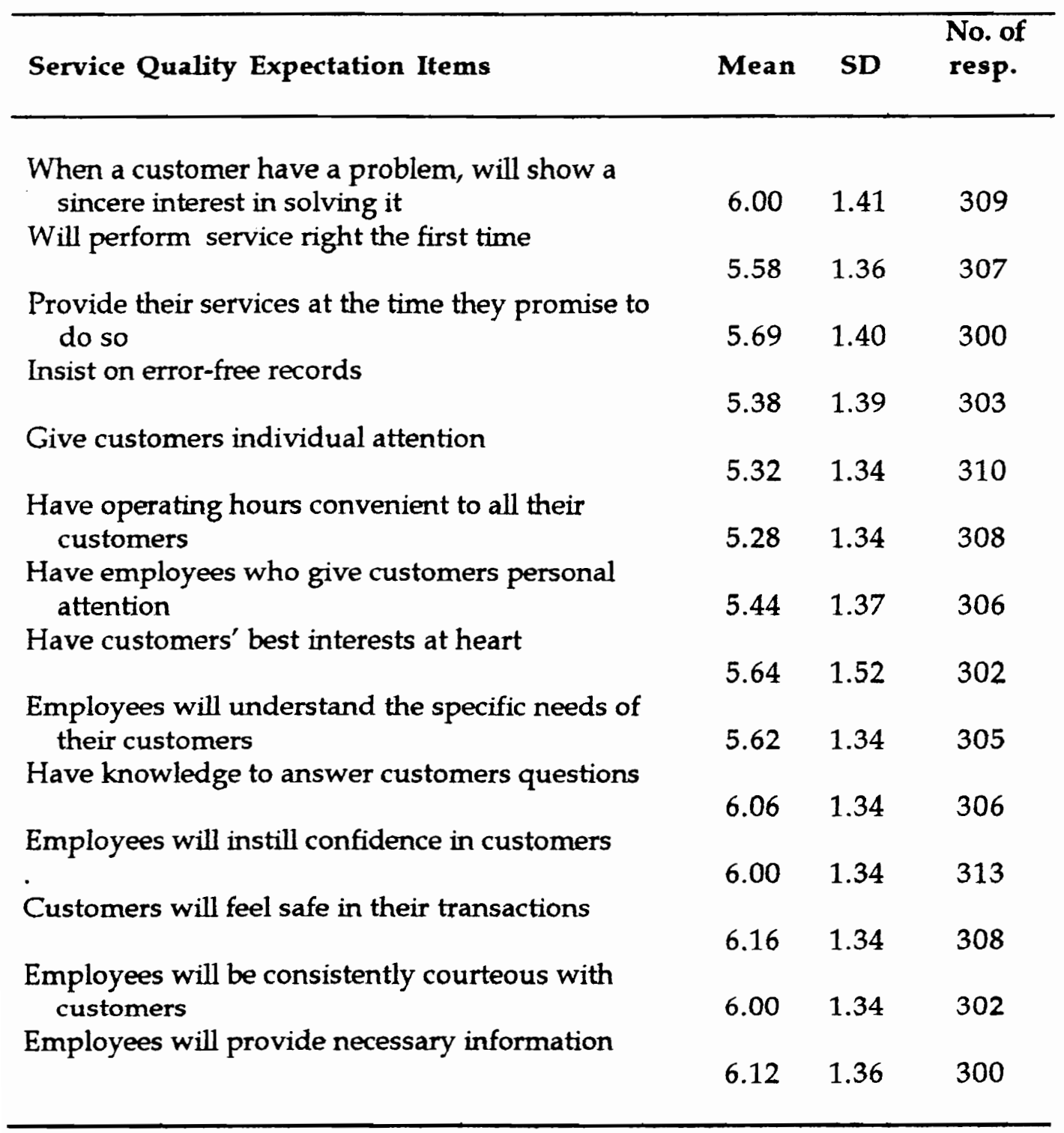

Likert-type scale was used to measure items:

1 -Strongly disagree to 7 - Strongly agree 
inclination toward environmental consciousness. Services related to employees that were very important to respondents were, customers feel safe in transaction ( $\mathrm{x}$ $=6.16)$, provide necessary information $(x=6.12)$, consistently courteous $(x=6.00)$, instill confidence $(x=6.00)$, and sincere interest in solving customers problems $(x=$ $6.00)$.

\section{NON-RESPONSE BIAS}

Possible non-response biases were addressed by comparing the responses of the early respondents to those of the late respondents. According to Armstrong and Overton (1977) such comparisons are often similar and are commonly used for testing. Early responses $(n=35)$ were received on June 9 and June 10, 1996. Late responses were received between August 10 and August 30, 1996. Appendix (6) shows comparisons between the early responses and late responses on selected demographic and behavior variables. Chisquare and t-tests performed revealed that the two groups were not significantly different, thereby addressing the non-response bias. T-tests done on sixteen selected behavior variables for the two groups showed the groups were significantly different for "glass" and "serv1." For the other fourteen variables the groups were found to be similar with no significant differences revealed. The Chi-square tests performed on the two groups showed no significant difference for age and gender variable. 


\section{VALIDITY AND RELIABILITY TESTS}

Validity is the degree to which the instrument is measuring what it purports to measure (Kerlinger, 1986). Reliability on the other hand refers to the degree to which observations are consistent and stable (Rosenthal and Rosnow, 1984).

Nomological validity was established while developing theoretical rationale and research hypotheses. The face or content validity of the instrument was checked by conducting a three-step pilot study. The survey questionnaire was given to selected faculty, students and ecotourists for feedback regarding wording, layout, and comprehension of the items, before it was considered ready to be administered to the final sample.

Reliability of an instrument indicates its stability or consistency over repeated measures. To enhance reliability of the instrument the NEP (attitude), environmental behavior, travel motivation and service quality expectation (SERVQUAL) scales were selected from previously applied and tested scales whose reliability coefficients are well established. However, in the context of this study (except NEP scale) other scales were adapted based on ecotourism literature and recommendations of the focus group. To rule out any possible variations reliability coefficients were calculated. A coefficient alpha (Cronbach alpha) tests the internal consistency of the items in relation to a 
single trait within the instrument (Nunnally 1978). The obtained alpha values are presented in Table 15. A coefficient alpha of 0.70 or higher is considered to be adequately reliable for group data purpose. All of the instrument's reliability scores were 0.80 or higher, except the value dimension score which was 0.59 . Value measures were factor analyzed to delineate any underlying dimensions and the factor groupings were checked for reliability.

Convergent validity pertains to the extent to which scale items assumed to represent a construct do in fact "converge" on the same construct (Parasuraman et al. 1991). The reliability of a scale as measured by coefficient alpha reflects the degree of cohesiveness among the scale items and is therefore an indirect indicator of convergent validity. The coefficient alpha values of NEP (attitude), environmental behavior, travel motivation, value and service quality expectation scales were found to be fairly high as mentioned earlier.

A more stringent test of convergent validity is whether scale items expected to load together in a factor analysis actually do so. Factor analyses of NEP (attitude), environmental behavior, travel motivation, value dimension and service quality expectation scales were conducted to further check the validity and reliability. 
Table 15 RELIABILITY COEFFICIENT FOR ATTITUDE, BEHAVIOR, MOTIVATION, VALUE AND

SERVICE QUALITY EXPECTATION SCALES

\begin{tabular}{lcc}
\hline Scales & $\begin{array}{c}\text { No. of } \\
\text { Items }\end{array}$ & $\begin{array}{c}\text { Alpha } \\
\text { Value }\end{array}$ \\
\hline NEP (attitude scale) & 15 & .8463 \\
Behavior Scale & 20 & .8169 \\
Travel Motivation Scale & 26 & .8430 \\
Value Dimension Scale & 5 & .5904 \\
ECOSERV (service expectation scale) & 30 & .9694 \\
\hline
\end{tabular}




\section{FACTOR ANALYSIS}

Factor analysis is a statistical approach that can be used to analyze interrelationships among a large number of variables and to explain these variables in terms of their common underlying dimensions (factors). It condenses the information contained in a number of variables into a smaller set of dimensions (factors) with a minimum loss of information (Hair, Anderson, Tatham, and Black, 1992). Factor analysis was performed on NEP (attitude), environmental behavior, travel motivation, value dimension and service quality expectation variables. Factor groups based on these analyses were subsequently used in correlation coefficient and canonical correlation analyses to examine the relationship between independent variables (attitude, behavior, travel motivation and value) and dependent variables (service quality expectation).

\section{Environmental Attitude (NEP) Factor Analysis}

First the fifteen NEP statements were factor analyzed to delineate underlying dimensions of environmental concerns in the context of ecotourist attitude toward the environment. Results of factor analysis and related statistics are presented in Table 16. Three NEP subscales were generated after varimax rotation namely: Fragility of Nature's Balance (alpha reliability $=.72$ ); Rejection of Anthropocentrism (alpha reliability = .69); and Limits to Growth (alpha reliability $=.70)$. All of the three NEP subscales had an eigen value greater 


\section{Table 16 FACTOR ANALYSIS OF ENVIRONMENTAL ATTITUDE (NEP)}

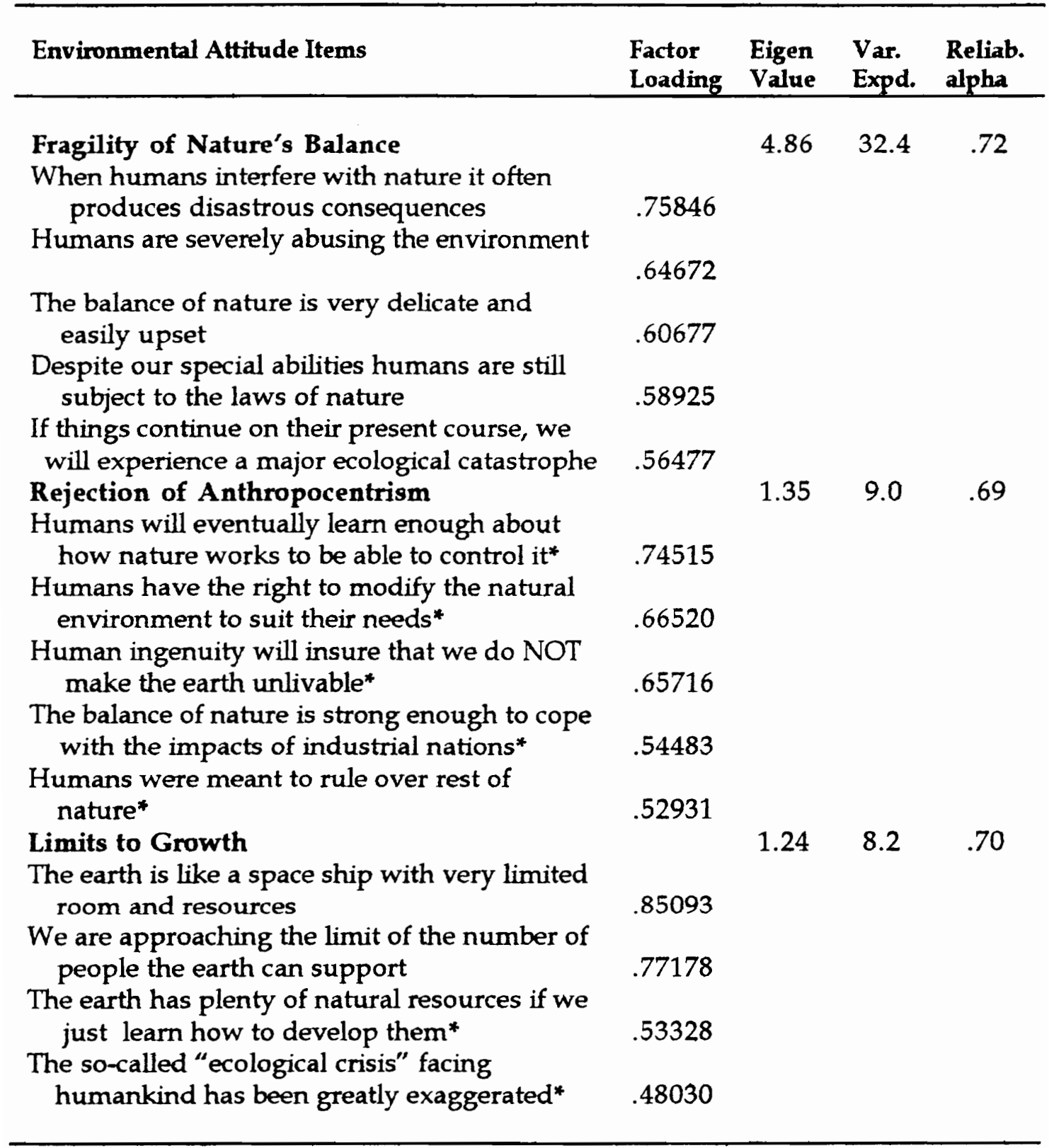

1 = strongly agree; 2 = somewhat agree; 3 = neutral; 4 = somewhat disagree; and $5=$ strongly disagree. Note: ${ }^{*}$ items were reverse coded

Var. Expd. (Variance Explained); Reliab. (Reliability) 
than one. Fragility of Nature's Balance factor grouping consists of statements which express the belief that human interference with nature often produces disastrous consequences; humans are severely abusing the environment; balance of nature is very delicate; humans are subject to the laws of nature; and we will experience a major ecological catastrophe if things continue on their present course. Item "plants and animals have as much right as humans to exist" loaded on the first factor grouping without any factor loading, therefore this item was eliminated.

The subscale Rejection to Anthropocentrism consists of statements which express beliefs that humans will be able to control nature, humans have a right to modify the natural environment, balance of nature is strong enough to cope with industrial growth, and humans were meant to rule over nature. These items were reversed coded so any disagreement with them indicated rejection of anthropocentric worldview. The third subscale consisted of statements which express a belief that the earth has limited resources and that we are approaching the limit of number of people the earth can support. It also showed a negative attitude toward statements relating to earth having plenty of natural resources and the so-called ecological crisis facing mankind has been greatly exaggerated (these two statements were reverse coded *), therefore any disagreement is interpreted as agreement with ecological worldview. The last item regarding ecological crisis loaded on two factors. 


\section{Environmental Behavior Factor Analysis}

The factor analysis results of environmental behavior and associated statistics are presented Table 17. Varimax rotation generated six factors with eigen values greater than one, namely: Practice to Recycle (alpha reliability $=$ $.82) ;$ Concerns for the Environment (alpha reliability $=.69$ ); Involvement in Environmental Issues (alpha reliability $=.76$ ); Environmentally Friendly Buying Habits (alpha reliability $=.64$ ); Environmentally Friendly Avoidance (alpha reliability $=.67$ ); and Friendly Business. These six factor groupings combined, explained apparently 62 percent of the variance. Moreover, most of the factor loading were greater than .60 , implying a reasonably high correlation between the delineated factors and their individual items. Behavior item "consider giving money to the organizations" loaded on Concerns for the Environment and also on Involvement in the Enoironment Issues factor.

\section{Travel Motivation Factor Analysis}

The twenty-six motivation items were factor analyzed to delineate the underlying dimensions. Travel motivation factor analysis and associated statistics are presented in Table 18. Varimax rotation resulted in six factors with eigen values greater than one. The factors were labeled as: Intercultural (alpha reliability $=.83$ ); Escape (alpha reliability $=.81$ ); Education (alpha reliability $=.82) ;$ Excitement/Thrills (alpha reliability $=.44$ ); Get Away (alpha reliability $=.37$ ); and Satisfaction (alpha reliability $=.60$ ). Combined these 


\begin{tabular}{|c|c|c|c|c|}
\hline Environmental Behavior Items & $\begin{array}{c}\text { Factor } \\
\text { Loading }\end{array}$ & $\begin{array}{l}\text { Eigen } \\
\text { Value } \\
\end{array}$ & $\begin{array}{l}\text { Var. } \\
\text { Expd. }\end{array}$ & $\begin{array}{c}\text { Reliab. } \\
\text { alpha }\end{array}$ \\
\hline $\begin{array}{l}\text { Practice to Recycle } \\
\text { recycling of glass } \\
\text { recycling of plastic } \\
\text { recycling of paper } \\
\text { recycling of cans }\end{array}$ & $\begin{array}{l}.84013 \\
.83106 \\
.77320 \\
.71427\end{array}$ & 5.01 & 25.1 & .82 \\
\hline $\begin{array}{l}\text { Concerns for the Environment } \\
\text { concern for the environment } \\
\text { environmental issues should be given priority } \\
\text { know more about the environment } \\
\text { consider giving money to organizations }\end{array}$ & $\begin{array}{l}.71634 \\
.64653 \\
.62463 \\
.59538\end{array}$ & 2.41 & 12.1 & .69 \\
\hline $\begin{array}{l}\text { Involvement in Environmental Issues } \\
\text { consider doing volunteer work for groups } \\
\text { consider participation in protests } \\
\text { consider writing letters } \\
\text { consider being more environmentally friendly }\end{array}$ & $\begin{array}{l}.77807 \\
.70987 \\
.65226 \\
.50258\end{array}$ & 1.42 & 7.1 & .76 \\
\hline $\begin{array}{l}\text { Environmentally Friendly Buying Habits } \\
\text { avoid use of aerosol spray cans } \\
\text { buy products made of recycled materials } \\
\text { buy reduced packaging products } \\
\text { patronize environmentally friendly businesses }\end{array}$ & $\begin{array}{l}.74455 \\
.57241 \\
.55460 \\
.51043\end{array}$ & 1.23 & 6.1 & .64 \\
\hline $\begin{array}{l}\text { Environmentally Friendly Avoidance } \\
\text { avoid purchase of certain foods because of } \\
\text { chemicals } \\
\text { avoid purchase products from companies that } \\
\text { pollute }\end{array}$ & $\begin{array}{l}.83422 \\
.69827\end{array}$ & 1.14 & 5.7 & .67 \\
\hline $\begin{array}{l}\text { Friendly Business } \\
\text { businesses are more environmentally friendly } \\
\text { than ten years back }\end{array}$ & .86152 & 1.07 & 5.4 & \\
\hline TOTAL VARIANCE EXPLAINED & & & 61.5 & \\
\hline
\end{tabular}

Likert-type scale was used to measure each item: $1=$ always; $2=$ sometime; $3=$ rarely; and $4=$ never.

Var. Expd. (Variance Explained); Reliab. (Reliability) 
Table 18 FACTOR ANALYSIS OF TRAVEL MOTIVATION

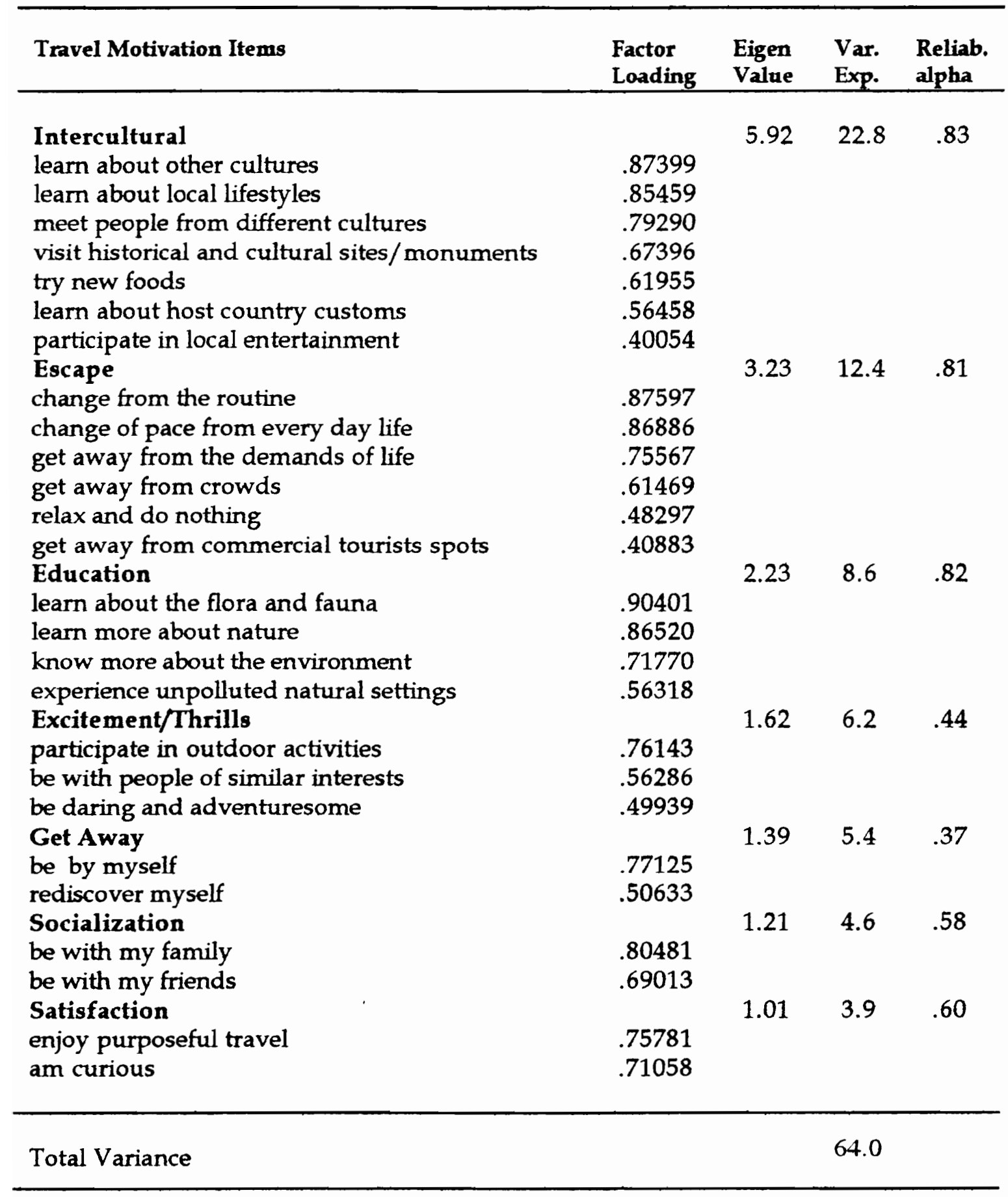

Likert-type scale was used to measure each item: $1=$ very important; $2=$ smoewhat important; 3=unsure; 4=not very important; and 5=not-at-all important.

Var. Expd. (Variance Explained); Reliab. (Reliability) 
Table 19 FACTOR ANALYSIS OF VALUE DIMENSION

\begin{tabular}{|c|c|c|c|c|}
\hline Value Items & $\begin{array}{l}\text { Factor } \\
\text { Loading }\end{array}$ & $\begin{array}{l}\text { Eigen } \\
\text { Value }\end{array}$ & $\begin{array}{l}\text { Var. } \\
\text { Expd. }\end{array}$ & $\begin{array}{l}\text { Reliab. } \\
\text { alpha }\end{array}$ \\
\hline $\begin{array}{l}\text { Educate/Benefit Community } \\
\text { Use part of the profits to educate the } \\
\text { customers/locals about environmental issues }\end{array}$ & .91163 & 2.35 & 47.1 & .83 \\
\hline $\begin{array}{l}\text { Use part of the profits to benefit community } \\
\text { projects }\end{array}$ & .87318 & & & \\
\hline $\begin{array}{l}\text { Provide environmentally friendly services at a } \\
\text { reasonable cost }\end{array}$ & .79649 & & & \\
\hline $\begin{array}{l}\text { Cost of Services } \\
\text { Customers do not expect to pay more than } \\
\text { regular tourism services }\end{array}$ & .81975 & 1.38 & 27.7 & .92 \\
\hline $\begin{array}{l}\text { Ecotourist services costs more than regular } \\
\text { tourist services }\end{array}$ & $.79579 *$ & & & \\
\hline TOTAL VARIANCE EXPLAINED & & & 74.8 & \\
\hline
\end{tabular}

Note: ${ }^{\text {item }}$ was reverse coded

Var. Expd. (Variance Explained); Reliab. (Reliability) 
factor groupings accounted for 64 percent of the total variance. Most of the factor loading were greater than .60 , implying a reasonably high correlation between the delineated factors and their individual items. Two items loaded on two factors, "get away from crowds" loaded on Escape and Get Away factors, and "be daring and adventuresome" loaded on Excitement/Thrills and Get Away factors.

\section{Value Dimension Factor Analysis}

Value items were also factor analyzed to delineate the underlying dimensions, and the statistics are shown in Table 19. Varimax rotation resulted in two factor groupings with eigen values greater than one. The factors were labeled as: Educate/Benefits to the Community (alpha reliability $=.83$ ); and Costs of Services (alpha reliability $=.92$ ). Item "ecotourist services costs more than regular services" was reverse coded so any disagreement was interpreted as agreement with the statement. These two factor groupings explained a total variance of 74.8 percent. Moreover, most of the factor loadings were greater than .70 , implying a very high correlation between the delineated factors and their individual items.

ECOSERV (service quality expectation) Factor Analysis

To verify the dimensionality of 30 items in ECOSERV (adapted SERVQUAL) scale, these items were too factor analyzed. Because SERVQUAL 
(22 items), was hypothesized to have a five-dimensional structure, the adapted version ECOSERV ( 30 items) was constrained a priori to six factors. The sixfactor solution was subjected to varimax rotation. The factor analysis and associated statistics are presented in Table 20 . The six factors were labeled as: Empathy; Eco-Tangibles; Responsiveness; Tangibles; Assurance; and Reliability.

The overall factor loading pattern is similar to the original SERVQUAL scale with very few exceptions. The Tangibles factor which was unidimensional in the original scale (Parasuraman et al., 1988), splits into two subdimensions in the revised scale - one pertaining to physical facilities /equipment and another to employees/communication materials (Parasuraman et al. 1991). In this study the Tangibles factor splits in two dimensions namely Eco-Tangibles and Tangibles. The former pertaining to facilities and equipment that minimize environmental degradation, and the latter to employees and communication materials. The degree of overlap among dimensions in the revised scale was somewhat higher than the original scale. Therefore the overlap among some dimensions in this study is consistent with the earlier findings. An Item "provide necessary information" that was added to this scale based on the recommendation of focus group, loaded on Assurance factor grouping. Item "show sincere interest in solving a problem" loaded on Responsiveness and Reliability factors. The factor pattern of the ECOSERV used in this study appears to be stable. 
Table 20 FACTOR ANALYSIS OF SERVICE QUALITY EXPECTATION

\begin{tabular}{|c|c|c|c|c|}
\hline Service Quality Expectation Items & $\begin{array}{l}\text { Factor } \\
\text { Loading } \\
\end{array}$ & $\begin{array}{l}\text { Eigen } \\
\text { Value } \\
\end{array}$ & $\begin{array}{l}\text { Var. } \\
\text { Expd. }\end{array}$ & $\begin{array}{l}\text { Reliab } \\
\text { alpha }\end{array}$ \\
\hline Empathy & & 17.05 & 56.8 & .93 \\
\hline personal attention & .82340 & & & \\
\hline individual attention & .73249 & & & \\
\hline operating hours convenient & .66764 & & & \\
\hline understand specific needs & .60025 & & & \\
\hline Eco-Tangibles & & 1.49 & 5.0 & .95 \\
\hline facilities appropriate to the environment & .87413 & & & \\
\hline equipment that minimizes degradation & $\begin{array}{l}.86047 \\
73909\end{array}$ & & & \\
\hline Responsiveness & & 1.06 & 3.6 & .93 \\
\hline employees always be willing to help & .64670 & & & \\
\hline employees give prompt service to customers & .55652 & & & \\
\hline employees never be too busy to help & .50880 & & & \\
\hline employees tell exactly when service will be & .43463 & & & \\
\hline Tangibles & & .79 & 2.7 & .86 \\
\hline materials reflect local influence & .62658 & & & \\
\hline provide local entertainment & .62606 & & & \\
\hline materials visually appealing & .61747 & & & \\
\hline facilities visually appealing & .60058 & & & \\
\hline employees in local attire & .58888 & & & \\
\hline facilities reflect local influence & .56477 & & & \\
\hline employees in comfortable attire & .51442 & & & \\
\hline facilities in unpolluted setting & .42478 & & & \\
\hline Assurance & & .67 & 2.2 & .98 \\
\hline feel save in their transaction & .62723 & & & \\
\hline provide the necessary information & .59867 & & & \\
\hline have knowledge to answer questions & .56408 & & & \\
\hline instill confidence in customers & .54250 & & & \\
\hline consistently courteous with the customers & .53471 & & & \\
\hline Reliability & & .65 & 2.2 & .94 \\
\hline provide services at promised time & .71452 & & & \\
\hline promise to do service by certain time & .64856 & & & \\
\hline perform the service right the first time & .62171 & & & \\
\hline insist error-free service & .49259 & & & \\
\hline show sincere interest in solving a problem & .42971 & & & \\
\hline
\end{tabular}

Likert-type scale was used to measure items:1 - Strongly disagree to 7 - Strongly agree Var. Expd. (Variance Explained); Reliab. (Reliability) 
The delineated ECOSERV factor groupings had a relatively high reliability alpha coefficients ranging from .98 (Assurance), .95 (Eco-Tangibles), .94 (Reliability), .93 (Responsiveness), .93 (Empathy) to .86 (Tangibles). Combined these factor groupings accounted for 72.5 percent of the total variance. 


\section{HYPOTHESIS TESTING}

This section reports the results of the statistical tests performed to test the research hypotheses. Hypothesis 1 to Hypothesis 4 were tested by using Pearson's correlation coefficient analysis on factor groupings of both the independent and dependent variables. Hypothesis 5 was tested by utilizing canonical correlation analysis. Factor groupings based on factor analysis were used for a set of independent and dependent variables. The dependent variable used was ECOSERV (service quality expectation), which consisted of six factor groupings, namely, Tangibles, Reliability, Assurance, Responsiveness, Empathy and Eco-Tangibles. The independent factor groupings will be mentioned in the appropriate analysis.

Hypothesis 6 was tested by using one-way analysis of variance followed by Duncan's multiple range test if there was any significance, and $t$-tests. Each research question and null hypothesis is reiterated below, and then the results of the statistical analysis are reported. 


\section{Research Question 1:}

Is ecotourists' environmental attitude associated with ecotourists' service quality expectation dimension?

\section{Hypothesis 1:}

There is no significant relationship between environmental attitude and service quality expectations of the ecotourists.

To test the above hypothesis Pearson's correlation coefficient analysis was performed to investigate the relationship between two sets of variables: NEP (environmental attitude) and ECOSERV. The three attitude factors were: Fragility of Nature's Balance, Rejection of Anthropocentricism and Limits to Growth.

The results of correlation analysis (Table 21) showed that there were some significant relationships found between selected environment attitude factors and selected service quality expectation factors, thus revealing partial support for the hypothesis. The service factor that revealed significant but moderate correlation with all three attitude factors was Eco-Tangibles, and the correlation coefficients ranged from .22 to .30 . Eco-Tangibles refer to facilities that are appropriate to the environment, equipment that minimizes environmental degradation and facilities that are environmentally safe. It can be interpreted that a pro-environmental attitude might prefer services that are environmentally appropriate. A closer examination of the results showed 
Table 21 CORRELATION COEFFICIENT ANALYSIS

SERVICE QUALITY EXPECTATION FACTORS

AND ENVIRONMENTAL ATTITUDE FACTORS

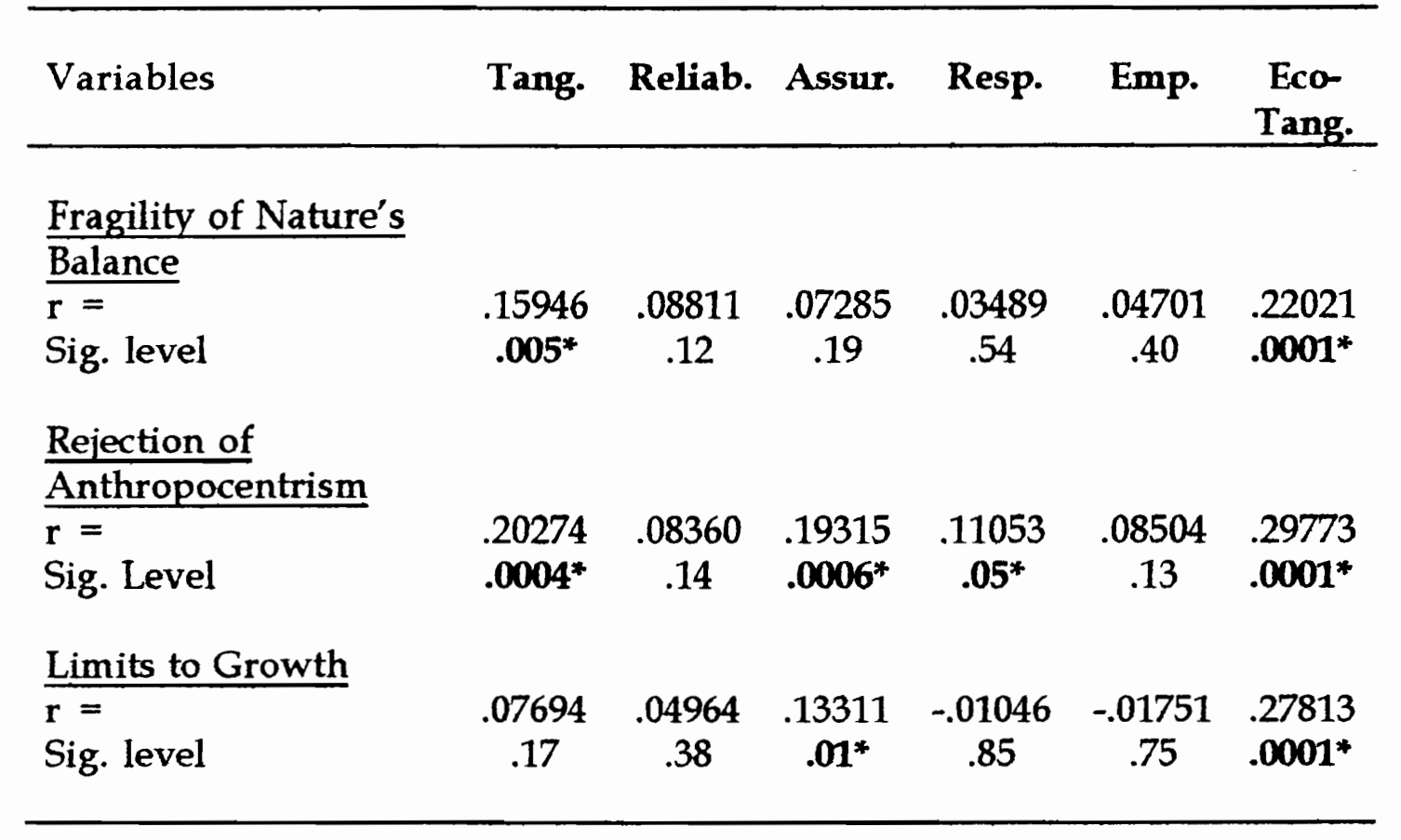

Tang. (Tangibles); Reliab. (Reliability); Assur. (Assurance); Resp. (Responsibility); Emp. (Empathy); Eco-Tang. (Eco-Tangibles);

$\left({ }^{*}\right)$ denotes significance at the 0.05 or better probability level 
some significant but modest relations between the two factor groupings. Service factor Tangibles was correlated with two attitude factors, namely, Fragility of Nature's Balance and Rejection of Anthropocentricism, and Responsiveness was found to be correlated with one and Assurance with two attitude factors respectively. The only service factor that did not show any significant relationship with the three attitude factors was Empathy. 


\section{Research Question 2:}

Is ecotourists' environmental behavior associated with ecotourists' service quality expectation dimension?

\section{Hypothesis 2:}

There is no significant relationship between environmental behavior and service quality expectations of the ecotourists.

The above hypothesis was tested using Pearson's correlation coefficient analysis to investigate the relationship between two sets of variables: environmental behavior and ECOSERV. The six environmental behavior factors used in this analysis were: Practice to Recycle, Concerns for the Environment, Involvement in Environmental Issues, Environmentally Friendly Buying Habits, Environmentally Friendly Avoidance, and Friendly Business.

Table 22 presents the correlation between service quality expectation factor groups and environmental behavior factor groups, and indicate nine significant correlations. Hypothesis 2 was rejected for the nine correlations, though the coefficient levels were fairly modest to moderate (.11 to .23). Environmental behavior factors like the environmental attitude factors (in hypothesis 1) showed a consistently positive relationship with Eco-Tangible service quality factor. Comparatively the highest coefficient score was attributed to Concerns for the Environment and Eco-Tangibles factor groups (.23). 
Table 22 CORRELATION COEFFICIENT ANALYSIS

SERVICE QUALITY EXPECTATION FACTORS

AND ENVIRONMENTAL BEHAVIOR FACTORS

Variables

Tang. Reliab. Assur. Resp. Emp. EcoTang.

Practice to Recycle

$r=$

$\begin{array}{lllllll}.14232 & .10516 & .12310 & .06218 & .07984 & .18128\end{array}$

Sig. level

$\begin{array}{lllllll}.01^{*} & .06 & .02^{*} & .27 & .15 & .001^{*}\end{array}$

Concerns for the

Environment

$\mathrm{r}=$

Sig. level

$\begin{array}{cccccc}.11388 & -.03145 & .07231 & .01020 & .00087 & .22531 \\ .04 * & .58 & .20 & .85 & .98 & .0001^{*}\end{array}$

Involvement in

Environmental Issues

$\mathbf{r}=$

Sig. level

$\begin{array}{cccccc}.07943 & .01166 & .06747 & .00398 & .00950 & .18719 \\ .16 & .84 & .23 & .94 & .86 & .0008^{*}\end{array}$

Environmentally

Friendly Buying Habits $r=$

Sig. level

$\begin{array}{cccccc}.07870 & .01934 & .07395 & -.0121 & .02052 & . \mathbf{1 9 4 3 1} \\ .16 & .73 & .19 & .83 & .83 & \mathbf{. 0 0 0 5 *}\end{array}$

Environmentally

Friendly Avoidance

$\mathrm{r}=$

Sig. level

$\begin{array}{cccccc}.12937 & .04471 & .06331 & .06605 & .02870 & .16729 \\ .02 * & .43 & .26 & .24 & .61 & .002^{*}\end{array}$

Friendly Business

$\mathbf{r}=$

Sig. level

$$
.06162
$$

.27

$$
.05040
$$

.0308

$-.039$

.05136

.00404

.37

.58

.49

.94

Tang. (Tangibles); Reliab. (Reliability); Assur. (Assurance); Resp. (Responsibility); Emp. (Empathy); Eco-Tang. (Eco-Tangibles);

${ }^{*}$ ) denotes significance at the 0.05 or better levels 
Tangibles was another service factor that revealed significant but modest relations with Practice to Recycle, Concerns for the Environment, and Environmentally Friendly Aooidance.

From the results it was evident that behavior factors showed significant correlations with service quality expectation factors that are influenced by environmental features. Once again a clear pro-environmental behavioral pattern is evident from these results. It can be stated that environmentally friendly behavior practices tend to expect services at an ecotourist business to be environmentally appropriate and sustainable. 
Research Question 3:

Are ecotourists' travel motivations associated with ecotourists' service quality expectations dimension?

\section{Hypothesis 3:}

There is no significant relationship between travel motivations and service quality expectations of the ecotourists.

The above hypothesis was tested using Pearson's correlation coefficient analysis to investigate the relationship between two sets of variables: travel motivations and ECOSERV. The six travel motivation factors utilized for this analysis were: Intercultural, Escape, Education, Excitement/Thrills, Get Away, and Socialization

The results of correlation analysis measured across the set of six travel motivation factors and six service quality expectation factors are presented in Table 23. The results reveal six significant relationships with modest to moderate correlation coefficients ranging from .11 to .24 . In this analysis there was a significant relationship found between Education and Eco-Tangibles, both factors emphasizing environmental influence. Tangibles service quality factor was moderately related to three travel motivation factor. Intercultural and Socialization travel motivation factors showed significant correlation with Tangibles. It could be interpreted that when ecotourists travel with family and 
Table 23 CORRELATION COEFFICIENT ANALYSIS

SERVICE QUALITY EXPECTATION FACTORS

AND TRAVEL MOTIVATION FACTORS

Variables

Tang. Reliab. Assur. Resp. Emp. Eco-

Tang.

Intercultural

$\mathrm{r}=$

Sig. level

$\begin{array}{cccccc}.23507 & -.04146 & .02175 & -.00653 & .03272 & .01014 \\ .0001 * & .46 & .70 & .90 & .56 & .85\end{array}$

Escape

$\mathbf{r}=$

Sig. level

$\begin{array}{cccccc}.03972 & .03875 & .03317 & .03128 & .11953 & .01197 \\ .48 & .49 & .55 & .58 & .03^{*} & .83\end{array}$

$\underline{\text { Education }}$

$\mathbf{r}=$

Sig. level

$\begin{array}{cccccc}.01337 & -.00775 & .05768 & .04561 & .06032 & .14349 \\ .81 & .89 & .30 & .41 & .28 & .01^{*}\end{array}$

Excitement/Thrills

$\mathrm{r}=$

Sig. level

$\begin{array}{cccccc}.05671 & .04006 & .04233 & .02666 & .08352 & .05165 \\ .31 & .46 & .45 & .63 & .13 & 35\end{array}$

Get Away

$\mathrm{r}=$

Sig. level

$\begin{array}{cccccc}.11151 & -.02302 & -.04477 & .00332 & .02859 & .00580 \\ .05^{*} & .68 & .42 & .95 & .61 & .9169\end{array}$

Socialization

$\mathbf{r}=$

Sig. Level

$\begin{array}{cccccc}.15196 & .07655 & .054 & .03865 & .16224 & .00271 \\ .007 * & .17 & .33 & .49 & .003^{*} & .96\end{array}$

Tang. (Tangibles); Reliab. (Reliability); Assur. (Assurance); Resp. (Responsibility); Emp. (Empathy); Eco-Tang. (Eco-Tangibles);

${ }^{*}$ ) denotes significance at the 0.05 or better levels 
friends, and are looking for Intercultural learning experiences, they tend to expect ecotourist businesses to provide services and facilities that have local influence.

Empathy which refers to caring, individualized attention the firms provide to its customers, was found to be significantly related to Escape and Socialization travel motives very modestly. Get Away travel motivation factor showed a somewhat fuzzy relationship with Tangibles with a very modest coefficient. Compared to the findings of the previous two hypotheses, the findings here reveal an emphasize on Intercultural and social issues. 


\section{Research Question 4:}

Is ecotourists' value dimension associated with ecotourists' service quality expectation dimension?

\section{Hypothesis 4:}

There is no significant relationship between value dimension and service quality expectations of the ecotourists.

Pearson's correlation coefficient was used to test the above hypothesis to investigate the relationship between two sets of variables: value dimension and ECOSERV. The value variable consisted of two factor groupings: Educate/Benefit the Community and Cost of Services.

The results of correlation coefficient analysis performed on two value dimension factors and six service quality expectation factors are presented in Table 24. The findings reveal that all factors were significantly related with coefficients ranging from .21 to .64 . Also, it was evident that Educate/Benefit to the Community factor was strongly related to service factors than Cost of Services factor. A closer examination indicated that Educate/Benefits to the Community group was strongly related to Assurance service quality expectation factor (.64). It can be interpreted that ecotourists who perceive ecotourist business to use part of its profits to benefit the community and provide environmentally friendly services, tend to expect services that assures trust and confidence. 
Table 24 CORRELATION COEFFICIENT ANALYSIS

SERVICE QUALITY EXPECTATION FACTORS

AND VALUE DIMENSION FACTORS

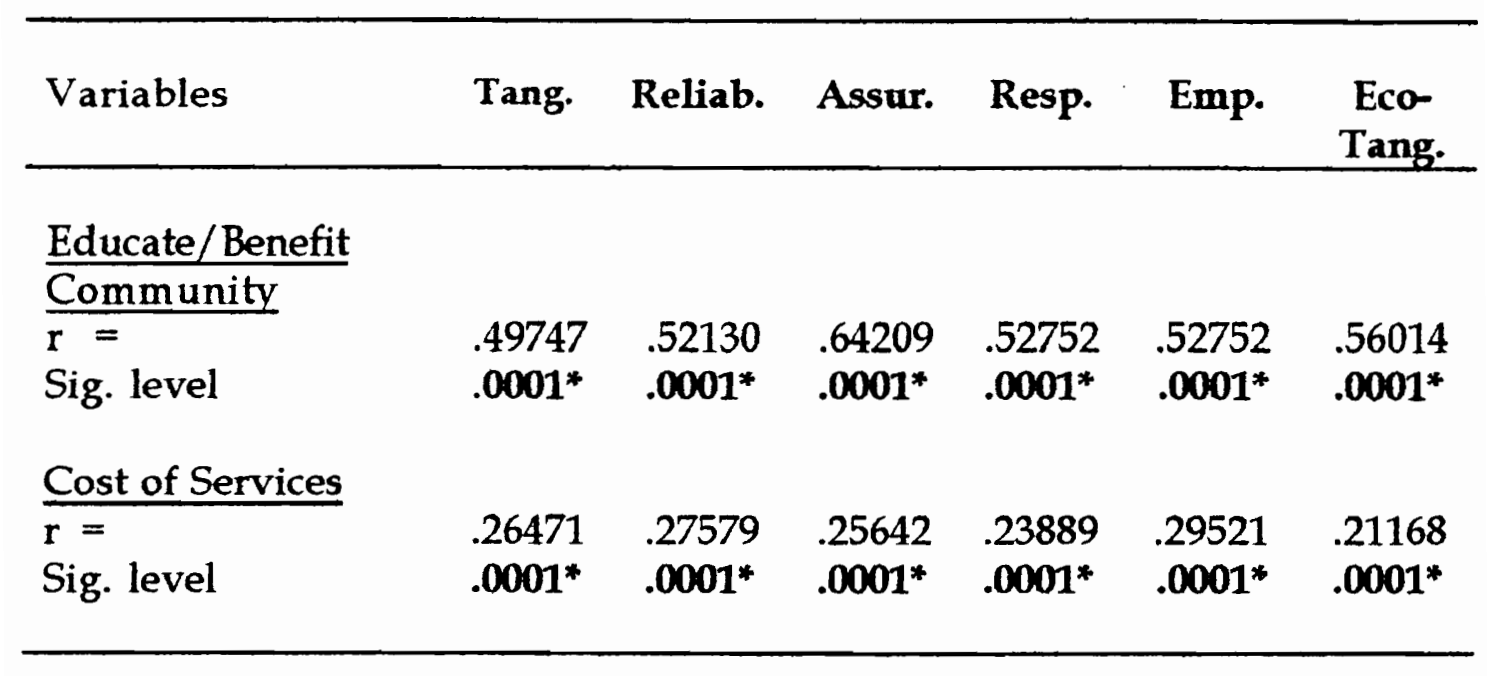

Tang. (Tangibles); Reliab. (Reliability); Assur. (Assurance); Resp. (Responsibility); Emp. (Empathy); Eco-Tang. (Eco-Tangibles);

(*) denotes significance at the 0.05 or better levels 
The findings of the above research hypotheses reveal that environmental attitudes, environmental behaviors, travel motivations or values, there is a clear inclination toward natural and cultural factors was evident. Most of the service quality expectation factors that were found to be significantly related to corresponding factor groups were influenced by environmental issues. Although the coefficient levels were somewhat modest to moderate except for value factors, all correlations were not only positive but environmentally positive.

After a brief discussion on canonical correlation analysis, hypothesis 5 and hypothesis 6 will be discussed. 


\section{CANONICAL CORRELATION ANALYSIS}

Canonical correlation analysis was used to examine the relationship between independent and dependent sets of variables. This analysis was performed since there were multiple dependent and multiple independent variables. Also, this technique was used to identify covariates so that a better feel for the corresponding independent and dependent variables in the study can be gained. Canonical analysis was chosen as a powerful technique for

exploring the relationships among multiple criterion (dependent) and predictor (independent) variables. It can be viewed as a logical extension of multiple regression analysis (Hair et al. 1992). Multiple regression involves a single dependent variable whereas canonical correlation involves multiple dependent variables.

Canonical analysis is a multivariate statistical model that facilitates the study of the interrelationships between multiple criterion variables and a set of multiple predictor variables (Christensen, 1983). It is a method of analyzing the number, magnitude, and composition of independent dimensions of the relationship between two sets of variables. The underlying principle is to develop a linear combination of each set of variables (both independent and dependent) in a manner that maximizes the correlation between the two sets (Hair et al. 1992). The objectives of canonical analyses may include any or all of the following: 
1. Determining whether two sets of variables (measurements made on the same objects) are independent of one another or, conversely, determining the magnitude of relationships that may exit between the two sets.

2. Deriving a set of weights for each set of criterion and predictor variables such that the linear combination themselves are maximally correlated.

3. Deriving additional linear functions that maximize the remaining correlation, subject to being independent of the preceding set (or sets) of linear compounds.

\section{Application of Canonical Correlation}

The basic input data for canonical correlation analysis are two sets of variables. The process derives a linear combination of variables from each of the two sets of variables so that the correlation between the two linear combinations is maximized. It derives a number of pairs of linear combinations referred to as canonical variates. The maximum number of canonical variates (functions) that can be extracted equals the number of variables in the smallest data set, independent or dependent. The first function extracted accounts for the maximum amount of variance in the set of variables. Then the second function is computed so that it accounts for as much as possible of the variance not accounted for by the first factor, and so forth, until all factors 
are extracted. Among these, only those canonical correlation are considered important that are statistically significant.

Canonical analysis provides important information about the canonical variates, canonical correlation between the variates and the statistical significance of canonical correlation. Each canonical function consists of a pair of variates, one representing the dependent and the other representing the independent variables. Canonical variates are interpreted on the basis of a set of correlation coefficients called as canonical loading. The larger the coefficient, the more important it is for deriving a canonical variate. To determine which variables are most important in a given pair of canonical variates, canonical weights, canonical loading, and/or canonical cross-loading can be used. Canonical loadings measure the simple linear correlation between an original observed variable in the dependent or independent set and the set's canonical variates. A canonical loading greater than or equal to .30 is considered significant (Christensen, 1983; Hair et al., 1992). 


\section{Research Question 5:}

Are ecotourists' environmental attitude, environmental behavior, travel motivation and value dimension collectively associated with ecotourists' service quality expectations?

\section{Hypothesis 5:}

There is no significant relationship between ecotourists' environmental attitude, environmental behavior, travel motivation and value dimension collectively and ecotourists' service quality expectation of the ecotourists.

To test the above hypothesis canonical correlation analysis was used to investigate the relationship between two sets of variables: independent (environmental attitude, environmental behavior, travel motivation and value dimension) and dependent (ECOSERV).

The results of canonical analysis on the set of seventeen independent factors and six dependent factors are presented in Table 25. The multivariate tests of significance (Wilks lamda, Pillai's criterion, Hotelling's trace, and Roy's greatest root) for the three canonical functions revealed the relationship between the independent composite variate and the dependent composite variate was significant at $p=.0001$ level. According to the test of significance, the null hypothesis 5 was rejected. There were significant 
TABLE 25 RESULTS OF CANONICAL ANALYSIS*

Canonical Correlation Analysis

\begin{tabular}{|l|c|c|c|c|}
\hline Function & $\begin{array}{c}\text { Canonical } \\
\text { Correlation }\end{array}$ & $\begin{array}{c}\text { Canonical } \\
\text { R }\end{array}$ & $\begin{array}{c}\text { F } \\
\text { Statistic }\end{array}$ & Probability \\
\hline & & & & \\
1. & 0.763452 & 0.582859 & 2.9692 & 0.0001 \\
2. & 0.433145 & 0.187614 & 1.5531 & 0.0009 \\
3. & 0.407456 & 0.166020 & 1.4231 & 0.0148 \\
\hline
\end{tabular}

Multivariate Test Statistics

\begin{tabular}{|l|c|c|c|}
\hline Statistics & Value & $\begin{array}{c}\text { Approximate } \\
\text { F }\end{array}$ & Probability \\
\hline Wilks' lambda & 0.20917092 & 2.9692 & 0.0001 \\
Pillai's Criterion & 1.22069767 & 2.5797 & 0.0001 \\
Hotelling's trace & 2.14649590 & 3.4940 & 0.0001 \\
Roy's greatest root & 1.39726809 & 14.1124 & 0.0001 \\
\hline
\end{tabular}

* Dependent Variables: Service quality expectation measures

Independent Variables: Attitude, Behavior, Travel Motivation and Value measures 
Standardized Variance of the Criterion Variables Explained by:

\section{The Predictor Variables}

Function

$$
\text { Proportion }
$$

Cumulative

Proportion
1.
0.3630
0.3630
2.
0.0272
0.3902
3.
0.0160
0.4063
4.
0.0049
0.4112
5.
0.0028
0.4140
6.
0.0040
0.4180

Standardized Variance of the Predictor Variables Explained by:

The Criterion Variables

Function

Proportion

Cumulative

Proportion

1.

0.0411

0.0411

2.

0.0162

0.0572

3.

0.0138

0.0711

4.

0.0059

0.0770

5.

0.0082

0.0852

6.

0.0035

0.0887

* Criterion (Dependent) Variables: Service quality expectation measures

Predictor (Independent) Variables: Attitude, Behavior, Travel motivation and Value dimension 
TABLE 27 CANONICAL ANALYSIS:

\section{SERVICE QUALITY EXPECTATION VS. ATTITUDE, BEHAVIOR, TRAVEL MOTIVATION AND VALUE}

Correlation Between the Criterion Variables and the Canonical Variates of the Predictor Set

Canonical Loadings

Criterion Set: Service Measures

$\mathrm{C} 1 \quad \mathrm{C} 2 \quad \mathrm{C} 3$

1.Tangibility

2. Reliability

.77

3. Assurance

4. Responsiveness

5. Empathy

6. Eco-Tangibility

.82

$\frac{.56}{.52}$

$-$

$-$

Correlation Between the Predictor Variables and the Canonical Variates of the Criterion Set

Predictor Set: Attitude, Behavior, Motivation and Value Measures

Canonical Loadings

1. Fragility of Nature's Balance

P1 $\quad$ P2 $\quad$ P3

2. Rejection of Anthropocentrism

3. Limits to Growth

4. Practice to Recycle

5. Involvement in Environmental Issues

6. Environmentally Friendly Buying Habits

7. Environmentally Friendly Avoidance

8. Friendly Business

9. Concerns for the Environment

10. Intercultural

11. Escape

12. Education

13. Excitement/Thrills

14. Get away

15. Socialization

16. Cost

17. Community Benefits

\begin{tabular}{lcc}
- & -.42 & - \\
.38 & -.43 & .41 \\
.30 & -.51 & .44 \\
- & -.26 & - \\
- & -.40 & - \\
- & -.42 & - \\
- & - & - \\
- & - & -.30 \\
- & -.39 & .30 \\
- & -.47 & -.52 \\
- & - & - \\
- & - & .31 \\
- & - & - \\
- & - & -.33 \\
- & - & -.50 \\
.33 & - & - \\
.91 & & - \\
\hline
\end{tabular}

$\mathrm{C} 1=$ Criterion variate of the first function $\quad \mathrm{P} 1=$ Predictor variate of the first function 
relationships found between the independent variables and dependent variables.

In this analysis there were three interpretable canonical functions whose canonical correlation was significantly different than zero at the probability level of .0001 as per the F statistics based on Rao's approximation. The canonical correlation ranged from .76 to .41 . The overlapping variances between pairs of canonical variates, which are equal to the squared canonical correlation for each function, ranged between $58 \%$ and $17 \%$. The redundancy index for canonical functions indicated that $42 \%$ of the variance in the dependent variables was accounted for by the variability in the independent variables. Conversely, only $9 \%$ of the variation in independent variables was accounted by the dependent variables (Table 26). This implies that attitude, behavior, travel motivation and value dimension measures influence the service quality expectation measures. To describe the relationship between the independent and dependent (service quality expectation) measures, canonical loading greater than absolute value of + or -.30 were considered for interpretation of the variate in Table 27.

An examination of the canonical loadings for the first variate (function) indicated that the composite score for the environmental attitude and value dimension factors was significantly related to service quality expectation 
factors. In other words ecotourists who perceive ecotourist business to Educate and Benefit the Community (.91), Reject the Anthropocentric View of Nature (.38), and belief in Limits to Growth (.30), tend to expect Assurance (.91) and Eco-Tangibles (.82) services more than other services.

Educate/Benefits to the Community refers to ecotourist business using part of its profits to educate locals/guests about environmental issues and helping in community projects. Assurance refers to knowledge and courtesy of employees and their ability to convey trust and confidence to customers. EcoTangibles refer to facilities that are appropriate to the environment, equipment that minimizes environmental degradation and facilities that are environmentally safe.

The second variate pair (function) revealed that composite score for environmental attitude, environmental behavior and travel motivation items was significantly related to three service quality expectation factors. Interpretation of canonical loadings showed negative reasons to travel [Intercultural Motivation (-.47)], negative attitude toward the environment [Limits to Growth (-.51), Rejection of Anthropocentrism (-.43), and Fragility of Nature's Balance (-.42)], and negative environmental behavior patterns [Involvement in Environmental Issues (-.40), Concern for the Environment (-.39)]. It can be concluded that if reasons to travel are not Intercultural, if attitude toward the 
environment is anthropocentric, if there is no involvement in the environmental issues and if there is no concern for the environment, service expectations from an ecotourist business tend toward Responsiveness (.56) and Empathy (.52) and not Eco-Tangibles (.02).

Intercultural motivation refers to learning about other cultures; meeting people from different cultures; visiting historical and cultural sites/monuments; trying new foods; learning about host customs; and participating in local entertainment. Responsiveness refers to willingness to help customers and provide prompt service. Empathy refers to caring, individualized attention the firm provides its customers. Eco-Tangibles refer to facilities that are appropriate to the environment, equipment that minimizes environmental degradation and facilities that are environmentally safe.

The composite score of the third variate pair (function) revealed that selected environmental attitude, environmental behavior and travel motivation factors are significantly related to selected service quality expectations factors. Interpretation of canonical loadings showed negative reasons to travel [Intercultural Motivation (-.52), Socialization (-.50), Get Away (.33)], negative environmental behavior [Friendly Business (-.30)], positive attitude toward environment [Limits to Growth (.44), Rejection of Anthropocentrism (.41)], positive reasons to travel[Education (.31)] and positive 
environmental behavior [Concerns for the Environment (.30)]. In other words when more importance is given to the natural environment and not much to cultural interaction, the services expectations of the ecotourists tend to be more toward Eco-Tangibles (.45) and not Tangibles (.-50).

Intercultural motivation refers to learning about other cultures; meeting people from different cultures; visiting historical and cultural sites/monuments; trying new foods; learning about host customs; and participating in local entertainment. Get Away motivation refers to being by oneself, to rediscover oneself. Friendly Business refers to businesses as being more environmentally friendlier than ten years back. Education motivation refers to traveling to learn more about environment and to experience unpolluted settings. Concerns for the Environment refers to behaviors that give priority to environmental issues. Eco-Tangibles refer to facilities that are appropriate to the environment, equipment that minimizes environmental degradation and facilities that are environmentally safe. Tangibles refer to materials (such as pamphlets or statements) and facilities that are not only visually appealing but reflect local influence; employees that are in local comfortable attire; facilities that provide local entertainment and are in unpolluted setting. 


\section{Research Question 6:}

Are ecotourists' travel characteristics associated with ecotourists' perceived service quality expectations?

\section{Hypothesis 6:}

There is no significant difference between travel characteristics and service quality expectations of the ecotourists.

To test the above research hypothesis delineated ECOSERV factors were used. One-way analysis of variance was performed to examine the differences in the mean values of the dependent variable (ECOSERV factors) associated with the independent variables (selected travel characteristics). The ECOSERV factors were: Empathy, Eco-Tangibles, Tangibles, Reliability, Assurance and Responsiveness. Selected travel characteristics were: travel group, number of nights stayed, lodging type and trip planning (how far in advance the trip was planned). T-tests were done to investigate if the six service factors would remain stable or differ between ecotourists whose trip was overseas and those which were not overseas.

A total of 24 one-way analyses of variance were performed and three significant findings were found (Table 28 and Table 29). The findings showed that there was no significant difference between selected travel characteristics (Travel Group and Number of Nights) and six service quality expectation 
iators (Table 28). On the other hind, were was a significant difference between

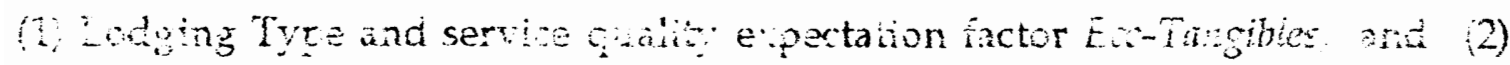

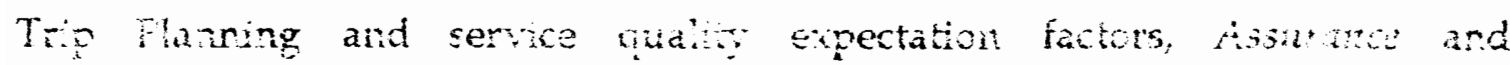

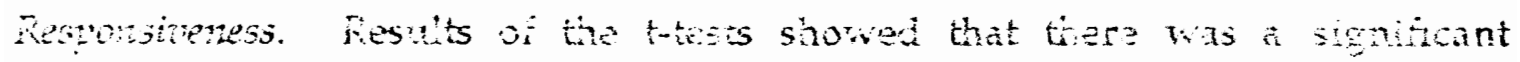
diferane betwesn Overseds vapobles for servica quatin expectaton inctors

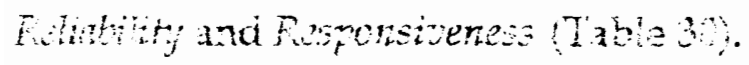

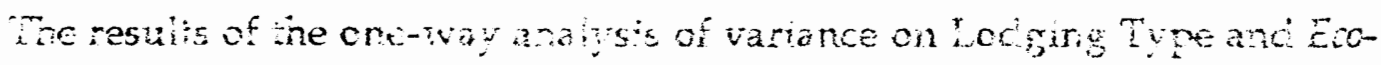
T.t.gitit are zresented ir Table 29. These findings showed for the null Wyothesis no significant ditfereace betiven Ludging brpe and Ech-Tangibles whic wis rejected because the F nive was 2.33 with an ascociated probabilty of in. The Duncar's Multiple Pangs Test indicated that the service cadity expetation of Ex-Iangibles for the lodging group that stayed with fHends/riatives $(\hat{x}=5.0)$ was significantly lower than loding group that stayed in cabirs $(\bar{x}=6.13$, thets $(6,4)$, hotel/ncte! $(\bar{x}=6.4)$ and huts $(x=6.8)$. In Qher words ecotourists expect ecotourist businesses that provide calins, tents, Folel/motel and huts to be irore envirormentally safe and friendly to avcid environnenta! degradation.

One-way anaiysis of variance pertormed on Trip Panning and Asiarance statistics are presented in Tabie 29. There was a significant cifference found between Trip Flaning ard Assurance service factor with a F-valie of 2.46 and 




Table 28 ONE-WAY ANALYSIS OF VARIANCE

SERVICE QUALITY EXPECTATION FACTORS BY TRAVEL GROUP AND NUMBER OF NIGHTS

\begin{tabular}{lcccccc}
\hline Variables & Emp. & $\begin{array}{c}\text { Eco- } \\
\text { Tang. }\end{array}$ & Tang. & Reliab. & Assur. & Resp. \\
\hline Travel Group & & & & & & \\
$\quad$ Alone & .0737 & .0581 & -.0711 & .1380 & .0216 & -.0622 \\
Friends & .0138 & -.0747 & .2141 & .1966 & -.2071 & .1687 \\
Family & .0144 & -.0347 & -.0110 & -.0691 & .1137 & .1003 \\
Organized & -.0399 & .0977 & -.0100 & -.0829 & .0092 & -.1486 \\
Other & -.0578 & -.4652 & -.4843 & .0142 & .0904 & .0269 \\
F-value & .0972 & 1.0382 & 1.5796 & .9385 & .9342 & 1.2115 \\
Sig-level & .9833 & .3881 & .1804 & .4422 & .4447 & .3065 \\
& & & & & & \\
\# of Nights & & & & & & \\
1 wk & .0872 & -.1090 & -.0736 & .0845 & -.1107 & -.1504 \\
2 wks & -.0532 & .0439 & -.0233 & -.0398 & .0417 & .0563 \\
3 wks & .0993 & -.1016 & .2320 & -.0747 & .0035 & .0381 \\
or more & -.0078 & .1208 & -.2002 & .2387 & .0007 & -.1005 \\
F-value & .4556 & .5807 & 1.6007 & .8135 & .3167 & .7362 \\
Sig-level & .7136 & .6282 & .1898 & .4875 & .8133 & .5313 \\
\hline
\end{tabular}

Emp. (Empathy); Eco-Tang. (Eco-Tangibles); Tang. (Tangibles);

Reliab. (Reliability); Assur. (Assurance); Resp. (Responsibility)

Note: Superscripts $(a, b)$ different from each other at the .05 level or better probability level. 
Table 29 ONE-WAY ANALYSIS OF VARIANCE

\section{SERVICE QUALITY EXPECTATION FACTORS BY LODGING TYPE AND TRIP PLANNING}

\begin{tabular}{|c|c|c|c|c|c|c|}
\hline Variables & Emp. & $\begin{array}{l}\text { Eco- } \\
\text { Tang. }\end{array}$ & Tang. & Reliab. & Assur. & Resp. \\
\hline \multicolumn{7}{|l|}{ Lodging } \\
\hline \multicolumn{7}{|l|}{ Type } \\
\hline$\overline{\text { Hotel} / \text { Motel }}$ & -.0893 & $.0242^{b}$ & .1440 & .1062 & .0600 & .0351 \\
\hline $\mathrm{BB}$ & -.0365 & .1043 & .0988 & -.4208 & .1804 & .0154 \\
\hline Huts & -.9044 & $.4549^{b}$ & .2176 & .0335 & .3983 & .1023 \\
\hline Friends/Rel & .1224 & $-\overline{1.4953}{ }^{a}$ & .3721 & -.1106 & -.5293 & -.0452 \\
\hline Camps & .0240 & .1616 & .1864 & -.5931 & -.2793 & -.5086 \\
\hline Tents & -.0012 & $.0158^{b}$ & -.0043 & -.1640 & -.0618 & .0419 \\
\hline Cabins & .1180 & $-.0635^{b}$ & -.1202 & .0084 & .0840 & .1542 \\
\hline Ranch & .1020 & -.1068 & .6942 & .3038 & -.0481 & -.0169 \\
\hline Other & .1525 & $.1834^{b}$ & -.3006 & .1308 & -.1773 & -.3127 \\
\hline F-value & 1.2380 & $\overline{2.3293}$ & 1.4786 & 1.0556 & .8195 & 1.1768 \\
\hline Sig. level & .2775 & $.0200^{*}$ & .1656 & .3952 & .5861 & .3137 \\
\hline \multicolumn{7}{|l|}{ Trip } \\
\hline \multicolumn{7}{|l|}{$\overline{\text { Planning }}$} \\
\hline Less $2 \mathrm{w} k s$ & -.0917 & -.5578 & -.0795 & -1.1515 & 2.1174 & -.0823 \\
\hline 3-4 wks & .0194 & .2018 & .2837 & -.0788 & -.0629 & .3971 \\
\hline 1-3 mths & -.1026 & -.0911 & -.0406 & -.1313 & $-.0246^{a}$ & $-.1752^{a}$ \\
\hline 3-4 mths & .1575 & -.0720 & -.0070 & .0016 & -.0913 & $\overline{-.1968}$ \\
\hline 5-6 mths & .0371 & .1384 & -.1204 & -.0068 & -.0973 & -.0788 \\
\hline 6 mths + & -.0218 & -.0062 & .0636 & .0995 & $.0601^{b}$ & $.1936^{b}$ \\
\hline F-value & .3525 & .5383 & 4872 & 1.1367 & $\overline{2.4619}$ & $\overline{2.1027}$ \\
\hline Sig.level & .8803 & .7472 & .7856 & .3415 & $.0337^{*}$ & .0658 \\
\hline
\end{tabular}

Emp. (Empathy); Eco-Tang. (Eco-Tangibles); Tang. (Tangibles);

Reliab. (Reliability); Assur. (Assurance); Resp. (Responsibility)

Note: Superscripts $(a, b)$ different from each other at the .05 level or better probability level 
Table 30 T-TEST ANALYSIS: SUMMARY

SERVICE QUALITY EXPECTATION AND OVERSEAS TRIP

\begin{tabular}{lcccccc}
\hline Variables & Emp. & $\begin{array}{c}\text { Eco- } \\
\text { Tang. }\end{array}$ & Tang. & Reliab. & Assur. & Resp. \\
\hline $\begin{array}{l}\text { Overseas } \\
\text { Trip }\end{array}$ & & & & & & \\
$\quad$ Yes & -.0748 & -.0103 & .0795 & -.1110 & -.0404 & -.1250 \\
$\quad$ No & .1022 & .0288 & -.0924 & .1249 & .0592 & .1442 \\
& & & & & & \\
t-value & -1.47 & -.32 & 1.51 & -1.99 & -.83 & -2.35 \\
Sig. level & .142 & .75 & .133 & $\underline{.048^{*}}$ & .405 & $\underline{.019^{*}}$ \\
\hline
\end{tabular}

Emp. (Empathy); Eco-Tang. (Eco-Tangibles); Tang. (Tangibles);

Reliab. (Reliability); Assur. (Assurance); Resp. (Responsibility)

(*) denotes significance at the 0.05 levels 
probability level of .03 . Therefore the null hypothesis that there is no significant difference between Trip Planning and Assurance was rejected. The Duncan's Multiple Range Test reveals that the perceived service quality expectation of Assurance for trip planning group which took one to three months $(\bar{x}=4.0)$ to plan the trip was significantly lower than trip planning group which took over six months $(\hat{x}=4.3)$ to plan the trip. It is evident that ecotourists who planned trips well in advance (six months or more) were expecting more Assurance. Assurance refers to customers feeling safe in their transaction with ecotourist business; ecotourist businesses that provide necessary information; employees that have adequate knowledge to answer questions; and employees that are consistently courteous to customers.

The statistics showing one-way analysis of variance on Trip Planning and Responsiveness are presented in Table 29. The results showed that the null hypothesis that there is no significant difference between Trip Planning and Responsiveness was rejected because there was a mildly significant difference between trip planning and responsiveness with a F-value of 2.10. The Duncan's Multiple Range Test suggest that the service quality expectation of Responsiveness for the trip planning group which took one to three months $(\bar{x}=$ 2.9) to plan the trip was significantly lower than trip planning group which took over six months $(\bar{x}=3.3)$ to plan the trip. 
T-tests results of overseas variables and six service factors are shown in Table 30. It is evident that there was a significant difference between ecotourists whose trips were overseas and those whose trips were not overseas. It can be interpreted that ecotourists whose trips were not overseas tend to prefer service quality factors Reliability and Responsiveness. 


\section{SUMMARY}

This chapter presented and discussed the study's results. Statistical relationships between independent variables (environmental attitude, environmental behavior, travel motivation and value dimension) and dependent variable (service quality expectation) were examined using Pearson's correlation coefficient and canonical correlation analyses. Selected travel characteristics variables were evaluated using one-way analysis of variance followed by Duncan's multiple range tests if there was any significance and by utilizing t-tests.

Correlation coefficient analysis showed several significant relations between independent and dependent variables at modest to moderate levels. The canonical correlation analysis revealed that the measures of environmental attitude, environmental behavior, travel motivation and value dimension were associated significantly with ECOSERV (service quality expectation) measures, resulting in three interpretable canonical variates (functions). Oneway analysis of variance revealed three significant travel characteristic variations among ECOSERV factors. Furthermore, Duncan's multiple range test showed the groupings and made it possible to identify the service expectation factors. Discussion and implications of this study's findings are discussed in the next chapter. 


\section{CHAPTER FIVE \\ SUMMARY AND CONCLUSION}

\section{INTRODUCTION}

Earlier chapters defined the justification of the study, a conceptual model, research hypotheses, methodology and statistical results. This chapter discusses the findings of the study, contribution of the study, limitations of the study and recommendation for future research.

\section{FINDINGS OF THE STUDY}

This study was undertaken to examine the relationship between environmental attitude, environmental behavior, travel motivation, value dimension and service quality expectations of ecotourists. First, frequency distribution was used to profile the demographic and travel characteristics of the ecotourists. Second, the Pearson's correlation coefficient analysis was used to test the first four hypotheses, and canonical correlation analysis to test the fifth hypothesis. These correlation analyses were done to generate an insight into the correlation and co-variation of the dependent variable and the independent variables. Hypothesis six was tested using one-way analysis of variance and t-test for selected travel characteristics and service quality expectation factors of the ecotourists. 
This section presents the profile of the ecotourists based on the frequency distribution of the demographic and travel characteristics variables; results of the research hypotheses; a discussion of the significant findings of the six hypotheses; and implications of the research findings.

\section{Profile of Ecotourists based on Demographic and Travel Characteristics}

Demographic characteristics of the ecotourists revealed that majority of the respondents were between $45-54$ years old, followed by 35-45 years, 55-64 years, 65-74 years, and 25-34 years. The distribution of the age variable appears to be an older group with $77 \%$ of the respondents between 35 to 64 years old. Both males and females were interested in ecotourism experience. Education levels were higher with majority having attended graduate school and had income levels between $\$ 50,000$ to over $\$ 100,000$. There seems to be a correlation between education and income variables, higher education relates to higher income group. In other words, it appears that most of the ecotourists are older, with higher educational level and earning higher income.

Majority of the respondents in this study were married. A good percent of the households were single living alone also. Retired households with atleast one retired spouse was a relatively significant group in this study. The majority of the respondents lived in cities and suburbs compared to rural areas, and were employed as professionals. A vast majority identified themselves as 
white and lived in California, followed by New York, Florida, Illinois and Michigan.

A closer examination of travel characteristics revealed majority of the trips taken by the ecotourists were overseas, outside the United States and traveled with an organized group or family group. Most of the ecotourists used airlines and their trips lasted for mostly two weeks. Cabins and tents combined were the most preferred accommodation, hotel/motel was also preferred by many. Expenditure per capita per visit revealed three groups, one which spent under $\$ 2000$, second between $\$ 2,100$ to $\$ 5000$, and third over $\$ 5000$. The majority spent between $\$ 2,100$ to $\$ 5,000$, and the average expenditure was $\$ 3,700$. It can be concluded that American ecotourists would spend an average of around $\$ 3,700$ for an ecotourism experience. The trip planning period consisted of more than six months for the majority of the ecotourists. Most of the findings of this study expands and confirms with earlier findings reported by Boo (1990), Ryel and Grasse (1991), and Wight (1996).

The distribution of demographic and travel characteristic variables suggest that ecotourists appear to be older, with higher education levels and higher income levels. This group of the traveling public seems to have more leisure time and disposable income to stay for an average of two weeks and spent on an average $\$ 3,700$ per trip. Also, it seems that this group not only was 
willing to spent more time and more money, but took more that six months to plan the whole trip. In other words, these are serious travelers who know what they are looking for and their trips are not planned on spur of the moment.

\section{Research Hypotheses}

Hypothesis 1: There is no significant relationship between environmental attitude and service quality expectations of the ecotourists.

The results of correlation analysis showed that there were some significant relationships found between selected environment attitude factors and selected service quality expectation factors, thus revealing partial support for the hypothesis with moderate coefficient levels.

Hypothesis 2: There is no significant relationship between environmental

behavior and service quality expectations of the ecotourists.

An examination of the correlation analysis between service quality expectation factors and environmental behavior factors, indicated that there were nine significant correlations. There was partial support for hypothesis 2 , 
and it was rejected for the nine correlations, though the coefficient levels varied from fairly modest to moderate.

Hypothesis 3: There is no significant relationship between travel motivations and service quality expectations of the ecotourists.

The results of the correlation analysis performed on the set of six travel motivation factors and six service quality expectation factors revealed six significant relationships with modest to moderate correlation coefficients. Partial support for the hypothesis was obtained.

Hypothesis 4: There is no significant relationship between value dimension and service quality expectations of the ecotourists.

The findings of correlation analysis revealed that all factors of service expectations were significantly related to value factors. Therefore, hypothesis 4 was rejected. 
Hypothesis 5: There is no significant relationship between ecotourists' environmental attitude, environmental behavior, travel motivation and value dimension collectively, and service quality expectations of the ecotourists.

Canonical correlation analysis was used on the set of seventeen independent factors and six dependent factors. The multivariate tests of significance (Wilks lamda, Pillai's criterion, Hotelling's trace, and Roy's greatest root) for the three canonical functions demonstrated a significant relationship between the independent composite variate and the dependent composite variate at $\mathrm{p}=.0001$ level. According to the test of significance, null hypothesis 5 was rejected. The redundancy index for canonical functions indicated that $42 \%$ of the variance in the dependent variables was accounted for by the variability in the independent variables. Conversely, only $9 \%$ of the variation in independent variables was accounted by the dependent variables

Hypothesis 6: $\quad$ There is no significant difference between travel characteristics and service quality expectations of the ecotourists.

Hypothesis six was tested using one-way analysis of variance, Duncun's multiple range test and t-test for selected travel characteristics and service 
quality expectations of the ecotourists. The findings revealed that lodging type, trip planning and overseas trip had significant effects on selected service quality expectations of the ecotourists.

\section{Significant Findings of the Six Hypotheses:}

The correlational analyses of the first four hypothesis showed that most of the factors of service quality expectation and corresponding factors (environmental attitude, environmental behavior, travel motivation and value) that were significantly related were both influenced by environmental issues/ concerns, or socio-cultural factors. The relationship exhibited was in a positive direction at moderate to modest levels.

The three attitude factors (indicating an agreement with the ecological worldview) were related to eco-tangible service factor (environmentally appropriate facilities and equipment). Interestingly the same service factor (eco-tangibles) was related more to the behavior factors that represented environmental concerns. An examination of travel motivation and service factors showed educational travel motivations (knowing more about nature) were correlated to eco-tangibles. Also, socialization and intercultural travel motivation factors were found to be significantly related, at a moderate level, with tangible service factor groupings. Tangibles refer to facilities and materials that reflect local cultural influence. 
The correlation between value and service factors revealed all factors to be significantly related. Upon closer examination of the coefficients revealed, educate and benefits to the community factor were more related to service factors than cost of the service factors. Among the service factors, assurance was found to be strongly related to educate and benefit factors. In general, the results of the correlation analysis showed an expected pattern of the relationships between environmental attitude, behavior, travel motivation and value factors, and corresponding service quality expectation factors.

These relationships exhibited positive but moderate to modest strength with emphasis on environmental and socio-cultural issues. For an exploratory study of this kind, the direction of this relationship may reveal more than the strength of the relationship. The direction of the relationships supports the notion that positive attitude and behavior toward the environment most likely prefer services that are environmentally positive or friendly. Also, it indicates that when reasons to travel are intercultural and social, the services most likely to be expected are eco-tangibles, which refers to material and employees reflecting local cultural influence.

The results of canonical correlation analysis to test the fifth hypothesis demonstrated that service quality expectations of the ecotourists were influenced by their attitude toward the environment, behavior patterns, 
reasons to travel and their emphasis on value. Three interpretable canonical functions (variates) were generated. The interpretation of canonical functions explained the importance of six service quality expectation factors in relation to environmental attitude, environmental behavior, travel motivation and value dimension factors.

The first variate pair (function) revealed that ecotourists (who perceive ecotourist business to help and benefit the community and to use part of its profits to promote environmental awareness; whose beliefs and feelings relating to environment are ecocentric; who thinks that there is a limit to growth on this earth) tend to prefer most those services that convey trust and confidence; employees that are knowledgeable and courteous; and facilities and equipment that are friendly to the environment. It can be interpreted that ecotourists' who have an ecocentric attitude toward the environment, tend to expect services that are courteous, informative, trustworthy, in addition to environmentally friendly facilities and equipment. Because of ecotourists' sensitivity toward environmental issues, they prefer services that minimize the negative impact on the environment.

The second variate pair (function) demonstrated that when travel is not for intercultural interaction; when the attitude toward the environment is not ecocentric; when there is no involvement in environmental issues; and when 
there is no concern for the environment; the services expected by the ecotourists might be responsiveness and empathy. In other words when the attitude and behavior toward the environment is not friendly and intercultural interactions are not important, services are expected to be performed on promised time; with personal and individual attention; and promptness. Also, it was evident that negative attitude and behavior toward the environment tend to care less for environmentally friendly facilities and equipment.

The third variate pair (function) revealed that when there is no interest in intercultural social interactions; more interest in learning about the environment; when one feels that businesses are not environmentally friendly now than ten years back; there is an ecocentric attitude toward the environment; the service preference tend to be eco-tangibles. Eco-tangibles refer to ecotourist business having facilities that are appropriate to the environment, facilities that are environmentally safe and equipment that minimize environmental degradation. It indicated that when more importance is given to environmental issues than to intercultural social interactions, service expectations are not inclined toward reliability, assurance, empathy or responsiveness but towards eco-tangibles. In other words, positive attitude toward the environment tend to prefer services that are environmentally friendly with minimum strain on the ecosystem. This concurred with earlier reporting that ecotourists do not require luxurious accommodation or services 
but prefer conditions and settings to be locally appropriate. Ecotourists may be are less demanding and prefer to experience a more simpler lifestyle (Boo 1990; Eagles 1992).

An interpretation of Hypothesis 6 suggests that ecotourists when staying at hotels/motels, cabins, tents and huts prefers businesses to be more environmentally conscious as compared to staying with family/friends. Also, ecotourists who plan their trip well in advance (over six months) expect more assurance and responsiveness from the ecotourist business than ecotourists who plan their trip one to three months in advance. It can be further stated that ecotourists expect reliability and responsiveness more from businesses in the United States compared to businesses overseas.

\section{Implication of the Research Findings}

The results of this study are encouraging in that the demographic profile of the ecotourists tend to support and expand on the findings reported in previous studies. The demographic and travel characteristic profiles presented in this study can also help ecotourism destination marketers in planning strategies. The findings suggest that ecotourists are highly educated, with high income levels, either male or female, married, professionals and living in big cities or suburbs. They mostly travel by airlines, with an organized or family groups, stay at hotels or cabins, for an average stay of two weeks, spend around 
$\$ 3,700$ and take over six months to plan their trips. This information can help the ecotourist marketers to plan effective communication strategies.

The global growth and potential of ecotourism have created an opportunity for ecotourist businesses to develop high quality services to stay competitive in the market place. The findings revealed that a positive attitude toward the environment is related to service quality dimensions of assurance and eco-tangibles more than other service dimensions. This implies that ecotourist businesses that may wish to attract environmentally sensitive travelers might see that the facilities they have are appropriate and safe to the environment and equipment that minimize environmental degradation. For example, in the rain forest, ecotourists may not be expecting services and facilities of a five star hotel, but rather a cabin or a hut made from local materials, using local knowledge that is appropriate to the environment with minimum impact on the environment.

The findings also revealed that a positive attitude toward the environment is related to the assurance service expectation. Assurance refers to courtesy and knowledge of the employees, and their ability to convey a feeling of trust and confidence by providing necessary information. This implies that ecotourist business in order to satisfy environmentally conscious travelers might provide services that are courteous, informative, and that convey a 
feeling of trust. For example, information relating to vaccinations, type of clothing, or travel in the night if the activity involves rain forest journey. In some ecotourist destinations there are no air conditioners or hot water available, so the ecotourists should be informed of these things in advance. Effective marketing efforts to meet the service expectations of the environmentally positive tourists would include an ecotourist business that adopts policies and procedures that cause minimum impact on the environment. A business where the three $R^{\prime}$ s (recycling, reusing and reducing) are followed. A business that trains the contact personnel, who are well aware of local environment and who are willing to instill a feeling of trust and confidence. A business where standards are set on the basis of customer expectations, and contact personnel are encouraged to perform in accordance to those standards.

The Interpretation of the second variate indicated that when the attitude and behavior toward the environment is negative, and when the motivation to travel is not to seek environmental knowledge, services like responsiveness and empathy can be emphasized. The expectations from the contact personnel at such businesses would be to provide prompt, personnel and individualized service. Quality improvement efforts can be directed toward contact personnel in order to increase their willingness and ability to perform. Training sessions to continuously develop their performance and competence can be encouraged. 
It was also apparent from the interpretation of the third variate pair, that when the attitude toward the environment is positive, and when there in no interest in intercultural social interactions, the service preference tend to be eco-tangibles and not tangibles. The services desired here would be facilities and equipment that are environmentally appropriate and safe. The marketing efforts would include an experience in unpolluted environment with simple facilities as opposed to high tech facilities that require a constant drain on natural resources. A hut or a cabin in the forest, with open ventilation, fresh water, neat and simple setting, and close encounter with nature is probably what is desired.

Knowledge of ecotourists' service quality expectations in relation to their attitude, behavior, travel motivation and value dimensions provided an insight into what services will satisfy the needs and expectations of the ecotourists. It can be concluded that ecotourists with a positive attitude toward the environment, tend to prefer ecotourist businesses to have facilities and equipment that are environmentally friendly. The contact personnel are expected to be trained, in order to have adequate knowledge to instill a sense of trust and confidence. Understanding customer expectations is a prerequisite for delivering superior service (Parasuraman et al. 1985). This information about ecotourists' service expectations would be valuable in determining how an ecotourism marketer should position or reposition in the market place. 
Promotional themes could connect an ecotourist business service with needs and expectations relevant to specific target markets. Businesses that are involved in helping local communities, promoting recycling of resources, minimizing the energy usage, educating hosts/guests etc., can use it to their advantage. Their marketing efforts can include conservation and preservation theme to attract the specific market. The ecotourist managers should ensure that the benefits offered to the customers in promotional activities should be delivered as promised. And once a desired service quality is achieved to satisfy the customers, efforts should be made to maintain it over repeated service encounters. Since satisfaction over time results in perceptions of service quality (Parasuraman et al., 1988).

\section{CONTRIBUTION OF THE STUDY}

The potential contribution of this research study can be found in theoretical, methodological and marketing/practical implication:

1. Theoretical Implication: This study contributes to the existing ecotourism and service marketing literature. It provides an insight into the environmental attitude, environmental behavior, travel motivation and travel characteristics of the ecotourists. It also presents an analysis of the relationship between behaviors and service quality expectations of the ecotourists by proposing a conceptual model. The scales used and developed to measure the 
environmental attitude, environmental behavior, travel motivation, value dimension and service quality expectations of the ecotourists adds to the limited literature on ecotourism and service quality in both hospitality and tourism areas. The new and revised NEP scale (Dunlap et al., 1991) demonstrated that it can be used to measure the changing attitude of American society, in its shift toward the natural environment. The behavior scale used in this study appears to be a helpful tool to measure the environmental behavior patterns of the ecotourists based on their practices to recycle, involvement in environmental issues, concerns for the environment and friendly buying habits. The travel motivation scale based on Mannell and Iso-Ahola's (1987) escape and seek dimensions, also appears to be a valid tool to measure as to why ecotourists travel. However, further research studies using these scales are needed to validate the scales.

A major contribution of this study is the scale to measure the service quality expectations of the ecotourists called ECOSERVE, an adapted version of SERVQUAL (Parasuraman et al., 1986, 1988, and 1991). It consisted of 30 items based on six service dimensions as compared to 22 items based on five service dimensions of SERVQUAL. In this study the tangible factor split into two subdimensions, one pertaining to facilities and equipment, and the other to employees and communication materials. This splitting of the tangible factor is consistent with the findings of earlier study, where the SERVQUAL scale was 
modified (Parasuraman et al., 1991). The six service dimensions of the ECOSERV scale and their definitions in this study are as follows: Tangibles, Eco-Tangibles, Assurance, Responsiveness, Reliability and Empathy:

Tangibles: material and appearance of the personnel that reflects local influence

Eco-tangibles: physical facilities and equipment that are safe and appropriate to the environment

Reliability: Ability to perform the promised service dependably and accurately

Responsiveness: willingness to help customers and provide prompt service Assurance: $\quad$ knowledge and courtesy of the employees and their ability to convey trust and confidence, and provide necessary information

Empathy: Caring, individualized attention the firm provides its customers

2. Methodological Implications: Since there was not much data base to use or apply, the whole process of collecting the data for the study created a unique challenge. To begin with, tour operators who specialize in the area of ecotourism were contacted to generate a mailing list of ecotourists. With not much published literature relating to the ecotourist market, other studies in the general marketing, hospitality and tourism areas that were appropriate were used. Also, information provided by a nominal group technique approach was included in environmental behavior, travel motivation, value and service quality expectation scales. 
The relationship between multiple independent and multiple dependent variables was presented in a conceptual model. The relationship between the two sets of variables was studied through the use of Pearson's correlation coefficient analysis and canonical correlation analysis. The use of canonical correlation analysis demonstrated that it is a useful technique to study the relationships between multiple dependent variables and multiple independent variables. The findings revealed by the three significant canonical variates (functions) can be used by decision makers to package products and services to better satisfy the ecotourist market.

3. Marketing and Practical Implications: As ecotourism continues to grow, it appears to be a viable market for destinations to foster sustainable economic development. This study presented the profile of the ecotourists based on the frequency distribution of demographic and travel characteristic variables. The main objective of this study, however, was to test the six hypotheses which identified the service quality expectations of the ecotourists in relation to their environmental attitude, behavior, travel motivation, value dimension and selected travel characteristics. It explained as to what dimension of service quality is expected by the ecotourists when they visit an ecotourist business. The key to providing superior service is understanding and responding to customer's expectations (Parasuraman et al., 1991). Therefore, in order for the ecotourism industry to respond to the needs of the ecotourists, an 
understanding of their service quality expectations is important. The findings reported in this study can be used by ecotourism marketers, tour operators and destination planners/promoters to devise marketing and development programs to attract this growing market segment.

A knowledge of ecotourists' demographic and travel characteristic profile can be used by ecotourism marketers and tour operators to design appropriate marketing strategies. The findings suggest that this group not only is willing to spent more time and more money, but takes more that six months to plan the whole trip. These trips were not planned on spur of the moment, but rather were planned carefully. The ecotourists' marketers/operators can utilize such information when targeting this market segment. For example, material for a summer eco-trips can be sent six to eight months in advance, with reminders after couple of months.

The findings also supports the notion that this group of ecotourists belonged to higher age, education and income levels, therefore the promotional material can be designed accordingly to reach this elusive market segment. The distribution of demographic variables suggests, that this group appeared to be older, with more leisure time and disposable income, willing to spend $\$ 3,700$ per trip for an average stay of two weeks. This information 
can be useful to the marketers in designing trip packages, and establishing different price strategies.

The findings of this study can be helpful to the ecotourist destination promoter/planner for future development initiatives. For example, an important finding of this study indicated that ecotourists who perceive ecotourist businesses to educate and help the community and had a positive attitude toward environment, tend to prefer assurance and eco-tangible services more than other services. In other words, in order to fulfill such service expectations, the ecotourists' businesses not only should have facilities and equipment that are environmentally safe, but also provide contact personnel who convey a sense of trust and confidence. The ecotourist business that wishes to attract environmentally sensitive travelers, must provide facilities that are simple but comfortable that causes minimum strain on the environment. There are many ecotourist lodging facilities that use local indigenous materials, know-how, and practices to achieve this goal. This not only keep the costs down but also make the maintenance easier. In order to convey a feeling of trust and confidence, such measures when applied at an ecotourist business should be made known to the interested party. Also, the tour operators can include themes in their communication materials that reflect an environmentally positive experience. 
In this study, ecotourists placed less emphasis on reliability, responsiveness and empathy, and more emphasis on assurance, eco-tangible and tangibles service dimensions. Marketing communications should focus on presenting ecotourist businesses to be environmentally friendly, reflecting local cultural influence and having contact personnel who convey a feeling of trust and confidence. Product development might highlight facilities and equipment to be environmentally safe and appropriate with minimum strain on the natural resources.

\section{LIMITATIONS OF THE STUDY}

In designing the study, efforts were made to minimize its limitations. One of the limitations of the study was that there is not yet a consistently used definition of ecotourism, because of the many stakeholders involved in it (Wight, 1993a). It is called as nature tourism, soft tourism, alternative tourism, cultural tourism, adventure tourism or green tourism. The population used for this study were considered ecotourists, since the mailing list was provided by tour operators who specialize in ecotourism. Therefore, it is assumed that the one's who responded to the study are all ecotourists. The findings of the study can be generalized to ecotourists living in the United States of America.

In this study the expectation items of service quality measures were used. The perception measures were not included, since it was not possible to 
have the respondents complete an expectation questionnaire before going on a trip, and complete the perception questionnaire after coming back from the trip. With a mail survey that used a national sample it was not possible. According to Carman (1990), both expectation and perception measures cannot be administered at the same time.

Finally, the independent variables used in the study were environmental attitude, environmental behavior, travel motivation, value dimension and travel characteristics. There might be other variables not used in this study that can influence the service quality expectations of the ecotourists. For example, destination attributes, the pull factors of a destination were not used. It would be an important attribute to study, since travelers are deemed to place a great deal of importance on benefits they derive from an activity or product (Gitelson and Kersteller, 1990).

\section{RECOMMENDATION FOR FUTURE RESEARCH}

The serious lack of research with regard to the ecotourist market and the service quality expectations of the ecotourists formed the basis for this study. The research study revealed several significant findings regarding ecotourists. Canonical correlation revealed the service quality expectations of the ecotourists in relation to their environmental attitude, environmental behavior, travel motivation, and value dimension. A similar study with a 
comparison between ecotourists and mass tourists on the basis of service quality expectations is recommended.

Second, this study used canonical correlation analysis to examine the relationship between independent and dependent variables and identify commonalties between the two. A factor - cluster segmentation based on service expectations of the ecotourists can be used to delineate existing possible sub-segments of this market.

Third, service quality expectation of the ecotourists can be studied using other independent variables such as image measures, knowledge attributes, destination factors, activity preferences, etc. With emphasis on service quality as an important criterion for businesses to position themselves in the global market place, such information will be very helpful.

Fourth, this study used the expectation dimension of the original SERVQUAL scale, a similar study with both expectation and perception dimensions based on the gap theory (Parasuraman et al. 1986) for an individual ecotourist business is recommended. Lastly, since population in general is becoming more environment conscious, an ongoing analysis of the ecotourist market would be beneficial to monitor the changing environmental trends in the tourism area. 


\section{CONCLUSION}

Ecotourism has been a subject of intense inquiry in the past few years, with much of the attention focused on the supply side namely destination attributes and management practices. The limited information available on the demand side namely the ecotourist market has been based on qualitative/descriptive studies or studies that emphasize one destination or one origin. The efforts undertaken in this study should be of value to ecotourist resource managers, planners, suppliers, marketers, or service providers at a destination. It is however, a beginning in a research area relatively untouched by ecotourist practitioners and travel researchers.

Ecotourism is promoted by many countries to economically benefit the local community and to develop tourism that is sustainable. It is seen as a viable tool for economic development and conservation of the natural resources. As a result, ecotourist business is growing and becoming more competitive. In order for the ecotourist business to position itself favorably in the global market place it has to deliver high quality service that fulfills the needs and expectations of the ecotourists.

Understanding of the service quality expectations of the ecotourists in relation to their environmental attitude and behavior, travel motivation and value dimension will help guide the positioning and repositioning strategies of 
an ecotourist business. It is important to know that an ecotourist business operator may have a product which has a quality in that it delivers the benefits sought by the ecotourists, yet the global quality evaluation may be compromised if the service quality is below expectations. Therefore, knowing the service quality expectations of the ecotourists and designing the product and services accordingly will help the service provider to position itself effectively. Although the findings of this study provide some interesting and informative insights about the ecotourists, additional research is needed to more fully understand and characterize the concept of ecotourism and service quality with its critical management and marketing implications. 


\section{BIBLIOGRAPHY}

Albrecht, D., Bultena, G., Moilberg, E., and Nowak, P. (1982). The New Environmental Paradigm Scale. Journal of Environmental Education, 13, pp. 39-43.

Anderson, C. and Zeithaml, C. P. (1984). Stage of the Product Life Cycle, Business Strategy, and Business Performance. Academv of Management Journal, 27 (March), pp. 5-24.

Armstrong, J. S., and Overton, T. (1977). Estimating Nonresponse Bias in Mail Surveys. Journal of Marketing Research, 14, August, pp. 396-402.

Arcury, T. A. (1990). Environmental Attitude and Environmental Knowledge. HumanOrganization, 49 (4), pp. 300-304.

Arcury, T. A., and Christianson, E. H. (1990). Environmental Worldview in Response to Environmental problems: Kentucky 1984 and 1988 compared. Environmentand Behavior , 22 (3), pp. 378-407.

Arcury, T. A., Johnson, T. P., and Scollay, S. J. (1986). Ecological Worldview and Knvironmental Knowledge: An Examination of the "New Environmental Paradigm." Џournal of Environmental Education, 17, pp. 35-40

Ayala, H. (1995). From Quality Product to Eco-Product: Will Fuji Set a Precedent? Tourism Managemen, 16 (1), pp. 39-47.

Ballantine, J. L., and Eagles, P.F.J. (1994). Defining Canadian Ecotourists. Journal of Sustainable Tourism, 2 (4), pp. 210-213.

Bateson, J.E.G. (1977). Do We Need Service Marketing? In Marketing Consumer Services: New Insights, Cambridge, Massachusetts: Marketing Science Institute, Report , pp. 77-115.

Berry, L.L. (1980). Services Marketing is Different. Business, 30 (May-June), pp.24-28.

Bitner, M. J., Booms, B., and Tetreault, M.S. (1990). The Service Encounter: Diagnosing Favorable and Unfavorable Incidents. Journal of Marketing, 54, pp. 71-84.

Blangy, S., and Nielsen, T. (1993). Ecotourism and Minimum Impact Policy. Annals of Tourism Research, 20 (2), pp. 357-360. 
Blocker, T. J., and Eckberg, D. L. (1989) Environmental Issues as Women's Issues: General Concerns and Local Hazards. Social Science Quarterly, 70 (3), pp. 586-593.

Boo, E. (1992). Wildlands and Human Needs. World Wildlife Fund Paper Series \# 2. pp. 14.

Boo, E. (1990). Ecotourism: The Potentials and Pitfalls, Vol. I. World Wildlife Fund. pp. 70.

Bojanic, D. C., and Rosen, L. D. (1994). Measuring Service Quality in Restaurants: An Application of the SERVQUAL Instrument. CHRIE Hospitality Research Journal, 18(1), pp. 3-15.

Boulding, W., Kalra, A., and Zeithml, V. A. (1993). A Dynamic Process of Service Quality: From Expectations to Behavioral Intentions. Journal Of Marketing Research, 30 (February), pp. 7-17.

Budowski, G. (1976). Tourism and Environmental Conservation: Conflict, Coexistence or Symbiosis? Environmental Conservation. 3 (1), pp. 2731.

Burr, P. (1991). Tourism and the Environment - Partners, not Adversaries. In Tourism: Building Credibility For a Credible Industry. Salt Lake City: Bureau of Economic and Business Research, University of Utah. pp. 59-62.

Calantone, R. J., and Mazanec, J. A. (1991). Marketing Management and Tourism. Annals of Tourism Research, 18, pp.101-119.

Caneday, L., and Zeiger, J. (1991). The Social, Economic, and Environmental Costs of Tourism to a Gaming Community as Perceived by its Residents. Journal of Travel Research, 30, pp. 45-49.

Carman, J. M. (1990). Consumer Perceptions of Service Quality: An Assessment of the SERQUAL Dimensions. Journal of Relailing, 66 (spring), pp. 33-35.

Carson, P., and J. Moulden (1991). Green is Gold: Business Talking to Business about the Environmental Revolution. Toronto: Harper Business.

Cater, E. (1993). Ecotourism in the Third World: Problems for Sustainable Tourism Develpment. Tourism Management, 14 (2), pp. 85-90. 
Ceballos-Lascurain, H. (1994). Tourism, Ecotourism, and Protected Areas. In Ecotourism: A Resource Book for Planners and Managers, edited by D. E. Hawkins and S. D. Buse. The Ecotourism Society, pp. 3-9.

Chadwick, R. A. (1994). Concepts, Definitions and Measures Used in Travel and Tourism Research. In Travel, Tourism and Hospitality Research. New York, John Wiley \& Sons, Inc. Chap. 7, pp. 65- 80.

Christensen, J. E. (1983). An Exposition of Canonical Correlation in Leisure Research. Journal of Leisure Research, 14 (4), pp. 311-322.

Crompton, John (1979). Motivations for Pleasure Travel. Annals of Tourism Research, 4, pp. 408-24.

Cronin, J. J. and Taylor, S. A. (1992). Measuring Service Quality: A Reexamination and Extension. Journal of Marketing, 56 (July), pp.55-68.

Crossley, J., and Lee, B. (1994). Ecotourists and Mass Tourist: A Difference in "Benefits Sought." In Tourism: The Economy's Silver Lining. Proceedings of the 25th TIRA Conference. Wheat Ridge, CO: TTRA, pp. 22-27.

Dann, G. (1981). Tourism Motivation: An Appraisal. Annals of Tourism Research, 8(2), pp. 187-219.

Dann, G. (1977). Anomie, Ego-ehancement and Tourism. Annals of Tourism. Research, 4, pp. 184-194.

Day, E. (1992). Conveying Service Quality Through Advertising. Journal of Service Marketing, 6 (4), pp. 53-61.

Dillman, D. A. (1978). Mail and Telephone Surveys: The Total Design Method. New York: Wiley and Sons.

Dowling, R. (1994). An Ecotourism Planning Model. In Ecotourism: A Resource Book for Planners \& Managers by D. E. Hawkins and S. D. Buse. The Ecotourism Society, pp. 99-105.

Dube, L., Renaghan, L. M., and Miller, M. (1994). Measuring Customer Satisfaction for Strategic Management. Cornell Hotel Restaurant Adminstration Quarterly 35 (1), February, pp.41. 
Dunlap, R.E. and Mertig, A.G. (1991). The Evolution of the U.S. Environmental Movement from 1970 to 1990: An Overview. Society and Natural Resources, 4, pp. 209-218.

Dunlap, R. and Scarce, R. (1991). Environmental Problems and Protection. Public Opinion Quarterly, Vol. 55 (4), pp. 651-672.

Durlap, R. E., and Van Liere, K. D. (1978). Environmental Concern: A Bibliography of Empirical Studies and Brief Appraisal of the Literature. Public Administration Series Bibliography, Monticello, 111: Vance Bibliographies.

Dunlap, R. E., and Van Liere, K. D. (1978). The New Environmental Paradigm. Journal of Environmental Education. 9, pp. 10-19

Dunlap, R. E., Van Liere, K. D., Mertig, A. G., Catton, W. R., and Howell, R. E. (1992). Measuring Endorsement of an Ecological Worldview: A Revised NEP Scale. Personal Communication.

Dunlap, R. E., and Van Liere, K. D. (1984). Commitment to the Dominant Social Paradigm and Concern for Environmental Quality. Social Science Quarterly, 65 (4), pp. 1013-1028.

Eagles, P. F. J. (1992). The Travel Motivations of Canadian Ecotourists. Journal of Travel Research, 31 (fall), pp. 3-7.

Eagles, P. F. J., and Cascagnette, J. W. (1995). “Canadian Ecotourists: Who Are They?" Tourism Recreational Research, 20 (1), pp. 22-28.

Farrell, B. H. and McLelland, R. W. (1987). Tourism and Physical Environment Research. Annals of Tourism Research, 14(1), pp. 1-16.

Fennell, D. A., and Eagles, P. J. (1990). Ecotourism in Costa Rica: A Conceptual Framework. Journal of Park and Recreation Administration, 8 (1), pp. 23-34.

Fennell, D. A., and Smale, B. (1992). Ecotourism and Natural Resource Protection. Tourism Recreational Research, 17 (1), pp. 21-32.

Fick, G.R. and Ritchie, J.R.B. (1991). Measuring Service Quality in the Travel and Tourism Industry. Lournal of Travel Research, Fall, pp. 2-9.

Frangialli, F. (1992). Tourism: Opportunity for Encounter? Threat to Local Structures? World Tourism Organization News, 5, pp. 2-3. 
Fridgen, J.D. (1990). Dimensions of Tourism. Michigan: The Educational Institute of the American Hotel \& Motel Association, pp. 159-179.

Gitelson, A. J., and Kerstetter, D. L. (1990). The Relationship Between Sociodemographic Variables, Benefits Sought and Subsequent Vacation Behavior: A Case Study. “ Journal of Travel Research, Winter, pp. 24-29.

Gunn, C. A. (1994). A Perspective on the Purpose and Nature of Tourism Research Methods. In Travel, Tourism and Hospitality Research. New York, John Wiley \& Sons, Inc. Chap. 1, pp. 3-9.

Gunn, C. (1979). Regional Strategic Planning. In Tourism Plan. Crane Russak. pp. 229-243.

Gustin, M. G., and Weaver, P. A. (1996). Are Hotels Prepared for Environmental Consumer ? CHRIE Hospitality Research Journal, 20 (2), pp. 1-14.

Hair, J. F., Anderson, A. E., Tatham, A. L. and Black, W. C. (1992). Multivariate Data Analysis with Readings, Third Edition, Macmillan Publishing Company, New York.

Hall, M. C., and McArthur, S. (1993). Ecotourism in Antartica and Sub-Antartica Islands. Tourism Management, April, pp.117-122.

Hines, J. M., Hungerford, H. R., and Tomera, A. N. (1987). Analysis and Synthesis of Research on Responsible Environmental Behavior: a MetaAnalysis. Journal of Environmental Education, 18 (2), pp. 1-8.

Hudman, L.E., and Hawkins, D.E. (1989). Tourism in Contemporary Society: An Introductory Text. New Jersey: Prentice Hall, Inc. pp 221-244.

Ingram, C. D., and Durst (1989). Nature-Oriented Tour Operators: Travel to Developing Countries. Journal of Travel Research, Fall, pp. 11-15.

Inskeep, E. (1991). Tourism Planning. New York: Van Nostrand Reinhold.

Iso-Ahola, S. E. (1982). Toward a Social Psychological Theory of Tourism Motivation: A Rejoinder. Annals of Touriam Research, 9 (2), pp. 256262

Jackson, E. L. (1987). Outdoor Recreation Participation and Views on Resource Development and Preservation. Leisure Sciences, 9, pp. 235-250. 
Kerlinger, F. N. (1986). Foundations of Behavior Research. Holt, Rinehart and Winston: New York.

Khan. M. M. (1995). Ecologically Friendly Practices of the Lodging Industry. Refereed Paper Presentation. 1995 CHRIE Conference, August 2-5, Nashville, TN. Conference Abstracts, pp. 53.

Khan. M. M., and Hawkins, D. (1995). Sustainable Tourism: An Innovative Example of Ecolodge Development in the Caribbean. Paper Presented at 1995 CHRIE Conference, August 2-5, Nashville, TN.

Khan. M. M., and Murrmann, S. (1995). Service Quality Management A Critical Factor in the Success of Hospitality Firms in the Pan-Pacific Region. Pan-Pacific Conference Proceeding.

Khan. M. M., and Uysal, M. (1995). College Students' Environmental Attitude and Behavior. Under Publication Review.

Knutson, B. J., Stevens, P., Wullaert, C., Patton, M., and Yokoyama, F. (1990). LODGSERV: A Service Quality Index for the Lodging Industry. Hospitality Research Journal, 14 (2), pp. 1-16.

Kutay, K. (1991). Ecotourism Revisited. Buzzworm: The Env January/February.

Lewis, A., and Booms, B. (1983). The Marketing Aspects of Service Quality. In Proceeding of A. M. A. Chicago: American Marketing Association, pp. 99-104.

Lindburg, K., and Hawkins, D. E. (1993). Ecotourism: A Guide for Planners and Managers. A Resource Book for Planners and Managers, The Ecotourism Society, Vermont.

Lindberg, K., and Huber, M. Jr. (1993). Economic Issues in Ecotourism Management. A Guide For Planners and Managers. The Ecotourism Society. pp. 82-115.

Liu, J.C., and Var, T. (1986). Resident Attitudes toward Tourism's Impacts in Hawaii. Annals of Tourism Research, 13-3. pp. 193-214.

Long, P.T., Perdue, R.R., and Allen, L. (1990). Rural Resident Tourism Perceptions and Attitudes by Community Level of Tourism. Journal of Travel Research, 28, pp. 3-9. 
Lovelock, C.H. (1981). Why Marketing Management Needs to be Different for Service. In Marketing of Services, J. Donnelly \& W. George, eds. Chicago, Illinois: American Marketing Association, pp. 5-9.

Lundberg, D. E. (1971). Why Tourists Travel? The Cornell Hotel and Restaurant Administration Quarterlv. February, pp. 75-81.

Maloney, M. P., and Ward, M. O. (1973). Ecology: Let's Hear it from the People. American Psychologist. 28, pp. 583-586.

Maloney, M. P., Ward, M. O., and Braucht, C. N. (1975). A Revised Scale for the Measurement of Ecological Attitudes and Knowledge. American Psychologist, 30, pp. 787-790.

Mathieson, A.. and Wall, G. (1982). Tourism: Economic, Physical, and Social Impacts, Longman. pp. 14-34

Mannell, A., and Iso-Ahola, S. (1987). Psychological Nature of Leisure and Tourism Experience. Annals of Tourism Research, 14 (3), pp. 341-329.

McIntosh, W.R., Goeldner, C.R., and Ritchie, J.R.B. (1995). Tourism: Principles, Practices, Philosophies, 7th ed. Wiley, New York.

McIntyre, G. (1993). Sustainable Tourism Development: Guide for Local Planners. World tourism Organization, pp. 39-77.

McKercher, B. (1993). The Unrecognized Threat to Tourism: Can Tourism Survive 'Sustainability'? Tourism Management, April, pp. 131-136.

Milbrath, L. W. (1984). Environmentalist Vanguard for a new society. Albany, N.Y.: State University of New York Press.

Milman, A. and Pizam, A. (1988). Social Impacts of Tourism on Central Florida. Annals of Tourism Research, 15-2. pp. 191-204.

Milni, S. (1989). The Impact of Tourism Development in Small Pacific States: An overview. New Zealand Journal of Geography April, pp. 16-21

Mohai, P. (1992). Men, Women, and the Environment: An Examination of the Gender Gap in Environmental Concern and Activism. Social and Natural Resources. 5, pp. 1-19. 
Mohai, P. and Twight, B.W. (1987). Age and Environmentalism and Elitism: An Elaboration of the Buttel Model using National Survey Evidence. Social Forces $68(4)$, pp. 798-815.

Moore, S. and Carter, B. (1993). Ecotourism in the 21st Century. Tourism Management, April, pp. 123-13.

Murray, E. J. (1964). Motivation and Emotion. Englewood Cliffs: Prentice-Hall.

Murrmann, S. K., and Suttle, C.B. (1993). Service. In VNR's Encyclopedia of Hospitality and Tourism, Khan, M. A., M. D. Olsen \& T. Var. New York: Van Nostrand Reinhold, pp. 398-406.

National Tour Association (1991). Study of Mature Adult Lifestlyles and Attitudes."

National Wildlife Foundation. (1989). Planet in Peril: A View from the Campus. Washington, D.C.

Noe, F. P., and Snow, B. (1990). The new Environmental Paradigm. Journal of Environmental Education, 21 (4), pp.20-25.

Nunnally, J. C. (1978). Psychometric Theory, McGraw-Hill, New York.

Orams, M.B. (1995). Towards a More Desirable Form of Ecotourism. Tourism Management, 16(1), pp. 3-7.

Parsuraman, A., Berry, L.L., and Zeithaml, V. (1991). Refinement and Reassessment of the SERVQUAL Scale. Journal of Retailing, 67 (winter), pp. 420-447.

Parsuraman, A., Zeithaml, V., and Berry, L.L. (1988). Servqual: A Multipleitem Scale for Measuring Customer Perceptions of Service Quality. Journal of Retailing, 64 (spring), pp. 12-40.

Parsuraman, A., Zeithaml, V., and Berry, LL (1986). Servqual: A Multiple-item Scale for Measuring Customer Perceptions of Service Quality. Working Paper. Marketing Science Institute, Cambridge, Massachusetts.

Parsuraman, A., Zeithaml, V., and Berry, L.L (1985). A Conceptual Model of Service Quality and its Implications for Future Research. Journal of Marketing 49 , pp. 41-50. 
Pearce, D. (1985). Tourism and Environmental Research: A Review. International Journal of Environmental Studies, 25, pp. 247-255.

Pearce, D.G. (1981). Tourist Development. Essex: Longman.

Pearce, D. G. and Wilson. P. M. (1995). Wildlife Viewing Tourists in New Zealand. Journal of Travel Research, fall, pp. 19- 26.

Penka, A. M. (1991). An Empirical Analysis of Environmental Attitudes and Behavioral Intentions of University Students Enrolled in Hospitality Programs. M.S. thesis. Kansas State University.

Plog, S. C. (1974). Why Destination Areas Rise and Fall in Polularity. The Cornell Hotel and Restaurant Administration Quarterly, 14 (4), pp. 55-58.

Pyo, S., Mihalik, B., and Uysal, M. (1989). Attraction Attributes and Motivations: A Canonical Carrelation Analysis. Annals of Tourism Research, 16 (2), pp. 277-282.

Ramsey, C. E., and Rickson, R. E. (1976). Environmental knowledge and attitudes. Journal of Environmental Education, 8. pp. 10-18.

Rathmell, J. (1974). Marketing in the Service Sector. Cambridge, MA: Winthrop Publishers.

Ratkai, S. K., and Smale, B. J. (1991). Regional Stability of Dimensions of Travel Motivations and Derived Market Segments of Canadians. Paper Presented at 1991 NRPA Research Symposium, Baltimore, MD October 17-20.

Reeves, C. A., and Bednar, D. A. (1995). Quality as Symphony. The Cornell Hotel and Restaurant Administration Quarterly, July, pp. 72-79.

Rosenthal, R., and Rosnow, R. L. (1984). Essentials of Behavioral Research: Methods and Data Analysis. McGraw-Hall: New York.

Ruschmann, D. M. (1992). Ecological tourism in Brazil. Tourism Management, March, pp. 125-126.

Ryel, R., and Grasse, T. (1991). Marketing Ecotourism: Attracting the Elusive Ecotourist. In Nature Tourism: Managing for the Environment. edited by Whelan, T. Washington, DC: Island Press. pp. 164-186. 
Samdahl, D. M., and Robertson, A. (1989). Social Determinants of Environmental Concern: Specification and Test of the Model. Environment and Behavior, 21 (1), pp. 57-81

Sanson, L. (1994). An Ecotourism Case Study in Sub-Antartic Islands. Annals of Tourism Research, 21 (2), pp. 334-344.

SAS Language and Procedures: Usage, Version 6, First Edition (1989), Cary, NC: SAS Institute Inc.

Schahn, J., and Holzer, E. (1990) Studies of Individual Environmental Concern: The Role of Knowledge, Gender and Background Variables. Environment and Behavior, 22 (6), pp. 767-786.

Scott, D., and Willits, F. K. (1994). Environmental Attitudes and Behavior: a Pennsylvania Survey. Environment and Behavior, 26 (2), pp. 239-260.

Shames, G.W., and Glover, G. (1989). World Class Service. Yarmouth, Michigan: Intercultural Press, Inc.

Shostack, L. (1977). Breaking Free from Product Marketing. Journal of Marketing, April, pp. 73-80.

Sonnenberg, F. K. (1989). Service Quality: Forethought, Not After Thought. The Journal of Business Strategy, September/October, pp. 54-57.

Stevens, P., Knutson, B., and Patton, M. (1995). DINESERV: A Tool for Measuring Service Quality in Restaurants. Cornell Hotel and Restaurant Administration Quarterly, April, pp. 56-60.

The Ecotourism Society. (1992). Definition and Ecotourism Statistical Fact Sheet Alexandria, VA.

The Roper Organization Inc. (1990). The Environment Public Attitudes and Individual Behavior. New York, NY.

The World Travel \& Tourism Council (WTTC). (1995) Progress and Priorities Annual Reports.

The World Travel \& Tourism Council (WTTC). (1987). Reports, pp. 22.

Trigano, G. (1984). Tourism and the Environment: The Club Mediterranean Experience. United Nations Environmental Program: Industry and Environment, 7 (1), pp. 20-21. 
United States Travel Data Center. (1991). Travel Outlook. USTDC Annual Report.

Uysal, M., Noe, F. P., and McDonald, C. D. (1994). Environmental Attitude by Trip and Visitor Characteristics. Tourism Management, 15 (4), pp. 284294.

Uysal, M. , and Hagan, A. A. (1993). Motivation of Pleasure Travel and Tourism. In M. A. Khan, M. D. Olsen, and T. Var, (Ed.), VNR's Encyclopedia of Hospitality and Tourism. Van Nostrand Reinhold, pp. 798-810.

Uysal, M., Gahan, L., and Martin, B. (1993). An Examination of Event Motivations: A Case Study. Festival Management and Event Tourism, 1, pp. 5-10.

Valentine, P.S. (1993). Ecotourism and Nature Conservation : A Definition with Some Recent Developments in Micronesia. Tourism Management, April, pp. 107-115.

Van Doren, S.C. (1983). The Future of Tourism. Journal of Physical Education, Recreation and Dance, 54 (4), pp. 27-29.

Van Liere, K. D., and Dunlap, R. E. (1980). The Social Bases of Environmental Concern: A Review of Hypotheses, Explanations and Empirical Evidence. Public Opinion Quarterly, 44, pp. 181-197.

Vickerman, S. (1980). Stimulating Tourism and Economic Growth by Featuring New Wildlife Recreation Opportunities. Proceedings of the 53rd North American Wildlife and Natural Resources Conference, pp. 414-423.

Vining, J., and Ebreo, A. (1990). What makes a recycle? A Comparison of Recyclers and Nonrecyclers. Environment and Behavior, 22 (1), pp. 5573.

Western, D. (1993). Defining Ecotourism. A Resource Book for Planners and Managers by D. E. Hawkins and S. D. Buse.The Ecotourism Society, pp. 7.

Whelan, T. (1991). Ecotourism and its Role in Sustainable Development. Nature Tourism. Washington, DC: Island Press. pp. 3-22.

Wicks, B. E., and Fesenmaier, D. A. (1993). A Comparison of Visitor and Vendor Perceptions of Service Quality at a Special Event. Festival Management and Event Tourism 1 1, pp. 19-26. 
Wight, P. (1996). North American Ecotourists: Market Profile and Trip Characteristics Iournal of Travel Research. Spring, pp. 2-10.

Wight, P. (1993a). Ecotourism: Ethics or Eco-Self? \ournal of Travel Research. Winter, pp. 3-9.

Wight, P. (1993b). Sustainable Ecotourism: Balancing Economic, Environmental and Social Goals within an Ethical Framework. The Journal of Tourism Studies, vol 4 (2), pp. 62.

Williams, E. (1991). College Students and Recycling: Their Attitudes and Behaviors. Journal of College Student Development, 32, pp. 86.

Yuan, S., and McDonald, C. D. (1990). Motivational Determinates of International Pleasure Time. Journal of Travel Research, 29 (1), pp. 42-44.

Zeithaml, V., Parasuraman, A., and Berry, B.B. (1990). In Delivering Quality Service: Balancing Customer Perceptions and Expectations. New York: The Free Press.

Ziffer, K. A. (1989). Ecotourism: The Uneasy Alliance. Washington, D.C. Conservation International and Ernst and Young. 
APPENDIX 1

NOMINAL GROUP TECHNIQUE 


\section{NOMINAL GROUP TECHNIQUE}

A nominal group technique was used to generate relevent ideas relating to the ecotourists, in St. Johns, US Virgin Islands, during an ecotourism workshop, in summer of 1995 . The nine partcipants were ecotourism society members who were attending the workshop. After a brief introduction about the rules and the ecotourist study the discussion was held. The moderator (researcher) guided the discussion and avoided leading the discussion. Notes were taken during the discussion. This section presents the information provided by the participants in the group.

\section{Rules for the Group}

1. Maximum two hours

2. Avoid moderator domination

3. Introduce the topic to be discussed

4. Only one person speak at a time - no side conservation among neighbors

5. Open discussion - anyone can make a statement

6. Body of discussion: Based on your experience at an ecotourist business what service you expects and what satisfy or dissatisfy you: 


\section{Information Provided by the Participants}

* Size of eco-lodge: minimum for 3, maximum for 100

* Detail information regarding trips, trails, interpretation

* Information and communication important events, weather

* Information should be reliable - communicate giudelines

* Environmentally friendly technology, most possible comfort with least impact on the environment

* Conservation of resources - sustainable life

* Impact of environment important - environment should get priority

* Local employees important - provide training

* Employees attire - suitable and comfortable to the employees

* Employees - friendly - courteous - glad you are there feeling-provide information

* Interaction with similar people - cultural eduactional interaction

* Experience - genuine experience - healthy environment - unpolluted setting

* Environmental education - interpretive services - contact with nature wildlife

* Activities - outdoor, culture, adventure, interaction with nature, ease of access

* Arrange trips to accomodate tourists 
* Cost of services - willing to pay more to go to ecotourist destinations

* Cost - what is spent and where the money goes is important - support local projects - supports conservation efforts - accountability of where money is going - money stay locally - donations to local community involve community

* Cultural education - indigenous communities

* Good food - local cuisine preferred - not too much alcohol

* Level of cleanliness - clean and simple - appropriate to the environment

* Decor - simple but nice - local influence 
APPENDIX 2

\section{PRE-TEST QUESTIONNAIRE}


February 21, 1996

\section{Dear Respondents:}

Enclosed please find two sections of my survey instrument for my $\mathrm{Ph} . \mathrm{D}$. research. This is only a pretest and your responses and comments will be very helpful in finalizing my questionnaire. Please read each statement carefully and check your responses. Also, please feel free to comment on clarity, comprehensibility, and cohesiveness of each statement if necessary. Your time and feedback are greatly appreciated. Please contact me if you have any questions.

Please return the completed questionnaire in the enclosed envelope at your earliest possible convenience. Thank You.

Sincerely,

\section{Maryam Khan}

Department of Hospitality \& Tourism Management

362 Wallace Hall

Virginia Tech

Blacksburg, VA 24061

(540) 552-0301 (phone)

(540) 552-7869 (fax) 


\section{SECTION 1}

This section of the questionnaire relates to your last vacation trip. For each statement, please circle $(J)$ the response that best describe how important that reason was to you when you were planning your trip. There are no right or wrong responses, we just want to know the reasons that are important to you for planning your trip.

\begin{tabular}{|c|c|c|c|c|c|}
\hline & $\begin{array}{l}\text { Very } \\
\text { Imp }\end{array}$ & $\begin{array}{c}\text { Some } \\
\text {-what } \\
\text { Imp }\end{array}$ & $\begin{array}{l}\text { Un- } \\
\text { sure }\end{array}$ & $\begin{array}{l}\text { Not- } \\
\text { Very } \\
\text { Imp }\end{array}$ & $\begin{array}{l}\text { Not-at- } \\
\text { all } \\
\text { Imp }\end{array}$ \\
\hline \multicolumn{6}{|l|}{ To get away from the demands of life } \\
\hline \multicolumn{6}{|l|}{ To relax and do nothing } \\
\hline \multicolumn{6}{|l|}{ To get away from crowds } \\
\hline \multicolumn{6}{|l|}{ To have a change from the routine } \\
\hline \multicolumn{6}{|l|}{ For a change of pace from every day life } \\
\hline \multicolumn{6}{|l|}{ Because I enjoy purposeful travel } \\
\hline \multicolumn{6}{|l|}{ Because I like to experience other cultures } \\
\hline \multicolumn{6}{|l|}{$\begin{array}{l}\text { I like to get away from commercial tourists } \\
\text { spots }\end{array}$} \\
\hline \multicolumn{6}{|l|}{ Because I like to try new foods } \\
\hline \multicolumn{6}{|l|}{ Because I am curious } \\
\hline \multicolumn{6}{|l|}{ Because I like to rediscover myself } \\
\hline \multicolumn{6}{|l|}{ I like to be daring and adventuresome } \\
\hline \multicolumn{6}{|l|}{ I like to participate in outdoor activities } \\
\hline \multicolumn{6}{|l|}{ I want to know more about the environment } \\
\hline \multicolumn{6}{|l|}{ I want to learn about the flora / the fauna } \\
\hline \multicolumn{6}{|l|}{ I like to learn more about nature } \\
\hline \multicolumn{6}{|l|}{ I like to learn about other cultures } \\
\hline \multicolumn{6}{|l|}{ I like to learn about local lifestyles } \\
\hline \multicolumn{6}{|l|}{ I like to experience unpolluted natural settings } \\
\hline \multicolumn{6}{|l|}{$\begin{array}{l}\text { I like to visit historical and cultural sites } \\
\text { /monuments }\end{array}$} \\
\hline \multicolumn{6}{|l|}{$\begin{array}{l}\text { I like to enjoy with my family } \\
\text { I like to be with my friends }\end{array}$} \\
\hline \multicolumn{6}{|l|}{ I like to be with my friends } \\
\hline \multicolumn{6}{|l|}{ I like to meet people from different cultures } \\
\hline \multicolumn{6}{|l|}{ I like to learn host country language } \\
\hline \multicolumn{6}{|l|}{ I like to be with people of similar interests } \\
\hline \multicolumn{6}{|l|}{ I like to learn about host country customs } \\
\hline I like to participate in local entertainment & & & & & \\
\hline
\end{tabular}




\section{SECTION 2}

Directions: Based on your experience as a consumer of ecotourist services, please think about the kind of ecotourist business that would deliver excellent quality of service. Think about the kind of ecotourist business with which you would be pleased to do business. Please show the extent to which you think such a business would possess the feature described by each statement. If you feel a feature is not at all essential for an excellent ecotourist business such as the one you have in mind, circle 1. If you feel a feature is absolutely essential for an excellent ecotourist business, circle 7. If your feelings are less strong, check one of the numbers in the middle.

There are no right or wrong answers -- all we are interested in is a number that truly reflects your feelings regarding ecotourist businesses that would deliver excellent quality service.

Ecotourist business is defined as a business that provides opportunities for a purposeful travel to natural environment to interact, learn, and experience other cultures, and to economically help local communities that work towards conservation and preservation of the ecosystem.

\section{Strongly Disagree}

Strongly Agree

\begin{tabular}{|l|l|l|l|l|l|l|l|}
\hline $\begin{array}{l}\text { The facilities at excellent } \\
\text { ecotourist businesses will be } \\
\text { appropriate to the environment. }\end{array}$ & 1 & 2 & 3 & 4 & 5 & 6 & 7 \\
\hline $\begin{array}{l}\text { The physical facilities at } \\
\text { excellent ecotourist businesses } \\
\text { will be visually appealing. }\end{array}$ & 1 & 2 & 3 & 4 & 5 & 6 & 7 \\
\hline $\begin{array}{l}\text { The facilities at excellent } \\
\text { ecotourist businesses will be } \\
\text { simple but comfortable. }\end{array}$ & 1 & 2 & 3 & 4 & 5 & 6 & 7 \\
\hline $\begin{array}{l}\text { Excellent ecotourist businesses } \\
\text { will have equipment that } \\
\text { minimizes environmental } \\
\text { degradation. }\end{array}$ & 1 & 2 & 3 & 4 & 5 & 6 & 7 \\
\hline $\begin{array}{l}\text { The physical facilities at } \\
\text { excellent ecotourist businesses } \\
\text { will reflect local influence. }\end{array}$ & 1 & 2 & 3 & 4 & 5 & 6 & 7 \\
\hline $\begin{array}{l}\text { The facilities at excellent } \\
\text { ecotourist businesses will be } \\
\text { environmentally safe. }\end{array}$ & 1 & 2 & 3 & 4 & 5 & 6 & 7 \\
\hline $\begin{array}{l}\text { The facilities at excellent } \\
\text { ecotourist businesses will } \\
\text { provide local entertainment. }\end{array}$ & 1 & 2 & 3 & 4 & 5 & 6 & 7 \\
\hline $\begin{array}{l}\text { The facilities at excellent } \\
\text { ecotourist businesses will be } \\
\text { located in an unpolluted } \\
\text { environment. }\end{array}$ & 1 & 2 & 3 & 4 & 5 & 6 & 7 \\
\hline $\begin{array}{l}\text { You will feel safe in your } \\
\text { transactions with excellent } \\
\text { ecotourist businesses. }\end{array}$ & 1 & 2 & 3 & 4 & 5 & 6 & 7 \\
\hline $\begin{array}{l}\text { Employees in excellent } \\
\text { ecotourist businesses will be } \\
\text { neat-appearing in local attire. }\end{array}$ & 1 & 2 & 3 & 4 & 5 & 6 & 7 \\
\hline
\end{tabular}


Strongly Disagree

Strongly Agree

\begin{tabular}{|l|c|c|c|c|c|c|c|}
\hline $\begin{array}{l}\text { Employees at excellent } \\
\text { ecotourist businesses will be } \\
\text { neat-looking in comfortable } \\
\text { attire. }\end{array}$ & 1 & 2 & 3 & 4 & 5 & 6 & 7 \\
\hline $\begin{array}{l}\text { When an excellent ecotourist } \\
\text { businesses promise to do } \\
\text { something by certain time, they } \\
\text { will do so. }\end{array}$ & 1 & 2 & 3 & 4 & 5 & 6 & 7 \\
$\begin{array}{l}\text { When a customer has a problem, } \\
\text { excellent ecotourist businesses } \\
\text { will show a sincere interest in } \\
\text { solving it. }\end{array}$ & 1 & 2 & 3 & 4 & 5 & 6 & 7 \\
\hline $\begin{array}{l}\text { The service at excellent } \\
\text { ecotourist businesses will be } \\
\text { dependable and consistent. }\end{array}$ & 1 & 2 & 3 & 4 & 5 & 6 & 7 \\
\hline $\begin{array}{l}\text { Employees in excellent } \\
\text { ecotourist businesses will tell } \\
\text { you exactly when services will } \\
\text { be performed. }\end{array}$ & 1 & 2 & 3 & 4 & 5 & 6 & 7 \\
\hline $\begin{array}{l}\text { Materials associated with the } \\
\text { service (such as pamphlets or } \\
\text { statements) will be visually } \\
\text { appealing in an excellent } \\
\text { ecotourist businesses. }\end{array}$ & 1 & 2 & 3 & 4 & 5 & 6 & 7 \\
\hline $\begin{array}{l}\text { Employes at excellent } \\
\text { ecotourist businesses will never } \\
\text { be too busy to respond to } \\
\text { customers requests. }\end{array}$ & 1 & 2 & 3 & 4 & 5 & 6 & 7 \\
\hline $\begin{array}{l}\text { Materials associated with the } \\
\text { service (such as pamphlets or } \\
\text { statements) will reflect local } \\
\text { influence in an excellent } \\
\text { ecotourist businesses. }\end{array}$ & 1 & 2 & 3 & 4 & 5 & 6 & 7 \\
\hline $\begin{array}{l}\text { Excellent ecotourist businesses } \\
\text { will perform the service right the } \\
\text { first time. }\end{array}$ & 1 & 2 & 3 & 4 & 5 & 6 & 7 \\
\hline $\begin{array}{l}\text { Behavior of employees at } \\
\text { excellent ecotourist businesses } \\
\text { will instill confidence in } \\
\text { customers. }\end{array}$ & 1 & 2 & 3 & 4 & 5 & 6 & 7 \\
\hline $\begin{array}{l}\text { Employees at excellent } \\
\text { ecotourist businesses will } \\
\text { consistently be willing to help } \\
\text { the customers. }\end{array}$ & 1 & 2 & 3 & 4 & 5 & 6 & 7 \\
\hline $\begin{array}{l}\text { Employees at excellent } \\
\text { ecotourist businesses will be } \\
\text { consistently courteous with } \\
\text { customers. }\end{array}$ & 1 & 2 & 3 & 4 & 5 & 6 & 7 \\
\hline
\end{tabular}


StronglyDisagree

\begin{tabular}{|l|c|c|c|c|c|c|c|}
\hline $\begin{array}{l}\text { Employees at excellent } \\
\text { ecotourist businesses will have } \\
\text { the knowledge to answer } \\
\text { customers' questions. }\end{array}$ & 1 & 2 & 3 & 4 & 5 & 6 & 7 \\
\hline $\begin{array}{l}\text { Excellent ecotourist businesses } \\
\text { will have operating hours } \\
\text { convenient to all their } \\
\text { customers. }\end{array}$ & 1 & 2 & 3 & 4 & 5 & 6 & 7 \\
\hline $\begin{array}{l}\text { Excellent ecotourist businesses } \\
\text { will provide necessary } \\
\text { information to customers. }\end{array}$ & 1 & 2 & 3 & 4 & 5 & 6 & 7 \\
\hline $\begin{array}{l}\text { Excellent ecotourist businesses } \\
\text { will have employees who give } \\
\text { personal attention to customers. }\end{array}$ & 1 & 2 & 3 & 4 & 5 & 6 & 7 \\
\hline $\begin{array}{l}\text { Excellent ecotourist businesses } \\
\text { will have customers' best interest } \\
\text { at heart. }\end{array}$ & 1 & 2 & 3 & 4 & 5 & 6 & 7 \\
\hline $\begin{array}{l}\text { Employees of excellent } \\
\text { ecotourist businesses will } \\
\text { anticipate customers needs and } \\
\text { wants. }\end{array}$ & 1 & 2 & 3 & 4 & 5 & 6 & 7 \\
\hline
\end{tabular}


APPENDIX 3

FINAL QUESTIONNAIRE 
To all Ecotourist Survey Participants

Dear Traveler:

Thank you for participating in our travel survey. This research is being conducted to better understand the ecotourists. There is not much information available on the ecotourists, since it is a relatively new concept in traveling. Filling out this survey will better the understanding of the ecotourists and help ecotourist businesses to improve their service quality.

To assist you in thinking about what ecotourist activities you participated in, here is a general definition of ecotourist:

Ecotourist: a traveler who engages in a purposeful travel to
natural environment to interact, learn, and experience other
cultures, and to economically help local communities that work
towards conservation and preservation of the ecosystem.

You could have participated in all or some of these activities.

There are no right or wrong answers. All responses are confidential, and will be used only in collective analyses. The number on the envelope is only for mail count.

Please answer each question as carefully as possible and return in the enclosed self-addressed postage-paid envelope AS SOON AS POSSIBLE. If you have any questions, please feel free to contact me at (000) 000-0000 (phone). Since this is a significant part of my Ph.D. research, your cooperation is highly appreciated. Thank You.

Sincerely,

Maryam Khan

Ph.D. Candidate 
SECTION 1 How many vacation trips, of at least one night, have you taken in the each of the following years?

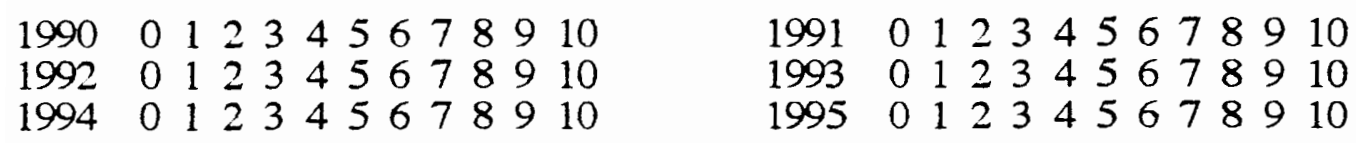

Please tell us about your vacation trip that you took in the past eighteen months. If you have taken more than one trip please refer to the one trip which included most ecotourist activities. Listed below are a series of phrases that describe ecotourist activities.

1. Please indicate the extent to which your trip fits (agree or disagree) with the following phrases. Circle the response for all the phrases that describe your experience:

\begin{tabular}{|l|c|c|c|c|c|}
\hline $\begin{array}{l}\text { Phrases that describe } \\
\text { ecotourist activities }\end{array}$ & $\begin{array}{c}\text { Strongly } \\
\text { Agree }\end{array}$ & $\begin{array}{c}\text { Moderately } \\
\text { Agree }\end{array}$ & Unsure & $\begin{array}{c}\text { Moderately } \\
\text { Disagree }\end{array}$ & $\begin{array}{c}\text { Strongly } \\
\text { Disagree }\end{array}$ \\
\hline $\begin{array}{l}\text { Experience in the natural } \\
\text { environment }\end{array}$ & 1 & 2 & 3 & 4 & 5 \\
\hline $\begin{array}{l}\text { Cultural interaction with local } \\
\text { customs }\end{array}$ & 1 & 2 & 3 & 4 & 5 \\
\hline $\begin{array}{l}\text { Social interaction with local } \\
\text { native people }\end{array}$ & 1 & 2 & 3 & 4 & 5 \\
\hline To learn about other cultures & 1 & 2 & 3 & 4 & 5 \\
\hline To interact with local community & 1 & 2 & 3 & 4 & 5 \\
\hline $\begin{array}{l}\text { To help local community } \\
\text { economically }\end{array}$ & 1 & 2 & 3 & 4 & 5 \\
\hline To see endangered species & 1 & 2 & 3 & 4 & 5 \\
\hline $\begin{array}{l}\text { To help in the protection of } \\
\text { wildlife }\end{array}$ & 1 & 2 & 3 & 4 & 5 \\
\hline $\begin{array}{l}\text { To help preserve the } \\
\text { environment }\end{array}$ & 1 & 2 & 3 & 4 & 5 \\
\hline $\begin{array}{l}\text { To experience outdoor recreation } \\
\text { (camping, hiking, birdwatching, } \\
\text { fishing, biking, canoeing, etc.) }\end{array}$ & 1 & 2 & 3 & 4 & 5 \\
\hline Photo safari & 1 & 2 & 3 & 4 & 5 \\
\hline Adventure and sports & 1 & 2 & 3 & 4 & 5 \\
\hline Other (please specify) & 1 & 2 & 3 & 4 & 5 \\
\hline
\end{tabular}

3. Was this an overseas trip? YES NO

4. Please name your destination

State and Country

5. With whom did you take this trip? (Please circle one)
a.Alone
d. Organized group/club
b. Friends
c.Family
e. Other (specify)

6. How many nights did you stay on this trip? nights 
7. What type of lodging did you stay in this trip? (Please circle one)
a.Hotel / Motel
b. Bed and breakfast
c. Huts
d. With relatives/friends
e.Campground
f.Tents
g. Cabins
h. Ranch
i. Other

8. Which of the following means of transportation did you primarily use to arrive at your destination? (Please circle only one)
a.Personal automobile
b. Rental automobile
d. Tour bus
e.Cruise ship
c. Air travel
f. Other

9. Approximately how much did you spend on this trip?

If you remember please specify the following if not, continue on:
a.Transportation: $\$$
b.Lodging: \$
c. Food: \$
d. Admission fee, activities, entertainment, etc. $\$$

10. How far in advance did you plan this trip?
a.Less than 2 weeks
c. Between 1 and 3 months
b.Between 3 and 4 weeks
e.Between 5 and 6 months
d. Between 3 and 4 months
f.More than 6 months

U.S. dollars

11. Please check the information sources that you have used in planning this trip based on their importance.

\begin{tabular}{|l|l|l|}
\hline \multicolumn{1}{|c|}{ Sources of information } & Important & $\begin{array}{c}\text { Not } \\
\text { Important }\end{array}$ \\
\hline Magazine & & \\
\hline Newspaper & & \\
\hline Television announcements & & \\
\hline Radio announcements & & \\
\hline Family and Friends & & \\
\hline Welcome and information centers & & \\
\hline Travel agent / Tour operators & & \\
\hline Netscape / Internet / World Wide Web & & \\
\hline Information received in mail & & \\
\hline Other (please specify) & & \\
\hline
\end{tabular}


SECTION 2: We would like to get your opinion on a wide range of environmental issues. For each statement, please indicate the extent to which you agree or disagree by checking the one response that best represents how you feel.

\begin{tabular}{|c|c|c|c|c|c|}
\hline & $\begin{array}{l}\text { Strongly } \\
\text { Agree }\end{array}$ & $\begin{array}{l}\text { Some- } \\
\text { what } \\
\text { Agree }\end{array}$ & Neutral & $\begin{array}{c}\text { Some- } \\
\text { what } \\
\text { Disagree }\end{array}$ & $\begin{array}{l}\text { Strongly } \\
\text { Disagree }\end{array}$ \\
\hline $\begin{array}{l}\text { We are approaching the limit of the } \\
\text { number of people the earth can support }\end{array}$ & & & & & \\
\hline $\begin{array}{l}\text { The earth has plenty of natural } \\
\text { resources if we just learn how to } \\
\text { develop them }\end{array}$ & & & & & \\
\hline $\begin{array}{l}\text { The earth is like a space ship with very } \\
\text { limited room and resources }\end{array}$ & & & & & \\
\hline $\begin{array}{l}\text { Humans have the right to modify the } \\
\text { natural enviroment to suit their needs }\end{array}$ & & & & & \\
\hline $\begin{array}{l}\text { Plants and animals have as much right } \\
\text { as humans to exist }\end{array}$ & & & & & \\
\hline $\begin{array}{l}\text { Humans were meant to rule over rest } \\
\text { of nature }\end{array}$ & & & & & \\
\hline $\begin{array}{l}\text { When humans interfere with nature it } \\
\text { of ten produces disastrous } \\
\text { consequences }\end{array}$ & & & & & \\
\hline $\begin{array}{l}\text { The balance of nature is strong enough } \\
\text { to cope with the impacts of modern } \\
\text { industrial nations }\end{array}$ & & & & & \\
\hline $\begin{array}{l}\text { The balance of nature is very delicate } \\
\text { and can be easily upset }\end{array}$ & & & & & \\
\hline $\begin{array}{l}\text { Human ingenuity will insure that we } \\
\text { do NOT make the earth unlivable }\end{array}$ & & & & & \\
\hline $\begin{array}{l}\text { Despite our special abilities humans are } \\
\text { still subject to the laws of nature }\end{array}$ & & & & & \\
\hline $\begin{array}{l}\text { Humans will eventually learn enough } \\
\text { about how nature works to be able to } \\
\text { control it }\end{array}$ & & & & & \\
\hline $\begin{array}{l}\text { Humans are severely abusing the } \\
\text { environment }\end{array}$ & & & & & \\
\hline $\begin{array}{l}\text { The so-called "ecological crisis" facing } \\
\text { humankind has been greatly } \\
\text { exaggerated }\end{array}$ & & & & & \\
\hline $\begin{array}{l}\text { If things continue on their present } \\
\text { course, we will experience a major } \\
\text { ecological catastrophe }\end{array}$ & & & & & \\
\hline
\end{tabular}


SECTION 3 For each statement listed below, please check $(\neg$ ) one response that best describes you.

\begin{tabular}{|l|l|l|l|l|}
\hline & Always & $\begin{array}{l}\text { Some } \\
\text { time }\end{array}$ & Rarely & Never \\
\hline Do you practice recycling of cans & & & & \\
\hline Do you practice recycling of paper & & & & \\
\hline Do you practice recycling of glass & & & & \\
\hline Do you practice recycling of plastic & & & & \\
\hline Do you practice recycling of oil & & & & \\
\hline $\begin{array}{l}\text { Do you consider participation in environmental } \\
\text { related protests }\end{array}$ & & & & \\
\hline $\begin{array}{l}\text { Do you consider giving money to environmental } \\
\text { organizations }\end{array}$ & & & & \\
\hline $\begin{array}{l}\text { Do you consider doing volunteer work for } \\
\text { environmental groups }\end{array}$ & & & & \\
\hline $\begin{array}{l}\text { Do you consider writing letters to officials } \\
\text { regarding environmental issues }\end{array}$ & & & & \\
\hline $\begin{array}{l}\text { Do you consider being more environmentally } \\
\text { friendly if you were the one incharge of policies } \\
\text { and procedures }\end{array}$ & & & & \\
\hline $\begin{array}{l}\text { Do you avoid purchasing products from } \\
\text { companies that pollute environment }\end{array}$ & & & & \\
\hline $\begin{array}{l}\text { Do you avoid purchasing of certain foods because } \\
\text { of the chemicals used }\end{array}$ & & & & \\
\hline Do you buy reduced packaging products & & & & \\
\hline $\begin{array}{l}\text { Do you buy products made of recycled materials } \\
\text { whenever possible }\end{array}$ & & & & \\
\hline Do you avoid using aerosol spray cans & & & & \\
\hline Do you have concern for the environment & & & & \\
\hline $\begin{array}{l}\text { Do you patronize businesses that have } \\
\text { environmentally friendly practices }\end{array}$ & & & & \\
\hline $\begin{array}{l}\text { Do you think businesses are more } \\
\text { environmentally friendly now than ten years back }\end{array}$ & & & & \\
\hline $\begin{array}{l}\text { Do you want to know more about the } \\
\text { environment }\end{array}$ & & & & \\
\hline $\begin{array}{l}\text { Do you think environmental issues should be } \\
\text { given number one priority }\end{array}$ & & & & \\
\hline
\end{tabular}


SECTION 4 For each statement, please check ( $\lambda$ the response that best describe how important that reason was to you when you were planning this trip.

\begin{tabular}{|c|c|c|c|c|c|}
\hline & $\begin{array}{c}\text { Very } \\
\text { Important }\end{array}$ & $\begin{array}{c}\text { Some- } \\
\text { what } \\
\text { Important }\end{array}$ & Unsure & $\begin{array}{c}\text { Not- } \\
\text { Very } \\
\text { Important }\end{array}$ & $\begin{array}{l}\text { Not-at-all } \\
\text { Important }\end{array}$ \\
\hline \multicolumn{6}{|l|}{$\begin{array}{l}\text { To get away from the } \\
\text { demands of life }\end{array}$} \\
\hline \multicolumn{6}{|l|}{ To relax and do nothing } \\
\hline \multicolumn{6}{|l|}{ To get away from crowds } \\
\hline \multicolumn{6}{|l|}{$\begin{array}{l}\text { To have a change from the } \\
\text { routine }\end{array}$} \\
\hline \multicolumn{6}{|l|}{$\begin{array}{l}\text { For a change of pace from } \\
\text { every day life }\end{array}$} \\
\hline \multicolumn{6}{|l|}{$\begin{array}{l}\text { To get away from } \\
\text { commercial tourists spots }\end{array}$} \\
\hline \multicolumn{6}{|l|}{ To enjoy purposeful travel } \\
\hline \multicolumn{6}{|l|}{ To try new foods } \\
\hline \multicolumn{6}{|l|}{ Because I am curious } \\
\hline \multicolumn{6}{|l|}{ To rediscover myself } \\
\hline \multicolumn{6}{|l|}{$\begin{array}{l}\text { To be daring and } \\
\text { adventuresome }\end{array}$} \\
\hline \multicolumn{6}{|l|}{$\begin{array}{l}\text { To participate in outdoor } \\
\text { activities }\end{array}$} \\
\hline \multicolumn{6}{|l|}{$\begin{array}{l}\text { To know more about the } \\
\text { environment }\end{array}$} \\
\hline \multicolumn{6}{|l|}{$\begin{array}{l}\text { To learn about the flora / the } \\
\text { fauna }\end{array}$} \\
\hline \multicolumn{6}{|l|}{ To learn more about nature } \\
\hline \multicolumn{6}{|l|}{$\begin{array}{l}\text { To learn about other } \\
\text { cultures }\end{array}$} \\
\hline \multicolumn{6}{|l|}{$\begin{array}{l}\text { To learn about local } \\
\text { lifestyles }\end{array}$} \\
\hline $\begin{array}{l}\text { To experience unpolluted } \\
\text { natural settings }\end{array}$ & & & & & \\
\hline
\end{tabular}




\begin{tabular}{|l|l|l|l|l|l|}
\hline & $\begin{array}{c}\text { Very } \\
\text { Important }\end{array}$ & $\begin{array}{c}\text { Some- } \\
\text { what } \\
\text { Important }\end{array}$ & Unsure & $\begin{array}{c}\text { Not-Very } \\
\text { Important }\end{array}$ & $\begin{array}{c}\text { Not-at-all } \\
\text { Important }\end{array}$ \\
\hline $\begin{array}{l}\text { To visit historical and } \\
\text { cultural sites/ monuments }\end{array}$ & & & & & \\
\hline To be with my family & & & & & \\
\hline To be with my friends & & & & & \\
\hline $\begin{array}{l}\text { To meet people from } \\
\text { different cultures }\end{array}$ & & & & & \\
\hline $\begin{array}{l}\text { To learn host country } \\
\text { language }\end{array}$ & & & & & \\
\hline $\begin{array}{l}\text { To be with people of } \\
\text { similar interests }\end{array}$ & & & & & \\
\hline $\begin{array}{l}\text { Ilike to participate in local } \\
\text { entertainment }\end{array}$ & & & & & \\
\hline To be by myself & & & & & \\
\hline
\end{tabular}

SECTION 5 Directions: Based on your experience as a consumer of ecotourist services, please think about the kind of ecotourist business that would deliver excellent quality of service. Think about the kind of ecotourist business with which you would be pleased to do business. Please show the extent to which you think such a business would possess the feature described by each statement. If you feel a feature is not at all essential for an excellent ecotourist business such as the one you have in mind, circle 1. If you feel a feature is absolutely essential for an excellent ecotourist business, circle 7. If your feelings are less strong, check one of the numbers in the middle.

Ecotourist business is defined as a business that provides opportunities for a purposeful travel to natural environment to interact, learn, and experience other cultures, and to economically help local communities that work towards conservation and preservation of the ecosystem.

STRONGLY DISAGREE-..-STRONGLY AGREE

\begin{tabular}{|l|c|c|c|c|c|c|c|}
\hline $\begin{array}{l}\text { Excellent ecotourist businesses will have } \\
\text { equipment that minimizes } \\
\text { environmental degradation. }\end{array}$ & 1 & 2 & 3 & 4 & 5 & 6 & 7 \\
\hline $\begin{array}{l}\text { The facilities at excellent ecotourist } \\
\text { businesses will be appropriate to the } \\
\text { environment. }\end{array}$ & 1 & 2 & 3 & 4 & 5 & 6 & 7 \\
\hline
\end{tabular}


STRONGLY DISAGREE-.--STRONGLY AGREE

\begin{tabular}{|l|l|l|l|l|l|l|l|}
\hline $\begin{array}{l}\text { The facilities at excellent ecotourist } \\
\text { businesses will be environmentally safe. }\end{array}$ & 1 & 2 & 3 & 4 & 5 & 6 & 7 \\
\hline $\begin{array}{l}\text { The physical facilities at excellent } \\
\text { ecotourist businesses will be visually } \\
\text { appealing. }\end{array}$ & 1 & 2 & 3 & 4 & 5 & 6 & 7 \\
\hline $\begin{array}{l}\text { The facilities at excellent ecotourist } \\
\text { businesses will be located in an } \\
\text { unpolluted environment. }\end{array}$ & 1 & 2 & 3 & 4 & 5 & 6 & 7 \\
\hline $\begin{array}{l}\text { The physical facilities at excellent } \\
\text { ecotourist businesses will reflect local } \\
\text { influence. }\end{array}$ & 1 & 2 & 3 & 4 & 5 & 6 & 7 \\
\hline $\begin{array}{l}\text { The facilities at excellent ecotourist } \\
\text { businesses will provide local } \\
\text { entertainment. }\end{array}$ & 1 & 2 & 3 & 4 & 5 & 6 & 7 \\
\hline $\begin{array}{l}\text { Employees of excellent ecotourist } \\
\text { businesses will be neat-appearing in local } \\
\text { attire. }\end{array}$ & 1 & 2 & 3 & 4 & 5 & 6 & 7 \\
\hline $\begin{array}{l}\text { Employees of excellent ecotourist } \\
\text { businesses will be neat-looking in } \\
\text { comfortable attire. }\end{array}$ & 1 & 2 & 3 & 4 & 5 & 6 & 7 \\
\hline $\begin{array}{l}\text { Materials associated with the service } \\
\text { (such as pamphlets or statements) will be } \\
\text { visually appealing in excellent ecotourist } \\
\text { businesses. }\end{array}$ & 1 & 2 & 3 & 4 & 5 & 6 & 7 \\
\hline $\begin{array}{l}\text { Materials associated with the service } \\
\text { (such as pamphlets or statements) will } \\
\text { reflect local influence in excellent } \\
\text { ecotourist businesses. }\end{array}$ & 1 & 2 & 3 & 4 & 5 & 6 & 7 \\
\hline
\end{tabular}

STRONGLY DISAGREE---STRONGLY AGREE

\begin{tabular}{|l|c|c|c|c|c|c|c|}
\hline $\begin{array}{l}\text { Employees of excellent ecotourist } \\
\text { businesses will tell you exactly when } \\
\text { services will be performed. }\end{array}$ & 1 & 2 & 3 & 4 & 5 & 6 & 7 \\
\hline $\begin{array}{l}\text { Employees of excellent ecotourist } \\
\text { businesses will give prompt service to } \\
\text { customers. }\end{array}$ & 1 & 2 & 3 & 4 & 5 & 6 & 7 \\
\hline $\begin{array}{l}\text { Employees at excellent ecotourist } \\
\text { businesses will always be willing to help } \\
\text { customers. }\end{array}$ & 1 & 2 & 3 & 4 & 5 & 6 & 7 \\
\hline $\begin{array}{l}\text { Employees of excellent ecotourist } \\
\text { businesses will never be too busy to } \\
\text { respond to customers' requests. }\end{array}$ & 1 & 2 & 3 & 4 & 5 & 6 & 7 \\
\hline
\end{tabular}


STRONGLY DISAGREE--.-STRONGLYAGREE

\begin{tabular}{|l|l|l|l|l|l|l|l|}
\hline $\begin{array}{l}\text { When excellent ecotourist businesses } \\
\text { promise to do something by certain time, } \\
\text { they will do so. }\end{array}$ & 1 & 2 & 3 & 4 & 5 & 6 & 7 \\
\hline $\begin{array}{l}\text { When a customer have a problem, } \\
\text { excellent ecotourist businesses will show } \\
\text { a sincere interest in solving it. }\end{array}$ & 1 & 2 & 3 & 4 & 5 & 6 & 7 \\
\hline $\begin{array}{l}\text { Excellent ecotourist businesses will } \\
\text { perform the service right the first time. }\end{array}$ & 1 & 2 & 3 & 4 & 5 & 6 & 7 \\
\hline $\begin{array}{l}\text { Excellent ecotourist businesses will } \\
\text { provide their services at the time they } \\
\text { promise to do so. }\end{array}$ & 1 & 2 & 3 & 4 & 5 & 6 & 7 \\
\hline $\begin{array}{l}\text { Excellent ecotourist businesses will insist } \\
\text { on error-free records. }\end{array}$ & 1 & 2 & 3 & 4 & 5 & 6 & 7 \\
\hline
\end{tabular}

STRONGLY DISAGREE---STRONGLY AGREE

\begin{tabular}{|l|l|l|l|l|l|l|l|}
\hline $\begin{array}{l}\text { Excellent ecotourist businesses will give } \\
\text { customers individual attention. }\end{array}$ & 1 & 2 & 3 & 4 & 5 & 6 & 7 \\
\hline $\begin{array}{l}\text { Excellent ecotourist businesses will have } \\
\text { operating hours convenient to all their } \\
\text { customers. }\end{array}$ & 1 & 2 & 3 & 4 & 5 & 6 & 7 \\
\hline $\begin{array}{l}\text { Excellent ecotourist businesses will have } \\
\text { employees who give customers personal } \\
\text { attention. }\end{array}$ & 1 & 2 & 3 & 4 & 5 & 6 & 7 \\
\hline $\begin{array}{l}\text { Excellent ecotourist businesses will have } \\
\text { customers' best interests at heart. }\end{array}$ & 1 & 2 & 3 & 4 & 5 & 6 & 7 \\
\hline $\begin{array}{l}\text { Employees of excellent ecotourist } \\
\text { businesses will understand the specific } \\
\text { needs of their customers. }\end{array}$ & 1 & 2 & 3 & 4 & 5 & 6 & 7 \\
\hline
\end{tabular}

STRONGLY DISAGREE......-STRONGLY AGREE

\begin{tabular}{|l|c|c|c|c|c|c|c|}
\hline $\begin{array}{l}\text { Employees of excellent ecotourist } \\
\text { businesses will have the knowledge to } \\
\text { answer customer questions. }\end{array}$ & 1 & 2 & 3 & 4 & 5 & 6 & 7 \\
\hline $\begin{array}{l}\text { The behavior of employees of excellent } \\
\text { ecotourist businesses will instill } \\
\text { confidence in customers. }\end{array}$ & 1 & 2 & 3 & 4 & 5 & 6 & 7 \\
\hline $\begin{array}{l}\text { Customers of excellent ecotourist } \\
\text { businesses will feel safe in their } \\
\text { transactions. }\end{array}$ & 1 & 2 & 3 & 4 & 5 & 6 & 7 \\
\hline $\begin{array}{l}\text { Employees of excellent ecotourist } \\
\text { businesses will be consistently courteous } \\
\text { with customers. }\end{array}$ & 1 & 2 & 3 & 4 & 5 & 6 & 7 \\
\hline $\begin{array}{l}\text { Excellent ecotourist businesses will } \\
\text { provide necessary information to } \\
\text { customers. }\end{array}$ & 1 & 2 & 3 & 4 & 5 & 6 & 7 \\
\hline
\end{tabular}


STRONGLY DISAGREE-.-.-.-.STRONGLY AGREE

\begin{tabular}{|l|l|l|l|l|l|l|l|}
\hline $\begin{array}{l}\text { Excellent ecotourist business services } \\
\text { costs more than regular tourist } \\
\text { services. }\end{array}$ & 1 & 2 & 3 & 4 & 5 & 6 & 7 \\
\hline $\begin{array}{l}\text { Customers purchasing excellent } \\
\text { ecotourist services do not expect to } \\
\text { pay more than regular tourism } \\
\text { services. }\end{array}$ & 1 & 2 & 3 & 4 & 5 & 6 & 7 \\
\hline $\begin{array}{l}\text { Excellent ecotourist businesses uses } \\
\text { part of its profits to educate the } \\
\text { customers and locals about } \\
\text { environmental issues. }\end{array}$ & 1 & 2 & 3 & 4 & 5 & 6 & 7 \\
\hline $\begin{array}{l}\text { Excellent ecotourist businesses } \\
\text { provide environmentally friendly } \\
\text { services at a reasonable cost. }\end{array}$ & 1 & 2 & 3 & 4 & 5 & 6 & 7 \\
\hline $\begin{array}{l}\text { Excellent ecotourist businesses uses } \\
\text { part of its profits to benefit } \\
\text { community projects. }\end{array}$ & 1 & 2 & 3 & 4 & 5 & 6 & 7 \\
\hline
\end{tabular}

SECTION 6 We would like to get to know you better.

All information will be strictly confidential.

1. Your present age
a. Less than 20 years old
b. From 20 to 24 years old
e. From 45 to 54 years old
c. From 25 to 34 years old
d. From 35 to 44 years old
f. From 55 to 64 years old
g. From 65 to 74 years old
h. Over 75 years old

2. Your education level

Grade School

High School College

Graduate School

$\begin{array}{lllllllllllllllllllll}1 & 2 & 3 & 4 & 5 & 6 & 7 & 8 & 9 & 10 & 11 & 12 & 13 & 14 & 15 & 16 & 17 & 18 & 19 & 20 & 21+\end{array}$

3. Gender a. Male __ b. Female

4. Your marital status
a. Never married
b. Married
c. Divorced / separated
d. Widowed

5. Your household consists of...
a. Single living alone
b. Married couple without children
c. Married couple with children
d. Middle-aged couple with all children living elsewhere
e. Retired couple (at least one spouse retired).
f. Single with children
g. Other (specify) 
6. Your approximate household income
a. Under $\$ 19,000$
b. $\$ 20,000$ to $\$ 29,000$
c. $\$ 30,000$ to $\$ 39,000$
d. $\$ 40,000$ to $\$ 49,000$
e. $\$ 50,000$ to $\$ 59,000$

7. Your State:

f. $\$ 60,000$ to $\$ 69,000$

g. $\$ 70,000$ to $\$ 79,000$

h. $\$ 80,000$ to $\$ 89,000$

i. $\$ 90,000$ to $\$ 99,000$

j. Over 100,000

Zip code:

8. The community in which you live now
a. Rural
b. Small town
c. City
d. Suburban
e. Other (specify)

9. Your Occupation
a. Homemaker
b. Professional/Technical
c. Executive/Administrator
d. Middle Management
e. Sales/Marketing
f. Clerical
g. Laborer/worker
h. Student
i. Self employed/Business Owner
g. Teacher
h. Retired
i. Other (specify)

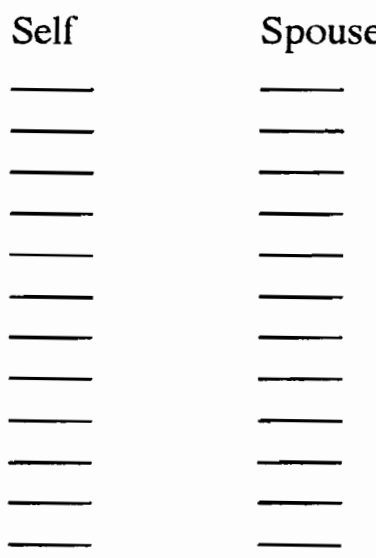

10. Your ethnic background
a. Black
b. White
c. Asian,
d. Native American
e. Other (specify)

11. COMMENTS: If there is anything esle you would like to tell us about your participation in ecotourist activities, please feel free to do so on this last page.

Please return the completed survey using the postage paid return envelope THANK YOU FOR YOUR TIME AND COOPERATION 
This research project was awarded:
National Tour Foundation's Luray Caverns Graduate Research Grant

YOUR PARTICIPATION IS EXTREMELY HELPFUL FOR THIS RESEARCH

THERE ARE NO RIGHT OR WRONG ANSWERS

YOUR OPINION COUNTS 


\section{APPENDIX 4}

COVER LETTER, ENVELOPE, AND LOTTERY COUPONS 
May 20, 1996

\section{Dear Traveler.}

Please find enciosed a survey that is part of my Ph.D. research dissertation. The purpose of the study is to better understand the phenomenon of travel and natural environment. Your participation in this research project is greatly appreciated.

For your time and support, I am offering you the possibility of winning:

1) Seven nights stay at award winning Maho Bay Resort in St. John, US Virgin Islands for two, between May 1 to December 14 1996. I am sorry the package does not include airfare, but it does offer a chance to experience a pristine natural environment.

OR

2) A day hike for two on the Island of Hawaii, which includes lunch and beverages, equipment, guide services, and of course opportunity to walk in the footsteps of the Hawaiians of old.

The winners will be selected by lottery drawing. In order to be included in the drawing please complete the survey and fill out the attached tickets with your name, address, and phone number. Please do not write your name on the survey to maintain anonymity and your name on the tickets will be used only for the package drawing.

I just can't thank you enough for your time and cooperation to help me complete this research. Once again thank you.

Sincerely,

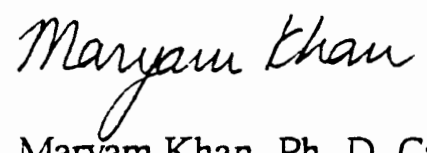

Maryam Khan, Ph. D. Candidate

1995 Luray Cavern Graduate Research Award Recipient 


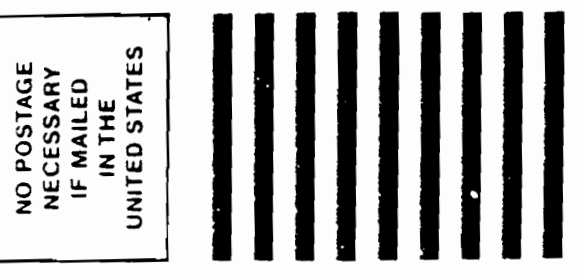
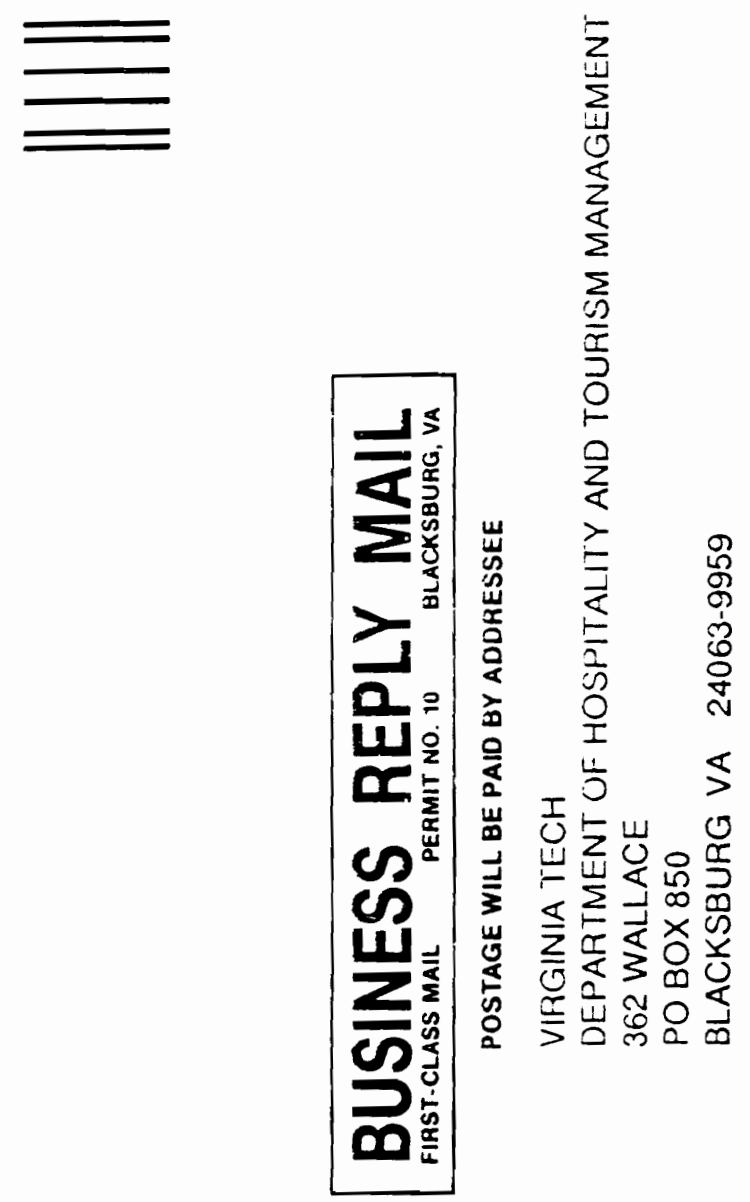

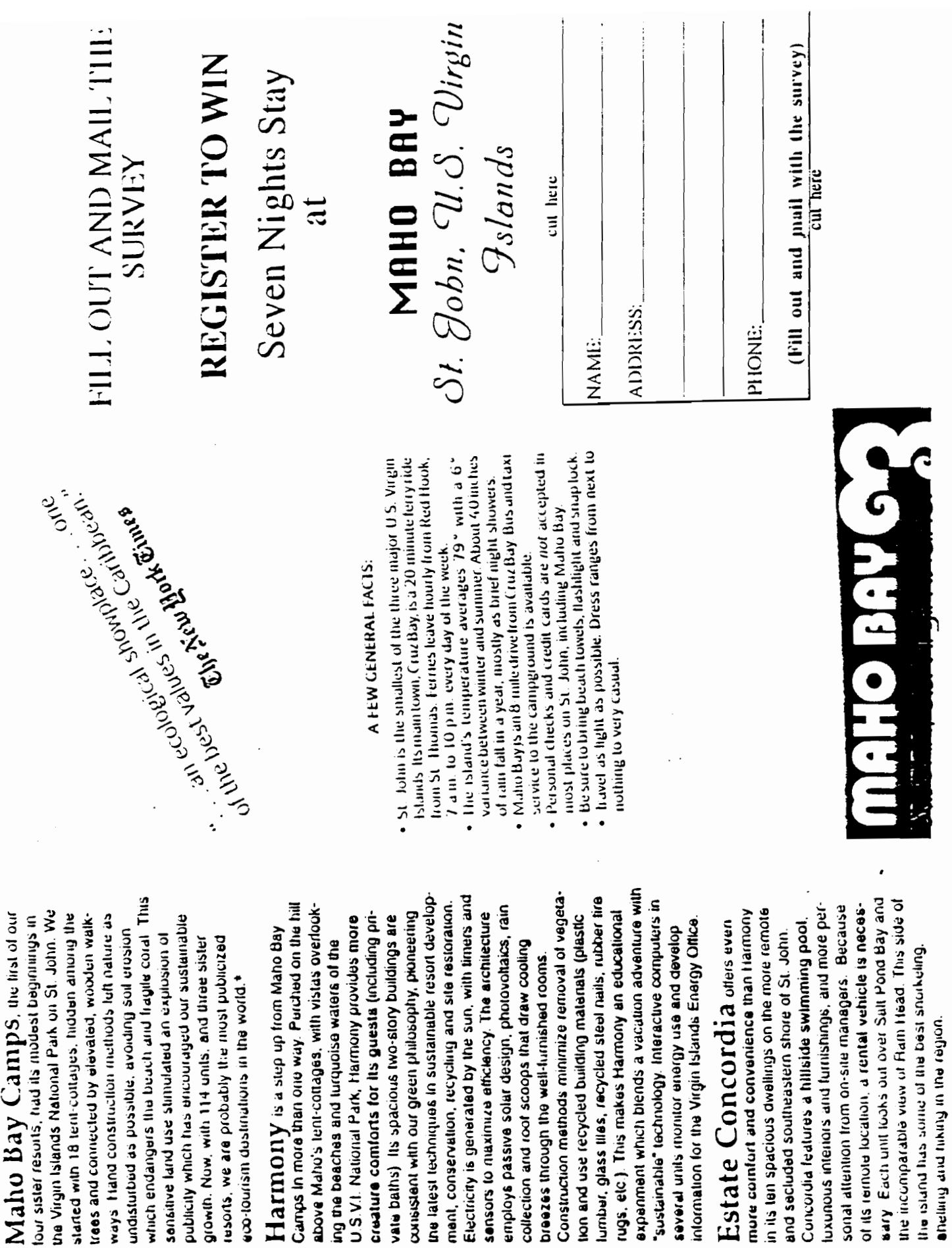


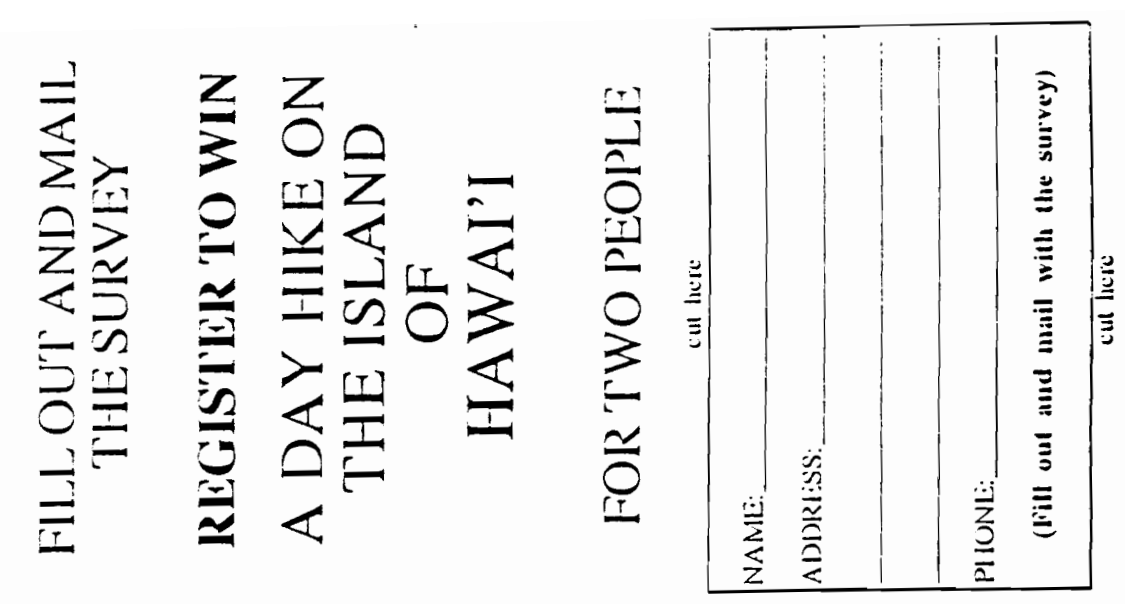

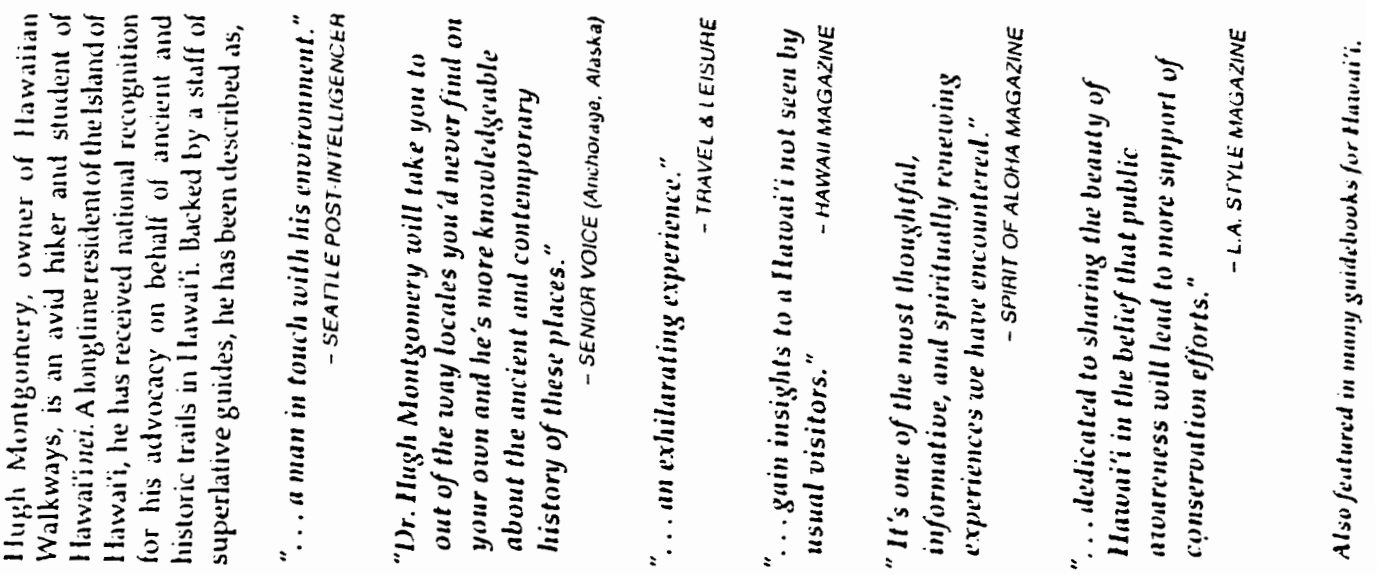

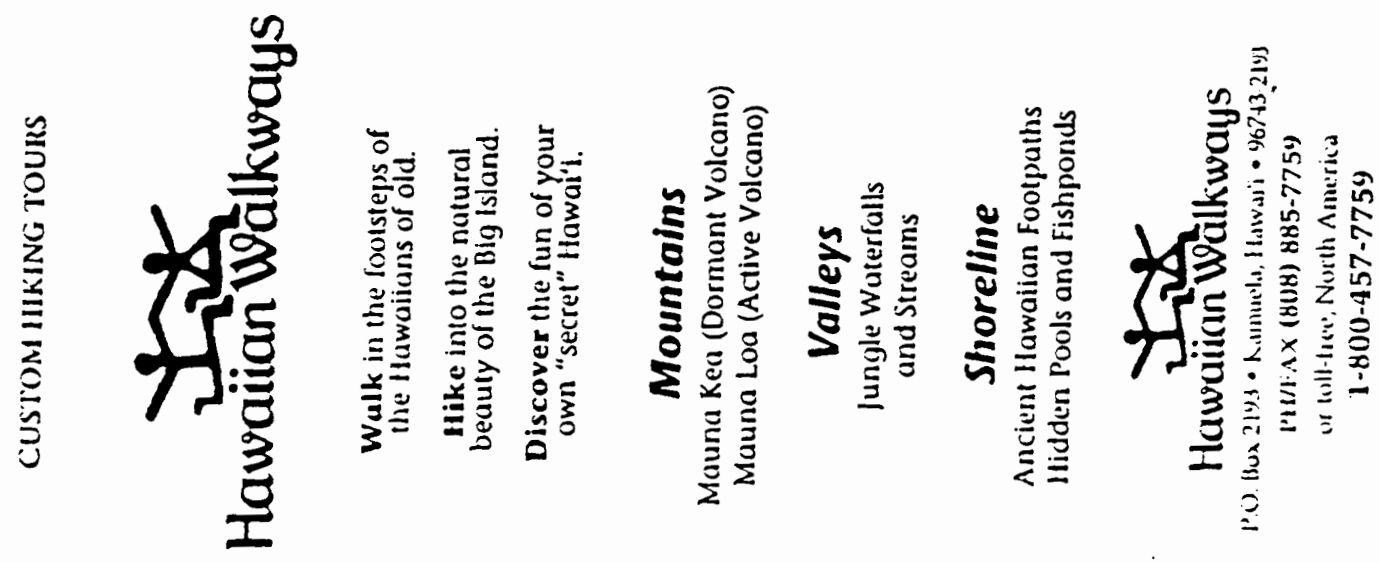


APPENDIX 5

\section{REMINDER LETTER}




\section{REMINDER}

\section{Dear Survey Respondent:}

About two weeks back, a survey relating to travel and the natural environment was mailed to you.

Since it was a blind mailing there is no way to determine whether or not you have responded. If you have already completed the survey and returned, I appreciate your thoughtfulness. If you have mailed the coupon along with the survey, your name will be included in the drawing.

If not, please take some time to fill and return the survey, since your response is very important to the success of this research and completion of my Ph.D. dissertation. Your participation is extremely valuable and I cannot thank you enough.

In case you have not received my survey, please let me know, I will mail one immediately. Phone \# (540) 552-0301;

Fax \# (540) 552-7869.

Thank you for your help in completion of my Ph.D. dissertation.

sincerely,

Haryan khan

Maryagh Khan, Ph.D. Candidate

Department of Hospitality \& Tourism Management

362 Wallace Hall

Virginia Polytechnic Institute and State University

Blacksburg, VA 24061-0429 
APPENDIX 6

EARLY RESPONSES AND LATE RESPONSES 


\section{COMPARISONS OF EARLY RESPONSES AND LATE RESPONSES}

Selected Behavior Variables

\begin{tabular}{lcccc}
\hline & $\begin{array}{c}\text { Early } \\
\text { Responses } \\
(\mathrm{n}=35)\end{array}$ & $\begin{array}{c}\text { Late } \\
\text { Responses } \\
(\mathrm{n}=36)\end{array}$ & t-value & Sig. \\
\hline Behavior: & 1.20 & 1.09 & 1.28 & .21 \\
Cans & 1.35 & 1.23 & .72 & .47 \\
Paper & 1.60 & 1.09 & 3.04 & .004 \\
Glass & 1.55 & 1.35 & 1.56 & .25 \\
Plastic & & & & \\
Attitude: & & & & \\
\hline Nep12 & 3.52 & 3.73 & -.80 & .43 \\
Nep13 & 1.69 & 1.76 & -1.17 & .79 \\
Nep14 & 3.8 & 4.14 & -.75 & .24 \\
Nep15 & 1.91 & 2.09 & -.21 & .45 \\
Motivation: & & & & \\
\hline Mot1 & 1.91 & 1.97 & -.21 & .83 \\
Mot2 & 3.55 & 3.24 & 1.03 & .30 \\
Mot3 & 2.28 & 2.29 & -.03 & .97 \\
Mot4 & 1.88 & 1.60 & 1.22 & .22 \\
Service Exp: & & & & \\
Serv1 & & & & .03 \\
Serv2 & 6.82 & 6.30 & 2.20 & .14 \\
Serv3 & 6.77 & 6.47 & 1.48 & .09 \\
Serv4 & 6.74 & 6.36 & 1.70 & \\
\hline
\end{tabular}

Selected Demographic Variables

\begin{tabular}{lcccc}
\hline & $\begin{array}{c}\text { Earty } \\
\text { Responses } \\
(\mathrm{n}=35)\end{array}$ & $\begin{array}{c}\text { Late } \\
\text { Responses } \\
(\mathrm{n}=36)\end{array}$ & $\begin{array}{c}\text { chi- } \\
\text { square }\end{array}$ & Sig. \\
\hline Age (vears) & $\%$ & & 6.28 & .09 \\
less than 25 & 2.8 & .3 & & \\
$25-44$ & 18.3 & 19.7 & & \\
$45-64$ & 18.3 & 28.0 & .410 & .52 \\
$65+$ & 9.8 & 2.8 & & \\
Gender & & & & \\
\hline Male & 16.9 & 21.1 & & \\
Female & 32.4 & 29.6 & & \\
\hline
\end{tabular}


VITA 


\section{VITA}

\section{MARYAM M. KHAN}

Maryam M. Khan was born in Hyderabad, India. She graduated from Osmania University with Bachelor of Arts in American Literature, Political Science, and Economics. She has a Master of Science degree from University of Illinois at Urbana-Champaign in Human Resources. Her professional experience includes research and teaching at University of Illinois and Virginia Tech as Instructor, Research Associate and Teaching Assistant. She taught Travel and Tourism Management course in the Department of Hospitality and Tourism Management at Virginia Tech. She also worked as a Graduate Administrative Assistant in recruitment and outreach activities. As Research Associate, she developed data base for corporate marketing at Hotel Roanoke.

She was the President of the Travel and Tourism Research Association chapter at Virginia Tech. She has received several awards including Outstanding Service Award and Luray Caverns Research Grant. Her dissertation research was awarded a research grant by the National Tour Foundation. She received the Certificate of Excellence in Travel Education awarded by the National Tour Foundation. 
She is a co-author of the book "Hospitality and Tourism Management: The Profession of the Next Century." She has presented several papers in national and international meetings related with Hospitality and Tourism research. She completed continuing education courses on Operating an Ecolodge and Ecolodge Planning and Sustainable Design offered by the George Washington University's School of Business and Public Management. She is a member of Kappa Omicron $\mathrm{Nu}$ and Phi Sigma Alpha Psi. She holds memberships in several professional associations.

She has travel extensively to different parts of the world including England, France, Switzerland, Holland, Germany, Italy, Saudi Arabia, India, Australia, New Zealand, Canada, Mexico, Virgin Islands, Japan, Singapore, Malaysia and Bahamas. 